\title{
The PERMA-Profiler: A brief multidimensional measure of flourishing
}

\author{
Julie Butler · Margaret L. Kern
}

\begin{abstract}
In the book Flourish (2011), Seligman defined wellbeing in terms of five pillars: Positive emotion, Engagement, Relationships, Meaning, and Accomplishment, or PERMA. We developed the PERMA-Profiler as a brief measure of PERMA. We first compiled hundreds of theoretically relevant items. Three studies $(N=7,188)$ reduced, tested, and refined items, resulting in a final set of 15 questions (three items per PERMA domain). Eight additional filler items were added, which assess overall wellbeing, negative emotion, loneliness, and physical health, resulting in a final 23item measure. A series of eight additional studies $(N=31,966)$ were conducted to test the psychometrics of the measure. The PERMA-Profiler demonstrates acceptable model fit, internal and cross-time consistency, and evidence for content, convergent, and divergent validity. Scores are reported visually as a profile across domains, reflecting the multidimensional nature of flourishing. The PERMA-Profiler adds to the toolbox of wellbeing measures, allowing individuals to monitor their wellbeing across multiple psychosocial domains.
\end{abstract}

Keywords: wellbeing, flourishing, assessment, measure development, positive psychology

\section{Introduction}

A growing number of individuals, organizations, and policy makers worldwide are focusing on wellbeing, and with good reason. Evidence indicates that subjective wellbeing, life satisfaction, optimism, happiness, and other positive constructs are associated with numerous desirable outcomes, including lower rates of divorce, greater educational and occupational success, stronger friendships, and better physical health (e.g., Diener \& Chan, 2011; Huppert, 2009; Lyubomirsky, King, \& Diener, 2005). Understanding and supporting wellbeing is increasingly envisioned as an interdisciplinary issue that should be addressed at multiple levels within a system, including individuals, organizations, communities, and nations (Huppert \& So, 2013). A key element in the promotion of wellbeing is the need to measure and document levels and changes in wellbeing at individual, community, and national levels. We present the development, psychometrics, and potential applications of one such measure: the PERMA-Profiler.

\section{Defining wellbeing}

Definitions and theories of wellbeing abound (see Forgeard et al., 2011 and Hone, Jarden, Schofield, \& Duncan, 2014 for reviews). Wellbeing can be defined and measured objectively (e.g.,

Margaret L. Kern

University of Melbourne \&

University of Pennsylvania

margaret.kern@unimelb.edu.au

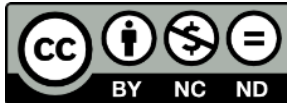


sufficient resources to meet basic needs, opportunities for education, lack of environmental pollutants) or subjectively; we focus here on the subjective side. In the literature, terms such as "happiness", "subjective wellbeing", "thriving", and "flourishing" are often used interchangeably, and we use these terms interchangeably here.

Some theories focus on emotion (hedonic wellbeing), some emphasize eudaimonic elements (i.e., the good life), and others blend hedonic and eudaimonic domains (Ryan \& Deci, 2001). For example, over 30 years ago, Diener (1984) noted that subjective wellbeing includes affective and cognitive elements. Ryff and Keyes (1995) define psychological wellbeing across six domains (self-acceptance, positive relationships with others, autonomy, environmental mastery, purpose in life, personal growth). Keyes (2002) suggests flourishing requires "symptoms" of high emotional, psychological, and social wellbeing. Seligman's (2011) PERMA model advocates that flourishing arises from five wellbeing pillars (positive emotion, engagement, relationships, meaning, accomplishment). Huppert and So (2013) define 10 components of flourishing that are the opposite of the main symptoms of depression and anxiety (competence, emotional stability, engagement, meaning, optimism, positive emotion, positive relationships, resilience, self-esteem, vitality). Wong (2011) proposes that hedonic, prudential (being fully engaged in life), eudaimonic, and chaironic (feeling blessed) types of happiness all contribute to an overall sense of subjective wellbeing, but come together in different ways depending on the person, circumstances, and context. Through a quantitative analysis of studies with topics relevant to positive psychology, Rusk and Waters (2015) empirically derived a five-domain model of positive functioning (comprehension and coping, attention and awareness, emotions, goal and habits, virtues and relationships).

Most consistently, from the positive psychology perspective, wellbeing is not simply the absence of negative function, but rather is something more. That is, a lack of negative affect, depression, loneliness, insecurity, and illness is not the same as the presence of positive affect, happiness, social connection, trust, and wellness. Further, while different theories include different domains, theorists have increasingly recognized that multidimensional models are needed to adequately capture the complexity of optimal psychological functioning (e.g., Baltes \& Baltes, 1990; Forgeard et al., 2011; Huppert \& So, 2013; Friedman \& Kern, 2014; Ryff \& Keyes, 1995).

We define "flourishing" as a dynamic optimal state of psychosocial functioning that arises from functioning well across multiple psychosocial domains. We suggest that there is no single best model of wellbeing, but different conceptualizations can be helpful for taking the abstract construct of wellbeing and providing concrete domains that can be measured, developed, and sustained. Specifically, we focus here on the five domains defined by Seligman's (2011) PERMA theory: positive emotion $(\mathrm{P})$, engagement $(\mathrm{E})$, relationships $(\mathrm{R})$, meaning $(\mathrm{M})$, and accomplishment (A).

\subsection{Positive emotion}

Emotions can be classified as a circumplex consisting of valence (negative to positive) and activation (low to high) dimensions (Cacioppo, Berntson, Norris, \& Gollan, 2011; Huelsmann, Nemanick, \& Munz, 1998). People can experience both negative and positive emotions simultaneously (Watson \& Tellegen, 1985). Numerous reviews support the value of positive 
emotion across a range of life outcomes (Howell, Kern, \& Lyubomirsky, 2007; Huppert, 2009; Lyubomirsky et al., 2005). Valid and reliable measures, at the individual and national level, have existed for several decades (OECD, 2013).

\subsection{Engagement}

Research on engagement has occurred across several relatively disparate domains. In positive psychology, measures have focused on flow, or an extreme level of psychological engagement that involves intense concentration, absorption, and focus (Csikszentmihalyi, 1990). In the organizational domain, work engagement has been defined in terms of vigor, dedication, and absorption (Schaufeli, Bakker, \& Salanova, 2006). Student engagement includes psychological, behavioral, cognitive, and academic domains (Appleton, Christenson, \& Furlong 2008). Engagement is also an important component of successful aging (Rowe \& Kahn, 1987), but little work has attempted to measure engagement in older age beyond activity involvement. Across these fields, engagement seemingly involves emotional, cognitive, and behavioral dimensions, but it is not clear how to succinctly capture these dimensions in a brief measure.

\subsection{Relationships}

Social relationships are fundamental to life (Berscheid \& Reis, 1998). A review found over 18,000 articles published on social relationships and health in the past decade alone (Tay, Tan, Diener, \& Gonzalez, 2012). Social support has been linked to less depression and psychopathology, better physical health, lower mortality risk, healthier behaviors, and other positive outcomes (Tay et al., 2012; Taylor, 2011). Sub-domains include social ties (number of persons in social sphere), social networks (number of ties and quality of those ties), received support (objective perspective of resources), perceived support (subjective perspective of resources), satisfaction with support, and giving support to others (Taga, 2006). The relationship dimension has a well-established place in most of the major existing wellbeing surveys used internationally.

\subsection{Meaning}

A sense of meaning has been defined in terms of having direction in life, connecting to something larger than oneself, feeling that one's life is valuable and worthwhile, and that there is a purpose to what one does (Steger, 2012). Meaning provides a sense that one's life matters. It has been linked to better physical health, reduced mortality risk, and higher life satisfaction (Boyle, Barnes, Buchman, \& Bennett, 2009; Ryff, Singer, \& Love, 2004; Steger, 2012). Several of the national surveys, including the experimental opinions survey developed by the UK Office for National Statistics (2011), have included single items assessing a sense of value or purpose.

\subsection{Accomplishment}

Superior performance is often recognized and acknowledged in Western societies. For example, each year Forbes magazine selects the 500 best companies in the US, and every two years Olympic events bring together the best athletes from around the world. However, objective success is also impacted by circumstances, opportunities, and personal ambitions. A mother who raises a connected, compassionate family might be considered a success, despite never receiving awards 
for her efforts. Subjectively, accomplishment involves a sense of working toward and reaching goals, mastery, and efficacy to complete tasks. Indeed, Self-Determination Theory suggests that competence is a core basic human need (Ryan \& Deci, 2000). Several of the existing wellbeing measures include items related to competence, mastery, or efficacy, whereas national surveys tend to focus on objective indicators of achievement.

\section{Wellbeing measurement}

Although some critics have raised theoretical and practical concerns as to whether maximizing happiness is the best object to pursue (e.g., Ford \& Mauss, 2014; Lazarus, 2003; Miller, 2008), for those who do want to pursue happiness and wellbeing, adequate measures are needed. Welldeveloped measurement tools help us refine our theories and understanding of wellbeing. They can complement more objective measures by providing subjective perspectives, help to identify problematic policies that unintentionally cause harm, and inform cost and benefit analyses. Further, adequate measures are needed to evaluate the effectiveness of a growing number of interventions to improve wellbeing.

Of the various wellbeing theories, some have corresponding validated measures, whereas others do not (Huppert, 2014). As a whole, there are now valid measures of affect and life evaluations, but there is less evidence on the reliability and validity of eudaimonic and multidimensional measures (OECD, 2013). Keye's Mental Health Continuum Short Form, Diener's Flourishing Scale, and Huppert and So's (2013) indicators of flourishing have been tested across multiple samples (Hone et al., 2014). Considerable research has occurred with satisfaction measures (Diener, Inglehart, \& Tay, 2012). Ryff's (2014) Psychological Well-Being Scales have been tested and used across diverse samples and applications, although questions have been raised about the measure's psychometric properties (e.g., Abbott et al., 2006; 2009).

As a relatively new theory, to date there are no brief validated instruments that specifically measure the five PERMA domains. Some measures include one or two components, with the greatest emphasis on emotion and relationships. Others, such as the Flourishing Scale (Diener et al., 2010), the flourishing items (Huppert \& So, 2013), and the Brief Inventory of Thriving (Su, Tay, \& Diener, 2014) include all five constructs, but with only one or two items per domain. Huppert and So (2013) include emotional stability, optimism, resilience, self-esteem, and vitality in the flourishing items in addition to the five PERMA domains, with single items representing each domain. The 54-item Comprehensive Inventory of Thriving (Su et al., 2014) includes the PERMA components as well as a series of other domains (e.g., learning, self-worth, lack of autonomy, optimism).

We present the development and validation of the PERMA-Profiler, which involved three parts. First, we created a bank of items theoretically relevant to the five PERMA domains. Using a sample of over 3,500 participants, we reduced the items to 15 core items. Second, we confirmed the factor structure across two samples, and examined correlations with other constructs. We chose to add eight filler items, creating a final 23-item measure. Third, we tested the final measure in eight additional samples, providing psychometric and norm information. The new measure adds a tool specifically designed to assess PERMA for the toolbox of wellbeing measures. 


\section{Part 1: Measure development}

Our goal in developing the measure was to create a brief valid measure of PERMA. In creating such a measure, there is a tension between robustly capturing each domain and keeping the number of items as low as possible. Shorter measures can more easily be incorporated into other surveys or be answered repeatedly over time, but they also generally have poorer psychometric properties and lower reliability than the reliability of longer form versions (Widaman, Little, Preacher, \& Sawalini, 2011). Validity of the questionnaire matters more than reliability (John \& Soto, 2007), but reliability provides an upper bound on validity. In estimating a structural model, at least three items are needed to identify a factor and calculate reliability. To make the scale as short as possible while maintaining evidence of validity and acceptable reliability, we purposely compromised extremely high reliability to more comprehensively capture each construct (i.e., multiple sub-domains, rather than repetitive questions; Little, Linderberger, \& Nesselroade, 1999). Thus, our final measure aimed to include three items per domain that were adequately reliable, content valid, and demonstrated preliminary support for construct validity.

\subsection{The PERMA item bank}

We began by generating a large bank of items. Using Seligman's (2011) definitions of each domain, we defined specific sub-domains for each PERMA component. ${ }^{1}$ We then reviewed measures of these constructs, searching existing sources for relevant items, and generated additional questions that theoretically tapped each domain or sub-domain. Items were combined into an initial item bank with over 700 items (see Butler, 2011 for additional details).

Repeated items were removed, and then three experts in positive psychology rated each of the compiled items, based on face valid relevance to the domains and sub-domains. If raters disagreed about an item, it was excluded from further consideration. After discussion, some revisions were made to wording, and the structure of some of the remaining items was adjusted to create consistency across items. The final item bank included 109 questions theoretically relevant to one of the PERMA components (33 emotion, 23 engagement, 21 relationships, 15 meaning, 17 accomplishment). Items and sub-domain labels are noted in Appendix 1; this constitutes the PERMA item bank and formed the foundation for the rest of our development process.

Questions were placed on a graduated 0 to 10 scale, with 0 indicating extremely low levels and 10 indicating extremely high levels, and labels appearing only on the endpoints as anchors, as suggested by OECD (2013) guidelines. This 11-point Likert scaling allows a person to indicate, for example, that they are $7 / 10(70 \%)$ on a question about excitement and interest for life. Pilot testing indicated that people understood the response scale.

\footnotetext{
${ }^{1}$ Sub-domains: Positive emotion: valence and arousal for positive emotion; Engagement: absorption, interest, and involvement; Relationships: connection with others, satisfaction, and giving/receiving support; Meaning: sense of direction, transcendence (connecting to something bigger than oneself), and sense of value/worth; Accomplishment: self-efficacy, sense of accomplishment, and achieving personal goals.
} 


\subsection{Additional measures}

Along with the main PERMA items, the initial questionnaire included several additional scales. These included the eight-item version of the Center of Epidemiological Studies-Depression Scale (CESD, Eaton, Muntaner, Smith, Tien, \& Ybarra, 2004), the Satisfaction with Life Scale (SWLS, Diener, Emmons, Larsen, \& Griffin, 1985), the Flourishing Scale (Diener et al., 2010), the Short Warwick-Edinburgh Mental Wellbeing Scale (WEMWBS, Stewart-Brown et al., 2009), and the PAC-10 (Personal Action Constructs) rating scales (Little, Salmela-Aro, \& Phillips, 2007). Four health-related questions (e.g., "In general, how is your health?") and several general demographic questions (gender, age, country, education, employment, marital status) were also included. Three free-response questions, asking how the person would describe his or her personality, and additional comments, allowed participants to express themselves and aided evaluations of the quality of participant responses. The resulting questionnaire included 199 items, which took an average of 27 minutes to complete.

\subsection{Participants}

A set of participants (Sample 1, Development Sample) was recruited online through the Authentic Happiness website (www.authentichappiness.com). A link to the survey was posted on the site as a research study. Participants voluntarily completed the full 199-item questionnaire. Data were collected from 8 January 2012 through 16 August 2012. Sufficient responses (i.e., participants who completed the PERMA items) were received from 3,751 participants. ${ }^{2}$ Demographic information is summarized in Table 1 below.

\footnotetext{
2 The included responses are a self-selected sample of individuals who chose to complete the survey to help out with research, and completed the survey through the PERMA questions. 6,789 entries were begun. Many of the missing responses were due to people who started the survey, had computer troubles, and restarted the survey; we only included their full response. The survey was lengthy, so other participants dropped out before completing all of the PERMA items and thus were excluded. Demographic information was at the end, such that we could not examine characteristics of those who dropped out.
} 


\section{Table 1a. Participant demographics by sample}

\begin{tabular}{|c|c|c|c|c|c|c|c|c|c|c|c|c|c|c|c|c|c|c|c|c|c|c|}
\hline & \multicolumn{2}{|c|}{ Sample 1} & \multicolumn{2}{|c|}{ Sample 2} & \multicolumn{2}{|c|}{ Sample 3} & \multicolumn{2}{|c|}{ Sample 4} & \multicolumn{2}{|c|}{ Sample 5} & \multicolumn{2}{|c|}{ Sample 6} & \multicolumn{2}{|c|}{ Sample 7} & \multicolumn{2}{|c|}{ Sample 8} & \multicolumn{2}{|c|}{ Sample 9} & \multicolumn{2}{|c|}{ Sample 10} & \multicolumn{2}{|c|}{ Sample 11} \\
\hline & $N$ & $\%$ & $N$ & $\%$ & $N$ & $\%$ & $N$ & $\%$ & $N$ & $\%$ & $N$ & $\%$ & $N$ & $\%$ & $N$ & $\%$ & $N$ & $\%$ & $N$ & $\%$ & $N$ & $\%$ \\
\hline Total N & 3751 & & 3029 & & 408 & & 4717 & & 23692 & & 285 & & 294 & & 166 & 184 & 1846 & 782 & & & & \\
\hline \multicolumn{23}{|l|}{ Gender } \\
\hline Male & 1050 & 27.99 & 804 & 26.54 & 234 & 57.35 & 1434 & 30.40 & 15390 & 64.96 & 85 & 29.82 & 150 & 51.02 & 61 & 36.75 & 27 & 14.67 & 317 & 17.17 & 289 & 36.96 \\
\hline Female & 2459 & 65.56 & 2014 & 66.49 & 167 & 40.93 & 3029 & 64.21 & 8184 & 34.54 & 195 & 68.42 & 144 & 48.98 & 99 & 59.64 & 150 & 81.52 & 1359 & 73.62 & 493 & 63.04 \\
\hline Other & 242 & 6.45 & 211 & 6.97 & 7 & 1.70 & 254 & 5.38 & 118 & 0.50 & 5 & 1.80 & 0 & 0.00 & 6 & 3.61 & 7 & 3.80 & 170 & 9.21 & 0 & 0.00 \\
\hline \multicolumn{23}{|l|}{ Age group } \\
\hline Under 18 & 0 & 0.00 & 0 & 0.00 & 0 & 0.00 & 0 & 0.00 & 1495 & 6.31 & 0 & 0.00 & 0 & 0.00 & 1 & 0.60 & 3 & 1.63 & 1 & 0.05 & 0 & 0.00 \\
\hline 18 to 24 & 509 & 13.57 & 562 & 18.55 & 112 & 27.45 & 736 & 15.60 & 6921 & 29.21 & 30 & 10.53 & 46 & 15.65 & 27 & 16.27 & 41 & 22.28 & 293 & 15.87 & 782 & 100 \\
\hline 25 to 34 & 731 & 19.49 & 607 & 20.04 & 184 & 45.10 & 1006 & 21.33 & 4714 & 19.90 & 107 & 37.54 & 200 & 68.03 & 51 & 30.72 & 52 & 28.26 & 400 & 21.67 & 0 & 0.00 \\
\hline 35 to 44 & 723 & 19.27 & 555 & 18.32 & 65 & 15.93 & 951 & 20.16 & 3992 & 16.85 & 37 & 12.98 & 24 & 8.16 & 35 & 21.08 & 33 & 17.93 & 352 & 19.07 & 0 & 0.00 \\
\hline 45 to 54 & 778 & 20.74 & 577 & 19.05 & 24 & 5.88 & 924 & 19.59 & 3320 & 14.01 & 41 & 14.39 & 22 & 7.48 & 30 & 18.07 & 26 & 14.13 & 361 & 19.56 & 0 & 0.00 \\
\hline 55 to 64 & 547 & 14.58 & 401 & 13.24 & 13 & 3.19 & 612 & 12.97 & 1802 & 7.61 & 34 & 11.93 & 0 & 0.00 & 12 & 7.23 & 15 & 8.15 & 224 & 12.13 & 0 & 0.00 \\
\hline $65+$ & 220 & 5.87 & 124 & 4.09 & 3 & 0.74 & 216 & 4.58 & 559 & 2.36 & 36 & 12.63 & 0 & 0.00 & 4 & 2.41 & 5 & 2.72 & 50 & 2.71 & 0 & 0.00 \\
\hline Unknown & 243 & 6.48 & 203 & 6.70 & 7 & 1.72 & 272 & 5.77 & 889 & 3.75 & 0 & 0.00 & 2 & 0.68 & 6 & 3.61 & 9 & 4.89 & 165 & 8.94 & 0 & 0.00 \\
\hline \multicolumn{23}{|l|}{ World region } \\
\hline United States & 1617 & 43.11 & 1384 & 45.69 & 62 & 15.20 & 2393 & 50.73 & 12001 & 50.70 & 285 & 100 & 290 & 79.00 & 10 & 6.02 & 184 & 100 & -- & -- & 182 & 100 \\
\hline $\begin{array}{l}\text { United } \\
\text { Kingdom }\end{array}$ & 294 & 7.84 & 225 & 7.43 & 5 & 1.23 & 308 & 6.53 & 1465 & 6.20 & 0 & 0.00 & 6 & 1.60 & 14 & 8.43 & 0 & 0.00 & -- & -- & 0 & 0.00 \\
\hline Canada & 192 & 5.12 & 148 & 4.89 & 7 & 1.72 & 246 & 5.22 & 1531 & 6.50 & 0 & 0.00 & 3 & 0.80 & 5 & 3.01 & 0 & 0.00 & -- & -- & 0 & 0.00 \\
\hline $\begin{array}{l}\text { Central/ S. } \\
\text { America }\end{array}$ & 113 & 3.01 & 78 & 2.58 & 6 & 1.47 & 160 & 3.39 & 641 & 2.70 & 0 & 0.00 & 0 & 0.00 & 4 & 2.41 & 0 & 0.00 & -- & -- & 0 & 0.00 \\
\hline West Europe & 132 & 3.52 & 122 & 4.03 & 6 & 1.47 & 222 & 4.71 & 913 & 3.90 & 0 & 0.00 & 21 & 5.70 & 6 & 3.61 & 0 & 0.00 & -- & -- & 0 & 0.00 \\
\hline N. Europe & 73 & 1.95 & 48 & 1.58 & 1 & 0.25 & 117 & 2.48 & 358 & 1.50 & 0 & 0.00 & 0 & 0.00 & 1 & 0.60 & 0 & 0.00 & -- & -- & 0 & 0.00 \\
\hline S/E. Europe & 77 & 2.05 & 61 & 2.01 & 11 & 2.70 & 130 & 2.76 & 368 & 1.60 & 0 & 0.00 & 0 & 0.00 & 2 & 1.20 & 0 & 0.00 & -- & -- & 0 & 0.00 \\
\hline Middle East & 15 & 0.40 & 6 & 0.20 & 9 & 2.21 & 26 & 0.55 & 178 & 0.80 & 0 & 0.00 & 0 & 0.00 & 1 & 0.60 & 0 & 0.00 & -- & -- & 0 & 0.00 \\
\hline Africa & 25 & 0.67 & 15 & 0.50 & 0 & 0.00 & 60 & 1.27 & 269 & 1.10 & 0 & 0.00 & 0 & 0.00 & 0 & 0.00 & 0 & 0.00 & -- & -- & 0 & 0.00 \\
\hline India/SE Asia & 69 & 1.84 & 54 & 1.78 & 282 & 69.12 & 91 & 1.93 & 914 & 3.90 & 0 & 0.00 & 0 & 0.00 & 4 & 2.41 & 0 & 0.00 & -- & -- & 0 & 0.00 \\
\hline Asia & 92 & 2.45 & 70 & 2.31 & 2 & 0.49 & 126 & 2.67 & 380 & 1.60 & 0 & 0.00 & 0 & 0.00 & 2 & 1.20 & 0 & 0.00 & -- & -- & 0 & 0.00 \\
\hline $\begin{array}{l}\text { Australia/New } \\
\text { Zealand }\end{array}$ & 620 & 16.53 & 311 & 10.27 & 4 & 0.98 & 559 & 11.85 & 2686 & 11.40 & 0 & 0.00 & 5 & 1.30 & 20 & 12.00 & 0 & 0.00 & -- & -- & 0 & 0.00 \\
\hline Other & 432 & 11.52 & 507 & 16.74 & 13 & 3.19 & 279 & 5.90 & 1988 & 8.40 & 0 & 0.00 & 42 & 11.40 & 97 & 58.43 & 0 & 0.00 & -- & -- & 0 & 0.00 \\
\hline
\end{tabular}


Table 1b. Participant demographics by sample

\begin{tabular}{|c|c|c|c|c|c|c|c|c|c|c|c|c|c|c|c|c|c|c|c|c|c|c|}
\hline & \multicolumn{2}{|c|}{ Sample 1} & \multicolumn{2}{|c|}{ Sample 2} & \multicolumn{2}{|c|}{ Sample 3} & \multicolumn{2}{|c|}{ Sample 4} & \multicolumn{2}{|c|}{ Sample 5} & \multicolumn{2}{|c|}{ Sample 6} & \multicolumn{2}{|c|}{ Sample 7} & \multicolumn{2}{|c|}{ Sample 8} & \multicolumn{2}{|c|}{ Sample 9} & \multicolumn{2}{|c|}{ Sample 10} & \multicolumn{2}{|c|}{ Sample 11} \\
\hline & $N$ & $\%$ & $N$ & $\%$ & $N$ & $\%$ & $N$ & $\%$ & $N$ & $\%$ & $N$ & $\%$ & $N$ & $\%$ & $N$ & $\%$ & $N$ & $\%$ & $N$ & $\%$ & $N$ & $\%$ \\
\hline \multicolumn{23}{|l|}{ Education } \\
\hline $\begin{array}{l}\text { No high } \\
\text { school }\end{array}$ & 71 & 1.90 & 62 & 2.00 & 12 & 2.94 & 99 & 2.10 & 1628 & 6.87 & -- & -- & 0 & 0.00 & 1 & 0.60 & 2 & 1.09 & 14 & 0.80 & -- & -- \\
\hline High school & & & & & & & & & & & & & & & & & & & & & & \\
\hline $\begin{array}{l}\text { or } \\
\text { equivalent }\end{array}$ & 254 & 6.77 & 194 & 6.40 & 31 & 7.60 & 297 & 6.30 & 1597 & 6.74 & -- & -- & 3 & 1.02 & 7 & 4.22 & 5 & 2.72 & 73 & 3.95 & -- & -- \\
\hline Some college & 563 & 15.01 & 537 & 17.73 & 35 & 8.58 & 715 & 15.16 & 8827 & 37.26 & -- & -- & 16 & 5.44 & 13 & 7.83 & 41 & 22.28 & 252 & 13.65 & -- & -- \\
\hline Associates & 246 & 6.56 & 196 & 6.47 & 12 & 2.94 & 282 & 5.98 & 2246 & 9.48 & -- & -- & 4 & 1.36 & 4 & 2.41 & 17 & 9.24 & 116 & 6.28 & -- & -- \\
\hline Bachelors & 819 & 21.83 & 616 & 20.34 & 172 & 42.16 & 1024 & 21.71 & 6305 & 26.61 & -- & -- & 170 & 57.82 & 56 & 33.73 & 42 & 22.83 & 414 & 22.43 & -- & -- \\
\hline $\begin{array}{l}\text { Some } \\
\text { graduate }\end{array}$ & 359 & 9.57 & 244 & 8.06 & 15 & 3.68 & 417 & 8.84 & $\begin{array}{c}2994 \\
\text { a }\end{array}$ & 12.64 & -- & -- & 16 & 5.44 & 20 & 12.05 & 25 & 13.59 & 133 & 7.20 & -- & -- \\
\hline Masters & 803 & 21.41 & 661 & 21.82 & 99 & 24.26 & 1127 & 23.89 & -- & -- & -- & -- & 74 & 25.17 & 46 & 27.71 & 35 & 19.02 & 483 & 26.16 & -- & -- \\
\hline $\begin{array}{l}\text { Doctorate/ } \\
\text { Professional }\end{array}$ & 399 & 10.60 & 317 & 10.40 & 24 & 5.90 & 511 & 10.80 & -- & -- & -- & -- & 9 & 3.06 & 17 & 10.20 & 10 & 5.50 & 188 & 10.90 & -- & -- \\
\hline Other & 237 & 6.32 & 202 & 6.67 & 8 & 1.96 & 245 & 5.20 & 95 & 0.40 & -- & -- & 2 & 0.70 & 2 & 1.20 & 7 & 3.80 & 173 & 9.40 & -- & -- \\
\hline \multicolumn{23}{|c|}{ Employment status } \\
\hline $\begin{array}{l}\text { Full-time } \\
\text { employment }\end{array}$ & 1845 & 49.19 & 1398 & 46.15 & 153 & 37.50 & 2191 & 46.45 & -- & -- & -- & -- & 294 & 100 & 86 & 51.81 & 61 & 33.15 & 701 & 37.97 & -- & -- \\
\hline $\begin{array}{l}\text { Part-time } \\
\text { employment }\end{array}$ & 456 & 12.16 & 386 & 12.74 & 86 & 21.08 & 533 & 11.30 & -- & -- & -- & -- & 0 & 0.00 & 14 & 8.43 & 22 & 11.96 & 223 & 12.08 & -- & -- \\
\hline Unemployed & 176 & 4.69 & 127 & 4.19 & 34 & 8.33 & 198 & 4.20 & -- & -- & -- & -- & 0 & 0.00 & 5 & 3.01 & 7 & 3.80 & 124 & 6.72 & -- & -- \\
\hline Homemaker & 113 & 3.01 & 80 & 2.64 & 36 & 8.82 & 117 & 2.48 & -- & -- & -- & -- & 0 & 0.00 & 3 & 1.81 & 5 & 2.72 & 81 & 4.39 & -- & -- \\
\hline Student & 553 & 14.74 & 543 & 17.93 & 71 & 17.40 & 700 & 14.84 & -- & -- & -- & -- & 0 & 0.00 & 17 & 10.24 & 51 & 27.72 & 298 & 16.14 & -- & -- \\
\hline Retired & 182 & 4.85 & 136 & 4.49 & 8 & 1.96 & 187 & 3.96 & -- & -- & -- & -- & 0 & 0.00 & 5 & 3.01 & 10 & 5.43 & 64 & 3.47 & -- & -- \\
\hline Other & 191 & 5.09 & 163 & 5.38 & 14 & 3.43 & 546 & 11.60 & -- & -- & -- & -- & 0 & 0.00 & 34 & 20.60 & 21 & 11.40 & 195 & 10.60 & -- & -- \\
\hline Unknown & 235 & 6.26 & 196 & 6.47 & 6 & 1.47 & 245 & 5.19 & -- & -- & -- & -- & 0 & 0.00 & 2 & 1.20 & 7 & 3.80 & 160 & 8.67 & -- & -- \\
\hline
\end{tabular}

Note. Other includes unknown/ not reported. For location, $\mathrm{N}=$ north, $\mathrm{S}=$ south, $\mathrm{E}=$ east, $\mathrm{W}=$ west. For main norming sample, graduate work refers to any post graduate training and degree, including certificates, masters, doctorate, and professional degrees.

1 = Development sample, 2 = Validation sample, $3=$ Mturk sample, $4=$ Brief measure test set, 5 = Main norming sample, $6=$ Compassion study, $7=$ Online company employees, 8 = Values study, 9 = Harvard University students, 10 = positive intervention study, $11=$ William \& Mary University students. 


\subsection{Analyses and results}

In generating the initial items, we included both general and specific time scales (i.e., "in general" versus "in the past week"). For analysis, we chose to focus on more stable aspects of wellbeing rather than transient mood. There is no agreement over the best response period for wellbeing questions (OECD, 2013). Specific periods (e.g., yesterday, currently) capture momentary states and are more susceptible to change, whereas a general response captures more stable reflections of one's wellbeing. Arguably, emotion is more transient in nature compared to the other PERMA domains. Still, Seligman (2011) discusses the five domains, including emotion, as outcomes that people seek, suggesting a more stable reflection on one's emotional balance. We follow this framing here with the general response format, such that items with the stem "in the past week" were excluded from the analysis, whereas items with the stem "in general" were included.

We also chose to only include positively worded items. It is often argued that inverse items are needed to deal with response set biases, but this assumes that positive and negative items measure the same construct, which both theoretically and empirically is not necessarily true. Numerous theorists in positive psychology have noted that it is misleading to interpret happiness as merely the opposite of unhappiness; one is not simply the lack of the other (e.g., Pawelski, 2013). Further, reversed-scored items often cluster on a separate factor, thus creating method-induced biases (e.g., Carlson et al., 2011; Dunbar, Ford, Hunt, \& Der, 2000; Marsh, 1986). Marsh (1996) noted that additional analyses are needed to disentangle response versus method bias. Alternatively, additional negatively worded items can be included but not scored as part of the positive constructs, thus disrupting response biases but not introducing the method bias. We chose to follow this latter approach. As much of the psychological literature has focused on the negative end of psychological function, and the PERMA measure is intended to complement existing measures, we focus primarily on positively worded items, but add several negative emotion questions to the final measure.

These exclusions resulted in 70 positively worded items that specifically measured PERMA. To further reduce the number of questions, participants were randomly split into two halves (Set 1: $n=1,877$ (65.1\% female); Set 2: $n=1,874(66.0 \%$ female)). In each set, we conducted an exploratory principal components analysis (Jolliffe, 2002), specifying a five-factor structure and direct oblimin rotation $(\Delta=0)$. We retained items that overlapped across the two sets. We examined response frequencies and item distributions. To ensure that items aligned with the PERMA theory, we returned to our original definitions. For the final set of items, we selected those that consistently appeared in the factor in both sub-samples in the principal components analyses, represented multiple sub-domains (e.g., absorption, effort, and interest for engagement), and had responses to the item that were normally distributed across the sample. Through these analyses, we narrowed the items down to the targeted three items for each domain (15 items total).

We then calculated four estimates of internal consistency (Cronbach's $\alpha$, Guttman's $\lambda_{6}$, minimum and maximum split half reliability ( $\beta$ and $\left.\lambda_{4}\right)$ ), using the psych package (Revelle, 2015) in $R$ (version 3.0.3), based on 10,000 random draws across the data. As summarized in Table 2 below, the factors demonstrated acceptable reliability in the two subsets.

In sum, through a combination of theory and empirical analyses, we first created a large pool of items containing questions theoretically relevant to each of the five PERMA domains, and then reduced these items to a brief measure that loaded on the expected factor and demonstrated adequate reliability. This set the stage for Part 2, in which we confirmed the factor structure in two additional samples and tested correlations with other constructs. 
Table 2a. Internal and test-retest reliability for the PERMA factors by sample

\begin{tabular}{lcccccccc}
\hline & P & E & R & M & A & Overall & NE & H \\
\hline \multicolumn{7}{c}{ Internal Reliability } \\
Sample 1a (Development sample, & subset $1, n=1,877)$ & & & & \\
Cronbach's $\alpha$ & .82 & .80 & .82 & .92 & .84 & .94 & .74 & .91 \\
Guttman's $\lambda_{6}$ & .75 & .73 & .77 & .89 & .81 & .95 & .66 & .89 \\
Minimum split half $(\beta)$ & .74 & .64 & .66 & .82 & .79 & .89 & .66 & .74 \\
Maximum split half $\left(\lambda_{4}\right)$ & .74 & .73 & .75 & .84 & .80 & .97 & .69 & .85
\end{tabular}

Sample $\mathbf{1 b}$ (Development sample, subset $2, n=1,874$ )

$\begin{array}{lllllllll}\text { Cronbach's } \alpha & .81 & .79 & .83 & .92 & .86 & .95 & .73 & .90 \\ \text { Guttman's } \lambda_{6} & .74 & .73 & .78 & .89 & .82 & .95 & .64 & .88 \\ \text { Minimum split half }(\beta) & .73 & .65 & .67 & .82 & .80 & .88 & .64 & .73 \\ \text { Maximum split half }\left(\lambda_{4}\right) & .74 & .72 & .75 & .84 & .80 & .96 & .67 & .84\end{array}$

Sample 2 (Validation sample, $n=3,029$ )

$\begin{array}{lllllllll}\text { Cronbach's } \alpha & .81 & .81 & .83 & .92 & .85 & .95 & .73 & .90 \\ \text { Guttman's } \lambda_{6} & .75 & .75 & .78 & .88 & .81 & .95 & .64 & .88 \\ \text { Minimum split half }(\beta) & .74 & .65 & .68 & .81 & .79 & .88 & .63 & .73 \\ \text { Maximum split half }\left(\lambda_{4}\right) & .75 & .74 & .76 & .84 & .80 & .97 & .68 & .85\end{array}$

Sample 3 (Mturk sample, $n=408$ )

$\begin{array}{lllllllll}\text { Cronbach's } \alpha & .71 & .69 & .79 & .86 & .82 & .94 & .76 & .85 \\ \text { Guttman's } \lambda_{6} & .63 & .62 & .72 & .81 & .77 & .95 & .68 & .81 \\ \text { Minimum split half }(\beta) & .61 & .62 & .66 & .76 & .75 & .89 & .66 & .70 \\ \text { Maximum split half }\left(\lambda_{4}\right) & .71 & .72 & .70 & .81 & .75 & .96 & .66 & .79\end{array}$

Sample 4 (Brief measure test set, $N=4,717$ )

$\begin{array}{lllllllll}\text { Cronbach's } \alpha & .89 & .72 & .84 & .91 & .78 & .94 & .75 & .92 \\ \text { Guttman's } \lambda_{6} & .84 & .64 & .79 & .87 & .73 & .95 & .67 & .89 \\ \text { Minimum split half }(\beta) & .79 & .62 & .68 & .81 & .72 & .89 & .65 & .81 \\ \text { Maximum split half }\left(\lambda_{4}\right) & .81 & .68 & .79 & .82 & .76 & .97 & .70 & .83\end{array}$

Sample 5 (Main norming set, $n=23,692$

$\begin{array}{lllllllll}\text { Cronbach's } \alpha & .88 & .71 & .81 & .90 & .79 & .94 & .73 & .92 \\ \text { Guttman's } \lambda_{6} & .83 & .63 & .76 & .86 & .73 & .95 & .64 & .88 \\ \text { Minimum split half }(\beta) & .80 & .63 & .65 & .80 & .72 & .88 & .62 & .80 \\ \text { Maximum split half }\left(\lambda_{4}\right) & .80 & .69 & .77 & .80 & .76 & .96 & .62 & .82\end{array}$

Sample 6 (Compassion study, $n=285$ )

$\begin{array}{lllllllll}\text { Cronbach's } \alpha & .88 & .80 & .82 & .89 & .80 & .93 & -- & -- \\ \text { Guttman's } \lambda_{6} & .83 & .74 & .80 & .85 & .76 & .95 & -- & -- \\ \text { Minimum split half }(\beta) & .76 & .63 & .58 & .80 & .74 & .82 & -- & -- \\ \text { Maximum split half }\left(\lambda_{4}\right) & .81 & .76 & .81 & .82 & .80 & .97 & -- & --\end{array}$

Sample 7 (Online company employees, $n=294$ )

Cronbach's $\alpha$

Guttman's $\lambda_{6}$

Minimum split half $(\beta)$

$.84 \quad .69$

$.79 \quad .62$

$.68 \quad .63$

$.79 \quad .70$

Maximum split half $\left(\lambda_{4}\right)$ $\begin{array}{llll}69 & .77 & .89 & .70\end{array}$

$\begin{array}{llll}62 & .71 & .85 & .68\end{array}$

$\begin{array}{llll}.63 & .61 & .79 & .72\end{array}$
.92

.94

.82

.96 
Table $2 \mathrm{~b}$. Internal and test-retest reliability for the PERMA factors by sample

\begin{tabular}{|c|c|c|c|c|c|c|c|c|}
\hline & $\mathbf{P}$ & $\mathrm{E}$ & $\mathbf{R}$ & $\mathbf{M}$ & $\mathbf{A}$ & Overall & NE & $\mathbf{H}$ \\
\hline \multicolumn{9}{|c|}{ Sample 8 (Values study, $n=166$ ) } \\
\hline Cronbach's $\alpha$ & .85 & .67 & .84 & .90 & .77 & .93 & .71 & .92 \\
\hline Guttman's $\lambda_{6}$ & .79 & .59 & .78 & .87 & .71 & .95 & .63 & .88 \\
\hline Minimum split half $(\beta)$ & .74 & .61 & .69 & .81 & .69 & .82 & .59 & .81 \\
\hline Maximum split half $\left(\lambda_{4}\right)$ & .79 & .64 & .76 & .83 & .76 & .97 & .61 & .82 \\
\hline \multicolumn{9}{|c|}{ Sample 9 (Harvard University students, $n=184$ ) } \\
\hline Cronbach's $\alpha$ & .85 & .73 & .83 & .85 & .79 & .92 & .77 & .94 \\
\hline Guttman's $\lambda_{6}$ & .81 & .65 & .80 & .81 & .72 & .95 & .71 & .91 \\
\hline Minimum split half $(\beta)$ & .79 & .61 & .64 & .75 & .69 & .84 & .63 & .83 \\
\hline Maximum split half $\left(\lambda_{4}\right)$ & .80 & .70 & .77 & .82 & .77 & .97 & .64 & .83 \\
\hline \multicolumn{9}{|c|}{ Sample 10 (Positive intervention study, $n=1,846$ ) } \\
\hline Cronbach's $\alpha$ & .88 & .72 & .85 & .91 & .78 & .94 & .73 & .92 \\
\hline Guttman's $\lambda_{6}$ & .84 & .63 & .81 & .87 & .73 & .96 & .65 & .89 \\
\hline Minimum split half $(\beta)$ & .80 & .63 & .68 & .81 & .72 & .88 & 61 & .81 \\
\hline Maximum split half $\left(\lambda_{4}\right)$ & .80 & .66 & .78 & .83 & .77 & .97 & .64 & .83 \\
\hline \multicolumn{9}{|c|}{ Sample 11 (William $\mathcal{E}$ Mary University students, $n=782$ ) } \\
\hline Cronbach's $\alpha$ & .84 & .60 & .75 & .90 & .84 & .93 & .70 & -- \\
\hline Guttman's $\lambda_{6}$ & .78 & .53 & .70 & .85 & .79 & .95 & .61 & -- \\
\hline Minimum split half $(\beta)$ & .75 & .54 & .56 & .80 & .70 & .87 & .63 & -- \\
\hline Maximum split half $\left(\lambda_{4}\right)$ & .76 & .66 & .73 & .81 & .80 & .96 & .65 & -- \\
\hline \multicolumn{9}{|c|}{ Combined samples (Samples $4-11, n=31,966$ ) } \\
\hline Cronbach's $\alpha$ & .88 & .72 & .82 & .90 & .79 & .94 & .71 & .92 \\
\hline Guttman's $\lambda_{6}$ & .83 & .64 & .76 & .86 & .74 & .95 & .63 & .88 \\
\hline Minimum split half $(\beta)$ & .80 & .63 & .65 & .80 & .73 & .88 & .59 & .80 \\
\hline Maximum split half $\left(\lambda_{4}\right)$ & .80 & .69 & .77 & .81 & .77 & .96 & .62 & .82 \\
\hline \multicolumn{9}{|c|}{ Test-Retest Reliability (Pearson $r$ ) } \\
\hline Sample 4 Time $2(n=1,073)$ & .84 & .78 & .83 & .86 & .80 & .88 & .77 & .86 \\
\hline Sample 5 Time $2(n=1372)$ & .68 & .61 & .68 & .67 & .67 & .80 & .66 & .78 \\
\hline Sample 5 Time $3(n=574)$ & .65 & .53 & .66 & .61 & .62 & .69 & .67 & .75 \\
\hline Sample 8 Time $2(n=45)$ & .88 & .81 & .90 & .83 & .78 & .87 & .77 & .81 \\
\hline Sample 9 Time $2(n=107)$ & .72 & .71 & .75 & .73 & .67 & .75 & .66 & .80 \\
\hline Sample 9 Time $3(n=86)$ & .70 & .51 & .70 & .69 & .68 & .69 & .62 & .79 \\
\hline
\end{tabular}

Note. See method for sample details. Samples 1-3 completed the full 199-item bank; samples 4-11 completed the brief final measure (at least the 15 items and in most cases the 23-item measure, as well as other items (see Appendix 2 for details). $\mathrm{P}=$ positive emotion, $\mathrm{E}=$ engagement, $\mathrm{R}=$ relationships, $\mathrm{M}=$ meaning, $\mathrm{A}=$ accomplishment, Overall = overall wellbeing, $\mathrm{NE}=$ negative emotion, $\mathrm{H}$ = physical health. Minimum and maximum split halves are based on 10,000 random draws across the data, estimated with the psych package (Revelle, 2015) in R.

\section{Part 2: Model testing and measure refinement}

\subsection{Participants}

While we were conducting our initial analyses of the data from Sample 1, the survey remained open on the Authentic Happiness website. Responses received between 17 August 2012 and 15 
May 2013 were considered the Validation Sample (Sample 2). Of 5,724 responses that were started, 3,029 participants completed the PERMA questions. Participant demographics are summarized in Table 1 above.

Another set of participants (Sample 3, MTurk Sample) were recruited through Amazon's Mechanical Turk (MTurk), a crowd sourcing online system in which "workers" complete tasks online for minimal payment. Several studies have found that Mturk samples are often more representative than many typical psychology studies (Berinsky, Huber, \& Lenz, 2011; Buhrmester, Kwang, \& Gosling, 2011), although the quality and participant characteristics must be carefully examined (Shapiro, Chandler, \& Mueller, 2013). We required that participants be proficient in English and have an approval rating of 95\% or above ${ }^{3}$. Participants were paid $\$ 0.20$ for completing the survey, which was a typical payment amount for such a survey at the time. Survey responses were excluded if they were missing responses to the PERMA questions, completed the survey in less than five minutes (average response time for this sample was 18 minutes), or had free response questions that appeared problematic (e.g., random letters). Out of 579 individuals who started the survey, 408 participants (43.1\% female) had sufficient data to be included in our analyses. Table 1 above summarizes demographic information.

\subsection{Data analyses and results}

Using data from Samples 2 and 3, we tested the 15-items in a confirmatory factor model (see Figure 1 below) using the lavaan package (version .5.16, Rosseel, 2012) in R (version 3.0.3). Model fit was evaluated using the root mean square error of approximation (RMSEA), and the Standardized Root Mean Residual (SRMR), which are population-based measures not affected by sample size. A RMSEA of .06 or lower combined with an SRMR of .09 or lower are considered acceptable (Hu \& Bentler, 1999). We also examined the Tucker Lewis Index (TLI) and Comparative Fit Index (CFI) as alternative incremental fit metrics; values closer to 1 are considered good fit.

Factor reliabilities are summarized in Table 2 above, and factor loadings and fit statistics are summarized in Table 3 below. In both samples, the model adequately fit the data (Sample 2: $n=$ $3,029, \mathrm{RMSEA}=.055[90 \%$ confidence interval $=.051, .058]$, SRMR $=.037, \mathrm{CFI}=.976, \mathrm{TLI}=.968$; Sample 3: $n=408$, RMSEA $=.077$ [.067, .087]; SRMR $=.034$, CFI $=.946$, TLI $=.929$ ), and factors were generally reliable, although engagement was the weakest factor in both samples.

To consider initial evidence for convergent and divergent validity, we then examined correlations of each factor with the additional measures included in the full 199-item questionnaire. Average correlations across Samples 1a, 1b, 2, and 3 are summarized in Table 4 below, and correlations for each sample are summarized in Appendix 2. The strength of correlations varied for the different PERMA factors, but all showed a similar pattern. The PERMA factors were strongly correlated with flourishing and life satisfaction, with the factor of meaning being the strongest correlate and engagement the weakest. The PERMA factors were moderately correlated with physical health, and inversely correlated with negative emotion and loneliness. The factors were also strongly correlated with the PAC-10, which asks how meaningful, exciting, enjoyable, and manageable personal projects and goals are, as well as how much these projects and goals benefit and are supported by others. In sum, the factors all correlated in the expected directions with all other measured variables.

\footnotetext{
${ }^{3}$ To help control quality, MTurk includes an approval system. If a worker provides poor data (e.g., cheating, clearly not attending to the task), an experimenter can report the worker, dropping that worker's approval rating.
} 
Figure 1. Five-factor model based on the 15 PERMA measure. See Table 3 below for estimated latent factor loadings and fit indices

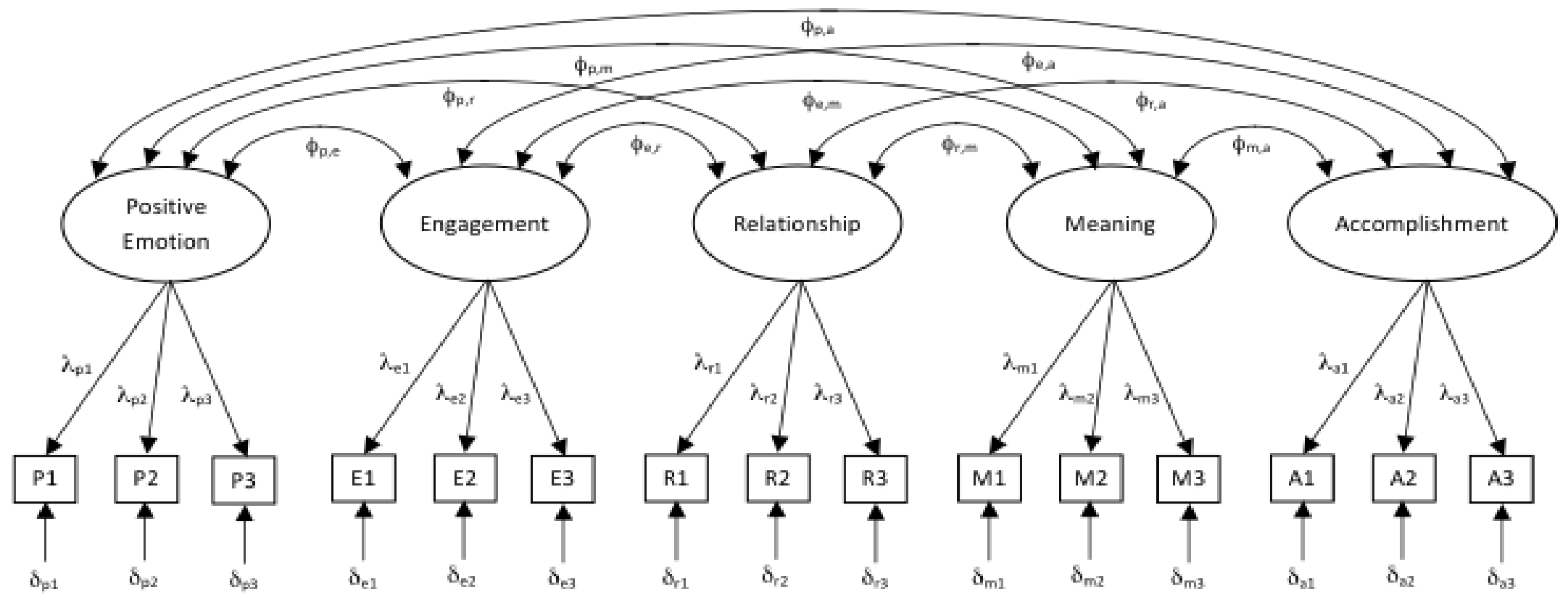


Table 3a. Latent factor loadings and fit indices in confirmatory factor analysis for the main 15 PERMA items

\begin{tabular}{|c|c|c|c|c|c|c|c|c|c|c|c|c|}
\hline Factor/Question & & 2 & 3 & 4 & 5 & 6 & 7 & 8 & 9 & 10 & 11 & Combo \\
\hline \multicolumn{13}{|l|}{ Positive Emotion } \\
\hline How often do you feel joyful? & $\lambda_{\mathrm{p} 1}$ & .78 & .72 & .84 & .87 & .89 & .70 & .81 & .87 & .85 & .80 & .86 \\
\hline How often do you feel positive? & $\lambda_{\mathrm{p} 2}$ & .85 & .76 & .88 & .87 & .80 & .86 & .85 & .88 & .86 & .85 & .87 \\
\hline To what extent do you feel contented? & $\lambda_{\mathrm{p} 3}$ & .68 & .51 & .83 & .79 & .83 & .84 & .78 & .71 & .84 & .73 & .80 \\
\hline
\end{tabular}

\section{Engagement}

How often do you become absorbed in what you are

doing?

To what extent do you feel excited and interested in

things?

How often do you lose track of time while doing

something you enjoy?

$\begin{array}{llllllllllll}\lambda_{\mathrm{e} 1} & .79 & .79 & .57 & .65 & .85 & .61 & .62 & .57 & .59 & .63 & .64 \\ \lambda_{\mathrm{e} 2} & .70 & .81 & .88 & .86 & .65 & .54 & .82 & .90 & .88 & .83 & .86 \\ \lambda_{\mathrm{e} 3} & .82 & .88 & .48 & .44 & .80 & .72 & .46 & .48 & .49 & .21 & .46\end{array}$

\section{Relationship}

To what extent do you receive help and support from others when you need it?

To what extent have you been feeling loved?

$\begin{array}{llllllllllll}\lambda_{\mathrm{r} 1} & .69 & .77 & .68 & .65 & .55 & .63 & .71 & .62 & .67 & .55 & .66 \\ \lambda_{\mathrm{r} 2} & .82 & .85 & .87 & .84 & .92 & .76 & .81 & .87 & .89 & .82 & .85 \\ \lambda_{\mathrm{r} 3} & .87 & .79 & .85 & .84 & .91 & .83 & .88 & .90 & .87 & .80 & .84\end{array}$

How satisfied are you with your personal

relationships?

\section{Meaning}

To what extent do you lead a purposeful and

meaningful life?

To what extent do you feel that what you do in your

life is valuable and worthwhile?

To what extent do you generally feel you have a sense

of direction in your life?

$\begin{array}{llllllllllll}\lambda_{\mathrm{m} 1} & .93 & .79 & .87 & .86 & .91 & .88 & .90 & .83 & .91 & .89 & .87 \\ \lambda_{\mathrm{m} 2} & .87 & .68 & .88 & .87 & .85 & .91 & .90 & .87 & .88 & .87 & .88 \\ \lambda_{\mathrm{m} 3} & .85 & .85 & .87 & .86 & .81 & .77 & .84 & .75 & .84 & .82 & .86\end{array}$

\section{Accomplishment}

How much of the time do you feel you are making

progress towards accomplishing your goals?

How often do you achieve the important goals you

have set for yourself?

$\begin{array}{llllllllllll}\lambda_{\mathrm{a} 1} & .89 & .86 & .86 & .87 & .92 & .90 & .94 & .80 & .86 & .76 & .87 \\ \lambda_{\mathrm{a} 2} & .89 & .91 & .80 & .78 & .84 & .81 & .71 & .79 & .82 & .89 & .80\end{array}$


Table 3b. Latent factor loadings and fit indices in confirmatory factor analysis for the main 15 PERMA items

\begin{tabular}{|c|c|c|c|c|c|c|c|c|c|c|c|c|}
\hline Factor/Question & & 2 & 3 & 4 & 5 & 6 & 7 & 8 & 9 & 10 & 11 & Combo \\
\hline $\begin{array}{l}\text { How often are you able to handle your } \\
\text { responsibilities? }\end{array}$ & $\lambda_{\mathrm{a} 3}$ & .66 & .91 & .56 & .57 & .50 & .36 & .46 & .65 & .54 & .78 & .58 \\
\hline \multicolumn{13}{|l|}{ Latent Factor Covariances } \\
\hline Positive Emotion $\sim$ Engagement & $\phi_{\mathrm{p}, \mathrm{e}}$ & .73 & .77 & .91 & .88 & .59 & .82 & .84 & .81 & .91 & .86 & .88 \\
\hline Positive Emotion $\sim$ Relationship & $\phi_{\mathrm{p}, \mathrm{r}}$ & .72 & .87 & .78 & .78 & .71 & .77 & .79 & .53 & .78 & .79 & .78 \\
\hline Positive Emotion $\sim$ Meaning & $\phi_{\mathrm{p}, \mathrm{m}}$ & .80 & .83 & .87 & .84 & .68 & .73 & .76 & .79 & .86 & .86 & .85 \\
\hline Positive Emotion $~$ Accomplishment & $\phi_{\mathrm{p}, \mathrm{a}}$ & .70 & .82 & .84 & .79 & .66 & .63 & .70 & .72 & .80 & .73 & .80 \\
\hline Engagement $\sim$ Relationship & $\phi_{\mathrm{e}, \mathrm{r}}$ & .58 & .84 & .68 & .64 & .30 & .67 & .55 & .36 & .63 & .72 & .65 \\
\hline Engagement $\sim$ Meaning & $\phi_{\mathrm{e}, \mathrm{m}}$ & .77 & .95 & .81 & .81 & .54 & .70 & .74 & .72 & .86 & .87 & .82 \\
\hline Engagement $\sim$ Accomplishment & $\phi_{\mathrm{e}, \mathrm{a}}$ & .78 & .92 & .79 & .79 & .59 & .83 & .72 & .62 & .78 & .77 & .80 \\
\hline Relationship Meaning & $\phi_{\mathrm{r}, \mathrm{m}}$ & .71 & .93 & .69 & .69 & .65 & .74 & .54 & .49 & .68 & .73 & .69 \\
\hline Relationship $\sim$ Accomplishment & $\phi_{\mathrm{r}, \mathrm{a}}$ & .62 & .89 & .64 & .64 & .46 & .53 & .49 & .46 & .58 & .65 & .64 \\
\hline Meaning Accomplishment & $\phi_{\mathrm{m}, \mathrm{a}}$ & .81 & .96 & .92 & .93 & .66 & .57 & .89 & .83 & .86 & .79 & .91 \\
\hline \multicolumn{13}{|l|}{ Model Fit } \\
\hline $\mathrm{N}$ & & 3029 & 408 & 4717 & 23692 & 285 & 294 & 166 & 184 & 1846 & 782 & 31966 \\
\hline RMSEA & & .055 & .077 & .064 & .066 & .081 & .098 & .098 & .107 & .082 & .081 & .064 \\
\hline RMSEA 90\% confidence interval & & $\begin{array}{l}.051 \\
.058\end{array}$ & $\begin{array}{r}.067 \\
.087\end{array}$ & $\begin{array}{l}.062 \\
.067\end{array}$ & $\begin{array}{l}.065 \\
.067\end{array}$ & $\begin{array}{r}.069 \\
.094\end{array}$ & $\begin{array}{l}.087 \\
.110\end{array}$ & $\begin{array}{r}.081 \\
.114\end{array}$ & $\begin{array}{l}.092 \\
.122\end{array}$ & $\begin{array}{l}.078 \\
.086\end{array}$ & $\begin{array}{r}.074 \\
.088\end{array}$ & $\begin{array}{r}.063 \\
.065\end{array}$ \\
\hline SRMR & & .037 & .034 & .031 & .032 & .067 & .068 & .063 & .074 & .04 & .043 & .031 \\
\hline$\chi^{2}(\mathrm{df}=80)$ & & 790 & 274 & 1639 & 8347 & 231 & 308 & 207 & 249 & 1070 & 489 & 10606 \\
\hline CFI & & .976 & .946 & .967 & .964 & .944 & .905 & .919 & .896 & .949 & .941 & .967 \\
\hline TLI & & .968 & .929 & .957 & .953 & .927 & .875 & .894 & .864 & .932 & .923 & .956 \\
\hline
\end{tabular}

Note. Confirmatory factor analysis estimated using the lavaan package (version 0.5.16) in R (version 3.0.3). See Figure 1 above for the estimated model. RMSEA = Root Mean Square Error of Approximation, SRMR = Standardized Root Mean Residual, CFI = Comparative Fit Index, TLI = Tucker Lewis Index. $2=$ Validation sample, $3=$ Mturk sample, $4=$ Brief measure test set, $5=$ Main norming sample, $6=$ Compassion study, $7=$ Online company employees, $8=$ Values study, $9=$ Harvard University students, $10=$ Positive intervention study, 11 = William \& Mary University students. Combo combines samples 4-11 (participants who completed the final brief measure). 
Table 4. Evidence for convergent and divergent validity: Average correlations with other constructs

\begin{tabular}{|c|c|c|c|c|c|c|c|c|c|c|}
\hline & $n$ & K & $\mathbf{P}$ & $\mathbf{E}$ & $\mathbf{R}$ & $\mathbf{M}$ & A & Overall & NE & $\mathbf{H}$ \\
\hline \multicolumn{11}{|c|}{ Initial 199 survey (Samples $1 a, 1 b, 2$, and 3) } \\
\hline Positive emotion & 6995 & 4 & & & & & & & & \\
\hline Engagement & 7000 & 4 & .59 & & & & & & & \\
\hline Relationship & 7016 & 4 & .61 & .52 & & & & & & \\
\hline Meaning & 7004 & 4 & .69 & .68 & .65 & & & & & \\
\hline Accomplishment & 6999 & 4 & .61 & .65 & .56 & .74 & & & & \\
\hline Overall wellbeing & 7066 & 4 & .83 & .80 & .81 & .90 & .84 & & & \\
\hline Negative emotion & 6979 & 4 & -.49 & -.34 & -.42 & -.45 & -.43 & -.52 & & \\
\hline Physical health & 6791 & 4 & .36 & .31 & .34 & .37 & .41 & .43 & -.28 & \\
\hline Loneliness & 6942 & 4 & -.40 & -.29 & -.55 & -.42 & -.36 & -.49 & .41 & -.23 \\
\hline Depression & 6733 & 4 & -.65 & -.53 & -.64 & -.66 & -.59 & -.74 & .61 & -.42 \\
\hline Flourishing & 6739 & 4 & .67 & .64 & .68 & .81 & .70 & .84 & -.48 & .40 \\
\hline Life satisfaction & 6830 & 4 & .65 & .53 & .68 & .73 & .65 & .79 & -.48 & .43 \\
\hline Рac-10 & 6640 & 4 & .64 & .62 & .64 & .75 & .66 & .80 & -.50 & .41 \\
\hline WEMWBS & 6696 & 4 & .66 & .61 & .67 & .73 & .67 & .80 & -.55 & .43 \\
\hline
\end{tabular}

Note. Values are based on the average correlation across samples that measured the construct (K), weighted by the number within that sample $(n)$. See Appendix 2 for correlations by sample and for details on how the constructs were measured. WEMWBS = Warwick-Edinburgh Mental Well-being Scale, PAC-10 $=$ Personal Action Constructs rating scales, $\mathrm{P}=$ positive emotion, $\mathrm{E}=$ engagement, $\mathrm{R}=$ relationships, $\mathrm{M}=$ meaning, $\mathrm{A}=$ accomplishment, Overall = overall wellbeing, $\mathrm{NE}=$ negative emotion, $\mathrm{H}=$ physical health.

\subsection{Measure refinement}

Overall, the 15 items demonstrated adequate psychometric properties. Over the two-year data collection period, we received various qualitative comments and emails. Some participants had voluntarily noted confusing words, errors, and order effects. Based on this feedback, we refined item wording. In addition, we chose to add eight additional items: one item assessing overall wellbeing; three negative emotion items assessing sadness, anger, and anxiety; one item assessing loneliness; and three items assessing self-perceived physical health. The final 23-item measure is provided in Table 5 below.

Domain scores are created by taking the average of the three items (for each PERMA domain, negative emotion, and health; range $=0$ to 10). Overall wellbeing is the average of the main 15 PERMA items and the overall happiness item. Loneliness is a single item.

We had two reasons for including the additional items, beyond the 15 main PERMA items. First, these items act as filler items. By including the negative emotion and loneliness items, these disrupt response tendencies, addressing the issue of not including inversely scored items as part of the PERMA constructs (Marsh, 1986). Second, these items provide additional information that may be useful for many users. The positive focus of PERMA does not negate the importance of negative emotion; by including negative emotions, the measure acknowledges the importance of considering both positive and negative elements of the mental health spectrum. 
Table 5. The final 23-item PERMA-Profiler measure

\begin{tabular}{|c|c|c|}
\hline Label & Question & Response Anchors \\
\hline A1 & $\begin{array}{l}\text { How much of the time do you feel you are making progress } \\
\text { towards accomplishing your goals? }\end{array}$ & $\begin{array}{l}0=\text { never, } 10= \\
\text { always }\end{array}$ \\
\hline E1 & How often do you become absorbed in what you are doing? & \\
\hline P1 & In general, how often do you feel joyful? & \\
\hline N1 & In general, how often do you feel anxious? & \\
\hline A2 & $\begin{array}{l}\text { How often do you achieve the important goals you have set } \\
\text { for yourself? }\end{array}$ & \\
\hline H1 & In general, how would you say your health is? & $\begin{array}{l}0=\text { terrible, } \\
10=\text { excellent }\end{array}$ \\
\hline M1 & $\begin{array}{l}\text { In general, to what extent do you lead a purposeful and } \\
\text { meaningful life? }\end{array}$ & $\begin{array}{l}0=\text { not at all, } \\
10=\text { completely }\end{array}$ \\
\hline R1 & $\begin{array}{l}\text { To what extent do you receive help and support from others } \\
\text { when you need it? }\end{array}$ & \\
\hline M2 & $\begin{array}{l}\text { In general, to what extent do you feel that what you do in } \\
\text { your life is valuable and worthwhile? }\end{array}$ & \\
\hline E2 & $\begin{array}{l}\text { In general, to what extent do you feel excited and interested } \\
\text { in things? }\end{array}$ & \\
\hline Lon & How lonely do you feel in your daily life? & \\
\hline $\mathrm{H} 2$ & How satisfied are you with your current physical health? & $\begin{array}{l}0=\text { not at all, } \\
10=\text { completely }\end{array}$ \\
\hline P2 & In general, how often do you feel positive? & $\begin{array}{l}0=\text { never } \\
10=\text { always }\end{array}$ \\
\hline $\mathbf{N} 2$ & In general, how often do you feel angry? & \\
\hline A3 & How often are you able to handle your responsibilities? & \\
\hline N3 & In general, how often do you feel sad? & \\
\hline E3 & $\begin{array}{l}\text { How often do you lose track of time while doing something } \\
\text { you enjoy? }\end{array}$ & \\
\hline H3 & $\begin{array}{l}\text { Compared to others of your same age and sex, how is your } \\
\text { health? }\end{array}$ & $\begin{array}{l}0=\text { terrible, } \\
10=\text { excellent }\end{array}$ \\
\hline R2 & To what extent do you feel loved? & $\begin{array}{l}0=\text { not at all, } \\
10=\text { completely }\end{array}$ \\
\hline M3 & $\begin{array}{l}\text { To what extent do you generally feel you have a sense of } \\
\text { direction in your life? }\end{array}$ & \\
\hline R3 & How satisfied are you with your personal relationships? & \\
\hline P3 & In general, to what extent do you feel contented? & \\
\hline Hap & $\begin{array}{l}\text { Taking all things together, how happy would you say you } \\
\text { are? }\end{array}$ & $\begin{array}{l}0=\text { not at all, } \\
10=\text { completely }\end{array}$ \\
\hline
\end{tabular}

The single item on loneliness is a strong predictor of many negative life outcomes (Caccioppo, Hawkley, \& Berntson, 2003). Although PERMA focuses on psychosocial function, physical health is a correlated outcome that arguably could be considered a core part of flourishing (Friedman \& Kern, 2014; Norrish, 2015). Indeed, physical health was moderately to strongly correlated with 
each of the PERMA factors. The overall happiness item is similar to other overall assessments included in many surveys. It not only provides a link to other surveys, but also allows participants to provide an overall assessment of their own wellbeing, after reflecting on specific facets from the other questions. Thus, for both methodological and theoretical reasons, we believe there is value in including the eight additional items.

\section{Part 3: Testing the final measure}

\subsection{Participants}

In 2013, we made the final questionnaire available to other researchers and made an online version available for potential participants to complete. We conducted a series of studies that included the measure, and several other researchers included the measure within their battery of assessments, sharing de-identified data with us to contribute to norm and validity information. Each study included at least the 15 PERMA items and some demographic information. Most also included other measures, providing additional tests of convergent and divergent validity. Demographic information for each sample is summarized in Table 1 above, and the specific measures included in each sample are provided in Appendix 2. All procedures were approved by the University of Pennsylvania Institutional Review Board.

One study was designed specifically to test the reliability of the final measure in its reduced form (Sample 4, brief measure test set). During the collection of Sample 4, we posted the survey at www.permaquestionnaire.org and advertised the survey on the AuthenticHappiness.com website. Between 19 February and 10 October 2013, 4,717 participants (64.2\% female) completed the PERMA survey and were included in our analyses. At the end of the survey, participants were asked if they would be willing to complete the survey two weeks later to help establish cross-time stability. Willing participants provided contact information. Approximately two weeks later, participants were sent an invitation to complete the measure again. Between 6 March and 10 October 2013, 1,073 individuals (71.6\% female) completed the measure again and could be successfully matched to their time 1 responses.

The Authentic Happiness website offers registered users the opportunity to complete various measures. The 23-item PERMA-Profiler was added to the website in May 2014. Between 21 May 2014 and 15 March 2016, 23,692 participants (34.5\% female) from around the world completed the survey (Sample 5, main norming set). Basic demographic information (gender, age category, country, education, occupation) was also available. In addition, some participants returned at a later date, allowing us to consider stability over time. Of these, 1,372 participants (34.3\% female) completed the measure twice, with length of time between the two assessments ranging from one day to up to two years later $(\mathrm{M}=68.9$ days, $\mathrm{SD}=89.94$, Median $=49.00)$. Of these, 535 participants ( $41.4 \%$ female) completed the measure three or more times, with the length of time between the first and third assessment ranging from 1 to 633 days $(\mathrm{M}=92.7$ days, $\mathrm{SD}=77.9$, Median $=101$ ).

In a cross-sectional study focused on activism and self-compassion (Sample 6, compassion study), participants completed an online survey that included the main 15 PERMA items and the overall happiness item from the PERMA-Profiler, as well as measures of self-compassion, hope, life satisfaction, perceived success, self-determination motivation, and compassion for others. A total of 285 participants (68.4\% female) completed the survey and were included in the current analysis.

In collaboration with a creative online organization, 294 employees (49.0\% female; Sample 7, online organization employees) completed a survey that included the 15 main PERMA items and the overall happiness item from the PERMA-Profiler, as well as measures of social capital, work 
performance, and an evaluation of the organization's practices. About $85 \%$ of employees participated, including 24 teams from five global offices.

In a study focused on personal values and wellbeing (Sample 8, values study), 166 individuals (59.6\% female) completed an online survey that included the PERMA-Profiler and questions asking the extent to which 13 different values (e.g., work, balance, material wellbeing, health, helping others) mattered to the person. Values were based on Schwartz's (2012) theory of basic values. A composite summed values score was calculated. After completing the survey, participants were invited to track their values and happiness each day for two weeks, and then were invited to complete the survey again. Follow-up responses were received from 45 participants $(75.6 \%$ female).

Sample 9 (Harvard University students) came from data collected from students from Harvard University enrolled in a positive psychology course. As a class learning activity, students completed a survey around weeks one, nine, and 12 that included the PERMA-Profiler, along with measures of hope, self-efficacy, gratitude, perceived stress, anxiety, depression, fatigue, and life satisfaction. After the second assessment, some students completed an online positive intervention. Data was collected across two semesters, with 184 students $(81.5 \%$ female) completing the baseline measure, 107 students ( $76.6 \%$ female) completing the second assessment, and 86 students (75.6\% female) completing the final assessment.

As part of an online intervention study, the same survey used with Sample 9 was completed by an additional 1,846 individuals (73.6\% female; Sample 9, positive intervention study). Data from the baseline survey was included in the current analysis.

In addition, 782 students (63\% female) from William and Mary University completed a 20item version of the PERMA-Profiler (main 15 PERMA items, overall happiness, negative emotion, loneliness). The de-identified scores were shared with the authors to contribute to norm information (Sample 11, William and Mary University students).

\subsection{Results}

Table 6 below summarizes descriptive information for the full combined sample (all participants who completed the reduced measure, Samples 4-11; see Appendix 3 for descriptive information split by gender, age group, and country region).

Table 6. Descriptive information for full combined sample (Samples 4-11)

\begin{tabular}{lccccccccc}
\hline & $\mathbf{N}$ & Mean & Median & SD & Min & 25th & 50th & 75th & Max \\
\hline Full Sample & & & & & & & & & \\
$\quad$ Positive emotion & 31965 & 6.69 & 7.00 & 1.97 & 0.00 & 5.67 & 7.00 & 8.00 & 10.00 \\
Engagement & 31962 & 7.25 & 7.67 & 1.71 & 0.00 & 6.33 & 7.67 & 8.33 & 10.00 \\
Relationships & 31940 & 6.90 & 7.33 & 2.15 & 0.00 & 5.67 & 7.33 & 8.67 & 10.00 \\
Meaning & 31931 & 7.06 & 7.67 & 2.17 & 0.00 & 6.00 & 7.67 & 8.67 & 10.00 \\
Accomplishment & 31963 & 7.21 & 7.67 & 1.78 & 0.00 & 6.33 & 7.67 & 8.33 & 10.00 \\
Overall wellbeing & 31966 & 7.02 & 7.38 & 1.66 & 0.00 & 6.13 & 7.38 & 8.25 & 10.00 \\
Negative emotion & 31386 & 4.46 & 4.33 & 2.06 & 0.00 & 3.00 & 4.33 & 6.00 & 10.00 \\
Physical health & 30601 & 6.94 & 7.33 & 2.18 & 0.00 & 5.67 & 7.33 & 8.67 & 10.00 \\
\hline
\end{tabular}

Reliability and model fit for each sample is summarized in Tables 2 and 3 above. Without intervention, the factors were generally stable over time. Correlations ranged from $r=.51$ for the engagement factor from baseline to time 3 in Sample 9 (12 week period) to $r=.90$ for the 
relationship factor between baseline and time 2 in Sample 8 (two week period). Associations were strongest when there were two weeks or less between measurement occasions, but correlations remained high even with longer periods of time. Intervention effects were not directly tested, but may contribute to the observed variance.

To examine convergent and divergent validity, effect sizes for the constructs assessed in each sample were meta-analytically combined (Table 7 below; see Appendix 2 for measure information and correlations within each sample).

Table 7. Evidence for convergent and divergent validity: Average correlations with other constructs (Samples 4-11)

\begin{tabular}{|c|c|c|c|c|c|c|c|c|c|c|}
\hline & $n$ & $K$ & $\mathbf{P}$ & $\mathbf{E}$ & $\mathbf{R}$ & $\mathbf{M}$ & $\mathbf{A}$ & Overall & NE & $\mathbf{H}$ \\
\hline Positive emotion & 31965 & 8 & & & & & & & & \\
\hline Engagement & 31962 & 8 & .64 & & & & & & & \\
\hline Relationship & 31940 & 8 & .68 & .46 & & & & & & \\
\hline Meaning & 31931 & 8 & .75 & .60 & .60 & & & & & \\
\hline Accomplishment & 31963 & 8 & .68 & .57 & .54 & .78 & & & & \\
\hline Overall wellbeing & 31966 & 8 & .90 & .76 & .80 & .89 & .84 & & & \\
\hline Negative emotion & 31386 & 6 & -.53 & -.28 & -.40 & -.42 & -.38 & -.49 & & \\
\hline Physical health & 30601 & 5 & .48 & .32 & .40 & .43 & .46 & .50 & -.31 & \\
\hline Loneliness & 31331 & 6 & -.45 & -.25 & -.50 & -.38 & -.32 & -.46 & .54 & -.23 \\
\hline Depression & 1974 & 2 & -.61 & -.38 & -.49 & -.55 & -.49 & -.61 & .59 & -.32 \\
\hline Anxiety & 1984 & 2 & -.53 & -.34 & -.35 & -.43 & -.44 & -.50 & .68 & -.29 \\
\hline Fatigue & 1919 & 2 & -.42 & -.30 & -.27 & -.32 & -.37 & -.40 & .47 & -.47 \\
\hline Perceived stress & 1880 & 2 & -.58 & -.34 & -.44 & -.46 & -.48 & -.55 & .67 & -.36 \\
\hline Gratitude & 1919 & 2 & .58 & .42 & .55 & .52 & .45 & .60 & -.44 & .29 \\
\hline Hope & 2225 & 3 & .66 & .56 & .45 & .68 & .69 & .73 & -.45 & .36 \\
\hline Life satisfaction & 2098 & 3 & .76 & .51 & .65 & .68 & .64 & .78 & -.53 & .44 \\
\hline Self-efficacy & 1905 & 2 & .59 & .51 & .40 & .60 & .65 & .65 & -.44 & .36 \\
\hline Values & 163 & 1 & .20 & .18 & .13 & .30 & .20 & .26 & -.15 & .23 \\
\hline Burnout & 195 & 1 & -.42 & -.43 & -.34 & -.46 & -.57 & -.56 & & \\
\hline Compassion & 264 & 1 & .13 & .25 & .02 & .19 & .15 & .17 & & \\
\hline Identifies as an activist & 285 & 1 & .01 & .18 & -.04 & .20 & .01 & .07 & & \\
\hline Political orientation & 245 & 1 & -.09 & -.15 & -.12 & -.16 & .07 & -.12 & & \\
\hline Self-compassion & 277 & 1 & .49 & .29 & .45 & .45 & .35 & .52 & & \\
\hline Self-determination & 250 & 1 & -.53 & -.35 & -.47 & -.54 & -.46 & -.60 & & \\
\hline Organization practices & 294 & 1 & .33 & .38 & .34 & .24 & .38 & .41 & & \\
\hline Social capital & 293 & 1 & .37 & .26 & .35 & .22 & .26 & .37 & & \\
\hline Work performance & 293 & 1 & .14 & .25 & .20 & .21 & .19 & .24 & & \\
\hline
\end{tabular}

Note. Values are based on the average correlation across samples that measured the construct (K), weighted by the number within that sample $(n)$. See Appendix 2 for correlations by sample and for details on how the constructs were measured. $\mathrm{P}=$ positive emotion, $\mathrm{E}=$ engagement, $\mathrm{R}=$ relationships, $\mathrm{M}=$ meaning, $\mathrm{A}=$ accomplishment, Overall = overall wellbeing, $\mathrm{NE}=$ negative emotion, $\mathrm{H}=$ physical health.

The PERMA domains generally followed similar patterns of results, but the correlation strengths varied by factor. Capturing the hedonic side of wellbeing, positive emotion was the strongest 
inverse correlate of negative emotion, depression, anxiety, fatigue, and perceived stress. Positive emotion was very strongly correlated with life satisfaction $(r=.76)$, and was only weakly correlated with compassion, a strong sense of values, political orientation, and self-rated workplace performance. Of the PERMA factors, engagement was the weakest correlate of most other variables. However, it was the strongest correlate of compassion, identifying as an activist, and workplace performance. Relationship was the strongest correlate (inverse) of loneliness; otherwise it was moderately correlated with most factors and was weaker than other factors. Meaning was the strongest correlate of having a strong sense of values and identifying as an activist - both of which represent what could be considered meaningful activities or orientations. Hope was equally correlated with meaning and accomplishment. Accomplishment was the strongest correlate of self-efficacy and less burnout.

\section{General discussion}

Through an extensive theoretical and empirical process, we developed a 23-item measure that assesses wellbeing across five domains (positive emotion, engagement, relationships, meaning, accomplishment). Seligman (2011) suggests that these five domains can be defined and measured as separate but correlated constructs. Maximizing brevity while still maintaining psychometric integrity, the scale includes acceptable internal reliability for each of the five domains and good overall model fit across over 30,000 participants worldwide.

A particular benefit of the measure is that it assesses wellbeing across multiple domains. We suggest that in presenting individual or group results, the multidimensional structure of the measure should be retained, rather than condensing responses to a single flourishing score (see Figure 2 below for an example).

Figure 2. Example way of presenting a respondent's scores, which explicitly identifies multiple domains of wellbeing. $P=$ positive emotion, $E=$ engagement, $R=$ positive relationships, $\mathrm{M}=$ meaning/purpose in life, $\mathrm{A}=$ accomplishment, $\mathrm{N}=$ negative emotion, $\mathrm{H}=$ physical health.

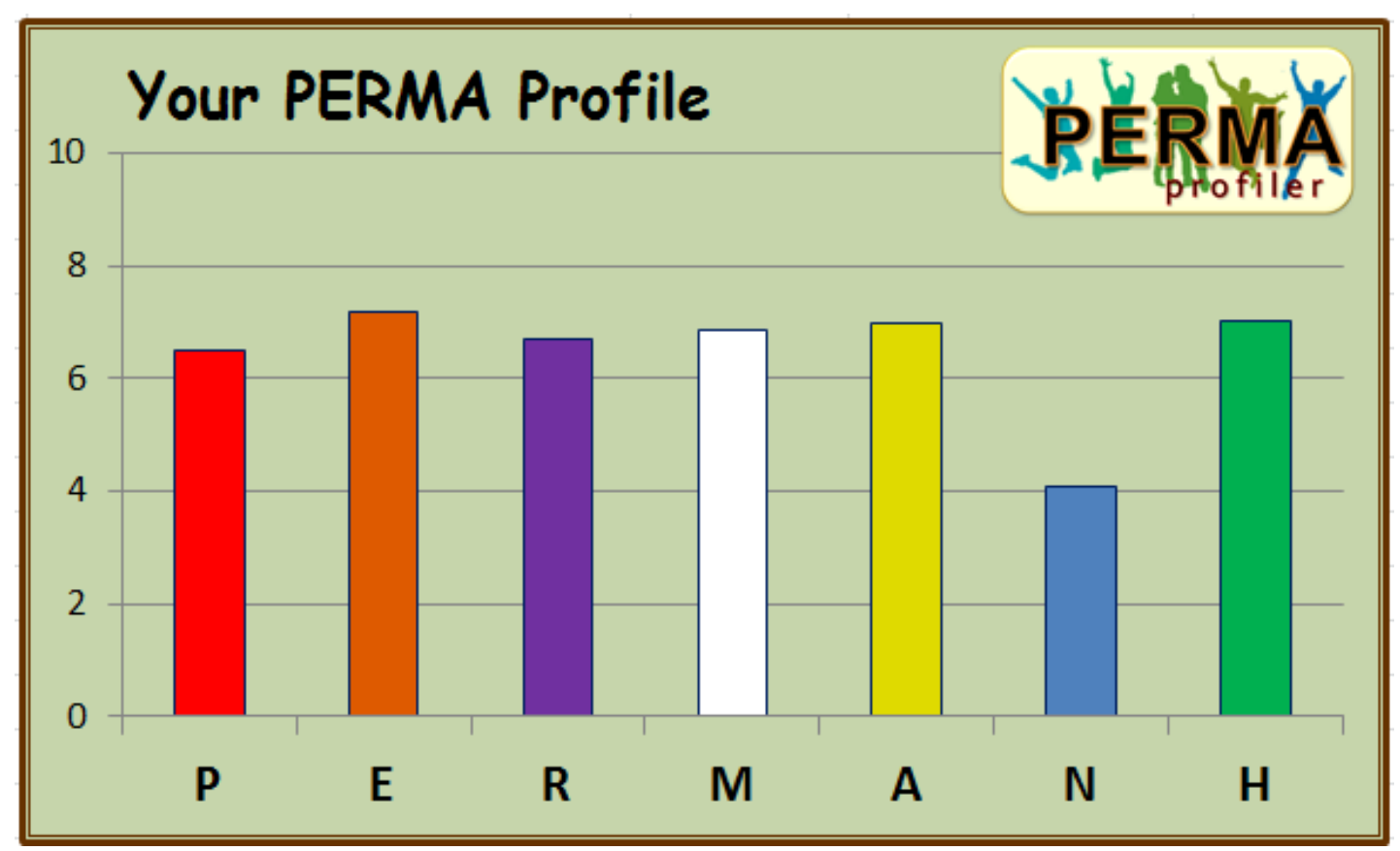


A single score assumes that the underlying measure is unidimensional, but the PERMA-Profiler was specifically designed to be multidimensional in nature. Further, while a single overall flourishing score might provide a global indication of wellbeing, it obscures potentially meaningful variation amongst the domains. For instance, if a person scores particularly low in relationships, interventions might target strategies for building social connections (see Kern, Waters, Adler, \& White, 2015; Kern, Waters, White, \& Adler 2014 for further discussion of theoretical and practical benefits of a multidimensional approach).

At this point we cannot recommend an ideal profile. Indeed, the measure is intended to be descriptive - not prescriptive - in nature. Different profiles may be more or less adaptive for different people at different times, depending on their personality, history, and social context. Future research should test downstream associations between different profiles and outcomes such as objective physical health, income, and education, as well as the moderating role of other factors such as age, culture, and life events.

The PERMA-Profiler demonstrated acceptable psychometric properties across a large, diverse, international sample. Subsequent work should examine discriminate, predictive, and additional convergent validity, and item order might be further examined. In addition, sensitivity to change with intervention should be tested. Further, stability over even longer periods of time and variations across different cultures should be examined, taking into account response styles, cultural differences, proper translation of concepts, and judgment biases (Oishi \& Schimmack, 2010). Developing a valid measure of psychological constructs is a long process if not a lifetime pursuit - requiring multiple samples and refinements in both items and theory (John \& Benet-Martinez, 2000).

Although the PERMA-Profiler is not the only measure that captures the five PERMA domains, it is the only measure to date that focuses primarily on the PERMA domains while also addressing the desirability of including several items per feature, instead of just one or two (Huppert and So, 2013). Future research might examine whether the PERMA-Profiler or an alternative measure will prove to be the most appropriate within different contexts and applications.

In conclusion, through an intensive process, we created a measure that at both content and analytical levels captures the five PERMA domains. The measure demonstrates acceptable reliability, cross-time stability, and evidence for convergent and divergent validity. The PERMAProfiler provides another tool for the wellbeing measurement toolbox. Ultimately, we hope that this tool can help people better understand themselves, note their strengths and weaknesses, and find ways to more fully flourish in life.

\section{Acknowledgments}

We thank Dr. Felicia Huppert, founder of the University of Cambridge Well-being Institute and one of the world's leading experts in wellbeing measurement, for her guidance and comments throughout the development process. We thank Rosie Hancock, MAPP, for her assistance and support in data collection and response management. We are also grateful to all the anonymous people who completed versions of the survey, provided feedback, and helped us develop, refine, and establish support for the measure.

\section{Author Note}

Support for this publication was provided by the University of Melbourne's Centre for Positive Psychology, the University of Pennsylvania's Positive Psychology Center, and the Robert Wood Johnson Foundation's "Exploring Concepts of Positive Health" grant awarded to Martin E. P. Seligman. 


\section{Authors}

Julie Butler

University of Pennsylvania

Margaret L. Kern

University of Melbourne \& University of Pennsylvania

margaret.kern@unimelb.edu.au

\section{Publishing Timeline}

Received 12 April 2016

Accepted 18 September 2016

Published 14 October 2016

\section{References}

Abbott, R. A., Ploubidis, G. B., Huppert, F. A., Kuh, D., \& Croudace, T. J. (2009). An evaluation of the precision of measurement of Ryff's psychological well-being scales in a population sample. Social Indicators Research, 97(3), 357-373. http://dx.doi.org/10.1007/s11205-009-9506-x

Abbott, R. A., Ploubidis, G. B., Huppert, F. A., Kuh, D., Wadsworth, M. E. J., \& Croudace, T. J. (2006). Psychometric evaluation and predictive validity of Ryff's psychological well-being items in a UK birth cohort sample of women. Health and Quality of Life Outcomes, 4(76).

http://dx.doi.org/10.1186/1477-7525-4-76

Appleton, J. J., Christenson, S. L., \& Furlong, M. J. (2008). Student engagement with school: Critical conceptual and methodological issues of the construct. Psychology in the Schools, 45(5), 379-386. http://dx.doi.org/10.1002/pits.20303

Baltes, P. B., \& Baltes, M. M. (1990). Psychological perspectives on successful aging: The model of selective optimization with compensation. In P. B. Baltes \& M. M. Baltes (Eds.), Successful aging: Perspectives from the behavioral sciences (pp. 1-34). New York, NY: Cambridge University Press. http://dx.doi.org/10.1017/CBO9780511665684

Berinsky, A. J., Huber, G. A., \& Lenz, G. S. (2011). Using Mechanical Turk as a subject recruitment tool for experimental research. http://web.mit.edu/berinsky/www/files/MT.pdf

Berscheid, E., \& Reis, H. T. (1998). Attraction and close relationships. In D. T. Gilbert, S. T. Fiske \& G. Lindzey (Eds.), The handbook of social psychology (4th ed., Vol. 2, pp. 193-281). New York, NY: McGraw-Hill.

Boyle, P. A., Barnes, L. L., Buchman, A. S., \& Bennett, D. A. (2009). Purpose in life is associated with mortality among community-dwelling older persons. Psychosomatic Medicine, 71(5), 574-579. http://dx.doi.org/10.1097/PSY.0b013e3181a5a7c0

Buhrmester, M., Kwang, T., \& Gosling, S. D. (2011). Amazon's Mechanical Turk: A new source of inexpensive, yet high-quality, data? Perspectives on Psychological Science, 6(1), 3-5. http://dx.doi.org/10.1177/1745691610393980

Butler, J. (2011). Measuring facets of human flourishing: Developing the well-being theory questionnaire. (Unpublished master's thesis). University of Pennsylvania, Philadelphia.

Cacioppo, J. T., Berntson, G. G., Norris, C. J., \& Gollan, J. K. (2011). The evaluative space model. In P. Van Lange, A. Kruglanski \& E. T. Higgins (Eds.), Handbook of theories of social psychology (Vol. 1). Thousand Oaks, CA: Sage.

Cacioppo, J. T., Hawkley, L. C., \& Berntson, G. G. (2003). The anatomy of loneliness. Current Directions in Psychological Science, 12(3), 71-74. http://dx.doi.org/10.1111/1467-8721.01232

Carlson, M., Wilcox, R., Chou, C.-P., Change, M., Yang, F., Blanchard, J., ..., \& Clark, F. (2011). Psychometric properties of reverse-scored items on the CES-D in a sample of ethnically diverse older adults. Psychological Assessment, 23(2), 558-562. http://dx.doi.org/10.1037/a0022484

Csikszentmihalyi, M. (1990). Flow: The psychology of optimal experience. New York, NY: Harper and Row. 
Diener, E. (1984). Subjective well-being. Psychological Bulletin, 95(3), 542-575. http://dx.doi.org/10.1037/0033-2909.95.3.542

Diener, E., \& Chan, M. (2011). Happy people live longer: Subjective wellbeing contributes to health and longevity. Applied Psychology: Health and Wellbeing, 3(1), 1-43. http://dx.doi.org/10.1111/j.17580854.2010.01045.x

Diener, E., Emmons, R. A., Larsen, R. J., \& Griffin, S. (1985). The satisfaction with life scale. Journal of Personality Assessment, 49(1), 71-75.

Diener, E., Inglehart, R., \& Tay, L. (2012). Theory and validity of life satisfaction scales. Social Indicators Research, 112(3), 497-527. http://dx.doi.org/10.1007/s11205-012-0076-y

Diener, E., Wirtz, D., Tov, W., Kim-Prieto, C., Choi, D., Oishi, S., \& Biswas-Diener, R. (2010). New wellbeing measures: Short scales to assess flourishing and positive and negative feelings. Social Indicators Research, 97(2), 143-156. http://dx.doi.org/10.1007/s11205-009-9493-y

Dunbar, M., Ford, G., Hunt, K., \& Der, G. (2000). Question wording effects in the assessment of global self-esteem. European Journal of Psychological Assessment, 16(1), 13-19. http://dx.doi.org/10.1027//1015$\underline{5759.16 .1 .13}$

Eaton, W. W., Muntaner, C., Smith, C., Tien, A., \& Ybarra, M. (2004). Center for Epidemiologic Studies Depression Scale: Review and revision (CESD and CESD-R). In M. E. Maruish (Ed.), The use of psychological testing for treatment planning and outcomes assessment (3rd ed., pp. 363-377). Mahwah, NJ: Lawrence Erlbaum.

Ford, B. Q., \& Mauss, I. B. (2014). The paradoxical effect of pursuing positive emotions: When and why wanting to be happy backfires. In. J. Gruber \& J. T. Moskowitz (Eds.), Positive emotion: Integrating the light sides and dark sides (pp. 363-381). New York, NY: Oxford University Press. http://dx.doi.org/10.1093/acprof:oso/9780199926725.003.0020

Forgeard, M. J. C., Jayawickreme, E., Kern, M. L., \& Seligman, M. E. P. (2011). Doing the right thing: Measuring well-being for public policy. International Journal of Wellbeing, 1(1), 79-106. http://dx.doi.org/10.5502/ijw.v1i1.15

Friedman, H. S., \& Kern, M. L. (2014). Personality, well-being, and health. Annual Review of Psychology, 65, 719-742. http://dx.doi.org/10.1146/annurev-psych-010213-115123

Hone, L. C., Jarden, A., Schofield, G. M., \& Duncan, S. (2014). Measuring flourishing: The impact of operational definitions on the prevalence of high levels of wellbeing. International Journal of Wellbeing, 4(1), 62-90. http://dx.doi.org/10.5502/ijw.v4i1.1

Howell, R., Kern, M. L., \& Lyubomirsky, S. (2007). Health benefits: Meta-analytically determining the impact of well-being on objective health outcomes. Health Psychology Review, 1(1), 83-136. http://dx.doi.org/10.1080/17437190701492486

Hu, L. T., \& Bentler, P. M. (1999). Cutoff criteria for fit indexes in covariance structure analysis: Conventional criteria versus new alternatives. Structural Equation Modeling, 6(1), 1-55. http://dx.doi.org/10.1080/10705519909540118

Huelsman, T. J., Nemanick, R. C. Jr., \& Munz, D. C. (1998). Scale to measure four dimensions of dispositional mood: Positive energy, tiredness, negative activation, and relaxation. Educational and Psychological Measurement, 58(5), 804-819. http://dx.doi.org/10.1177/0013164498058005006

Huppert, F. A. (2009). Psychological well-being: Evidence regarding its causes and consequences. Applied Psychology: Health and Well-being, 1(2), 137-164. http://dx.doi.org/10.1111/j.1758-0854.2009.01008.x

Huppert, F. A. (2014). The state of well-being science: Concepts, measures, interventions, and policies. In F. A. Huppert \& C. L. Cooper (Eds.), Interventions and policies to enhance well-being. Oxford, England: Wiley-Blackwell.

Huppert, F. A., \& So, T. T. C. (2013). Flourishing across Europe: Application of a new conceptual framework for defining well-being. Social Indicators Research, 110(3), 837-861. http://dx.doi.org/10.1007/s11205-011-9966-7

John, O. P., \& Benet-Martinez, V. (2000). Measurement: Reliability, construct validity, and scale construction. In H. T. Reis \& C. M. Judd (Eds.), Handbook of research methods in social and personality psychology (pp. 339-369). Cambridge, England: Cambridge University Press. 
John, O. P., \& Soto, C. J. (2007). The importance of being valid: Reliability and the process of construct validation. In R. W. Robins, R. C. Fraley, \& R. F. Krueger (Eds.), Handbook of research methods in personality psychology (pp. 461-494). New York, NY: Guildford Press.

Jolliffe, I.T. (2002). Principal components analysis. (2nd ed.). New York, NY: Springer.

Kern, M. L., Waters, L., Adler, A., \& White, M. (2015). A multidimensional approach to measuring wellbeing in students: Application of the PERMA framework. The Journal of Positive Psychology, 10(3), 262-271. http://dx.doi.org/10.1080/17439760.2014.936962

Kern, M. L., Waters, L., White, M., \& Adler, A. (2014). Assessing employee wellbeing in schools using a multifaceted approach: Associations with physical health, life satisfaction, and professional thriving. Psychology, 5(6), 500-513. http://dx.doi.org/10.4236/psych.2014.56060

Keyes, C. L. M. (2002). The mental health continuum: From languishing to flourishing in life. Journal of Health and Social Behavior, 43(2), 207-222. http://dx.doi.org/10.2307/3090197

Lazarus, R. S. (2003). Does the positive psychology movement have legs? Psychological Inquiry, 14(2), 93109. http://dx.doi.org/10.1207/S15327965PLI1402 02

Little, B., Salmela-Aro, K., \& Phillips, S. (2007). Personal project pursuit: Goals, action and human flourishing. Hillsdale, NJ: Lawrence Erlbaum Associates.

Little, D., Linderberger, U., \& Nesselroade, J. R. (1999). On selecting indicators for multivariate measurement and modeling with latent variables: When "good" indicators are bad and "bad" indicators are good. Psychological Methods, 4(2), 192-211. http://dx.doi.org/10.1037/1082-989X.4.2.192

Lyubomirsky, S., King, L. A., \& Diener, E. (2005). The benefits of frequent positive affect: Does happiness lead to success? Psychological Bulletin, 131(6), 803-855. http://dx.doi.org/10.1037/0033-2909.131.6.803

Marsh, H. W. (1986). Negative item bias in ratings scales for preadolescent children: A cognitivedevelopmental phenomenon. Developmental Psychology, 22(1), 37-49. http://dx.doi.org/10.1037/0012$\underline{1649.22 .1 .37}$

Marsh, H. W. (1996). Positive and negative global self-esteem: A substantively meaningful distinction or artifactors? Journal of Personality and Social Psychology, 70(4), 810-819. http://dx.doi.org/10.1037/0022$\underline{3514.70 .4 .810}$

Miller, A. (2008). A critique of positive psychology - or 'the science of happiness'. Journal of Philosophy of Education, 42(3-4), 591-608. http://dx.doi.org/10.1111/j.1467-9752.2008.00646.x

Norrish, J. (2015). Positive education: The Geelong Grammar School journey. Oxford, England: Oxford University Press. http://dx.doi.org/10.1093/acprof:oso/9780198702580.001.0001

Office for National Statistics (2011, December). Initial investigation into subjective well-being from the opinions survey. http://webarchive.nationalarchives.gov.uk/20160105160709/http://www.ons.gov.uk/ons/dcp171776 2 44488.pdf

Oishi, S., \& Schimmack, U. (2010). Culture and well-being: A new inquiry into the psychological wealth of nations. Perspectives on Psychological Science, 5(4), 463-471.

http://dx.doi.org/10.1177/1745691610375561

Organisation for Economic Co-operation and Development (OECD). (2013). OECD Guidelines on Measuring SubjectiveWell-being. Paris, France: OECD Publishing. http://www.oecd.org/statistics/Guidelines\%20on\%20Measuring\%20Subjective\%20Well-being.pdf

Pawelski, J. O. (2013). Happiness and its opposites. In J. O. Pawelski (Ed.), Oxford handbook of happiness. New York, NY: Oxford University Press. http://dx.doi.org/10.1093/oxfordhb/9780199557257.013.0025

Revelle, W. (2015). Package 'psych'. https://cran.r-project.org/web/packages/psych/psych.pdf

Rosseel, Y. (2012). lavaan: An R package for structural equation modeling. Journal of Statistical Software, 48(1), 1-36. http://dx.doi.org/10.18637/jss.v048.i02

Rowe, J. W., \& Kahn, R. L. (1987). Human aging: Usual and successful. Science, 237(4811), 143-149. http://dx.doi.org/10.1126/science.3299702

Rusk, R. D., \& Waters, L. (2015). A psycho-social system approach to well-being: Empirically deriving the five domains of positive functioning. The Journal of Positive Psychology, 10(2), 141-152.

http://dx.doi.org/10.1080/17439760.2014.920409 
Ryan, R. M., \& Deci, E. L. (2000). Self-determination theory and the facilitation of intrinsic motivation, social development, and well-being. American Psychologist, 55(1), 68-78. http://dx.doi.org/10.1037/0003-066X.55.1.68

Ryan, R. M., \& Deci, E. L. (2001). On happiness and human potentials: A review of research on hedonic and eudaimonic wellbeing. Annual Review of Psychology, 52, 141-166. http://dx.doi.org/10.1146/annurev.psych.52.1.141

Ryff, C. D. (2014). Psychological well-being revisited: Advances in the science and practice of eudaimonia. Psychotherapy and Psychosomatics, 83(1), 10-28. http://dx.doi.org/10.1159/000353263

Ryff, C. D., \& Keyes, C. L. M. (1995). The structure of psychological well-being revisited. Journal of Personality and Social Psychology, 69(4), 719-727. http://dx.doi.org/10.1037/0022-3514.69.4.719

Ryff, C. D., Singer, B. H., \& Love, G. D. (2004). Positive health: Connecting well-being with biology. Philosophical Transactions of the Royal Society, 359(1449), 1383-1394. http://dx.doi.org/10.1098/rstb.2004.1521

Schaufeli, W. B., Bakker, A. B., \& Salanova, M. (2006). The measurement of work engagement with a short questionnaire: A cross-national study. Educational and Psychological Measurement, 66(4), $701-716$. http://dx.doi.org/10.1177/0013164405282471

Schwartz, S. H. (2012). An overview of the Schwartz Theory of Basic Values. Online Readings in Psychology and Culture, 2(1). http://dx.doi.org/10.9707/2307-0919.1116

Seligman, M. E. P. (2011). Flourish: A visionary new understanding of happiness and well-being. New York, NY: Free Press.

Shapiro, D. N., Chandler, J., \& Mueller, P. A. (2013). Using Mechanical Turk to study clinical populations. Clinical Psychological Science, 1(2), 213-220. http://dx.doi.org/10.1177/2167702612469015

Steger, M. F. (2012). Experiencing meaning in life: Optimal functioning at the nexus of spirituality, psychopathology, and wellbeing. In P. T. P. Wong (Ed.), The human quest for meaning (2nd ed., pp. 165-184). New York, NY: Routledge.

Stewart-Brown, S., Tennant, A., Tennant, R., Platt, S., Parkinson, J., \& Weich, S. (2009). Internal construct validity of the Warwick-Edinburgh Mental Well-being Scale (WEMWBS): A Rasch analysis using data from the Scottish Health Education Population Survey. Health and Quality of Life Outcomes, 7(15), 1-8. http://dx.doi.org/10.1186/1477-7525-7-15

Su, R., Tay, L., \& Diener, E. (2014). The development and validation of the Comprehensive Inventory of Thriving (CIT) and the Brief Inventory of Thriving (BIT). Applied Psychology: Health and Well-Being, 6(3), 251-279. http://dx.doi.org/10.1111/aphw.12027

Taga, K. A. (2006). The measurement and health outcomes of social support. (Doctoral dissertation). Proquest (ID \# 1273110621).

Tay, L., Tan, K., Diener, E., \& Gonzalez, E. (2012). Social relations, health behaviors, and health outcomes: A survey and synthesis. Applied Psychology: Health and Well-being, 5(1), 28-78. http://dx.doi.org/10.1111/aphw.12000

Taylor, S. E. (2011). Social support: A review. In H. S. Friedman (Ed.), The Oxford handbook of health psychology (pp. 189-214). New York, NY: Oxford University Press. http://dx.doi.org/10.1093/oxfordhb/9780195342819.013.0009

Watson, D., \& Tellegen, A. (1985). Toward a consensual structure of mood. Psychological Bulletin, 98(2), 219-235. http://dx.doi.org/10.1037/0033-2909.98.2.219

Widaman, K. F., Little, T. D., Preacher, K. J., \& Sawalini, G. M. (2011). On creating and using short forms of scales in secondary research. In K. H. Trzesniewski, M. B. Donnellan, \& R. E. Lucas (Eds.), Secondary data analysis: An introduction for psychologists (pp. 39-61). Washington, DC: American Psychological Association. http://dx.doi.org/10.1037/12350-003

Wong, P. T. P. (2011). Positive psychology 2.0: Towards a balanced interactive model of the good life. Canadian Psychology, 52(2), 69-81. http://dx.doi.org/10.1037/a0022511 


\section{Appendix 1. The PERMA item bank}

\begin{tabular}{|c|c|c|c|c|}
\hline Domain & Sub-domain & Question Used & Response Scale & Source \\
\hline Positive Emotion & General positive & Taking all things together, how happy would you say you are? & $\begin{array}{l}0=\text { extremely unhappy, } \\
10=\text { extremely happy }\end{array}$ & ESS \\
\hline Positive Emotion & Recent positive & During the past week, how often have you felt: Positive & $\begin{array}{l}0=\text { never } \\
10=\text { always }\end{array}$ & SPANE \\
\hline Positive Emotion & Recent negative & During the past week, how often have you felt: Negative & $\begin{array}{l}0=\text { never } \\
10=\text { always }\end{array}$ & SPANE \\
\hline Positive Emotion & Recent positive & During the past week, how often have you felt: Good & $\begin{array}{l}0=\text { never }, \\
10=\text { always }\end{array}$ & SPANE \\
\hline Positive Emotion & Recent negative & During the past week, how often have you felt: Bad & $\begin{array}{l}0=\text { never, } \\
10=\text { always }\end{array}$ & SPANE \\
\hline Positive Emotion & Recent positive & During the past week, how often have you felt: Pleasant & $\begin{array}{l}0=\text { never }, \\
10=\text { always }\end{array}$ & SPANE \\
\hline Positive Emotion & Recent negative & During the past week, how often have you felt: Unpleasant & $\begin{array}{l}0=\text { never } \\
10=\text { always }\end{array}$ & SPANE \\
\hline Positive Emotion & Recent positive & During the past week, how often have you felt: Happy & $\begin{array}{l}0=\text { never, } \\
10=\text { always }\end{array}$ & SPANE \\
\hline Positive Emotion & Recent negative & During the past week, how often have you felt: Sad & $\begin{array}{l}0=\text { never }, \\
10=\text { always }\end{array}$ & SPANE \\
\hline Positive Emotion & Recent negative & During the past week, how often have you felt: Afraid & $\begin{array}{l}0=\text { never }, \\
10=\text { always }\end{array}$ & SPANE \\
\hline Positive Emotion & Recent positive & During the past week, how often have you felt: Joyful & $\begin{array}{l}0=\text { never } \\
10=\text { always }\end{array}$ & SPANE \\
\hline Positive Emotion & Recent negative & During the past week, how often have you felt: Angry & $\begin{array}{l}0=\text { never }, \\
10=\text { always }\end{array}$ & SPANE \\
\hline Positive Emotion & Recent positive & During the past week, how often have you felt: Contented & $\begin{array}{l}0=\text { never }, \\
10=\text { always }\end{array}$ & SPANE \\
\hline Positive Emotion & Recent negative & During the past week, how often have you felt: Anxious & $\begin{array}{l}0=\text { never }, \\
10=\text { always }\end{array}$ & ESS \\
\hline Positive Emotion & Recent positive & During the past week, how often have you felt: Cheerful & $\begin{array}{l}0=\text { never }, \\
10=\text { always }\end{array}$ & WEMWBS \\
\hline
\end{tabular}




\begin{tabular}{|c|c|c|c|c|}
\hline Domain & Sub-domain & Question Used & Response Scale & Source \\
\hline Positive Emotion & Recent positive & During the past week, how often have you felt: Relaxed & $\begin{array}{l}0=\text { never } \\
10=\text { always }\end{array}$ & WEMWBS \\
\hline Positive Emotion & Recent negative & During the past week, how often have you felt: Nervous & $\begin{array}{l}0=\text { never, } \\
10=\text { always }\end{array}$ & PANAS \\
\hline Positive Emotion & General positive & In general, how often do you feel: Positive & $\begin{array}{l}0=\text { never }, \\
10=\text { always }\end{array}$ & SPANE \\
\hline Positive Emotion & General negative & In general, how often do you feel: Negative & $\begin{array}{l}0=\text { never, } \\
10=\text { always }\end{array}$ & SPANE \\
\hline Positive Emotion & General positive & In general, how often do you feel: Good & $\begin{array}{l}0=\text { never, } \\
10=\text { always }\end{array}$ & SPANE \\
\hline Positive Emotion & General negative & In general, how often do you feel: Bad & $\begin{array}{l}0=\text { never } \\
10=\text { always }\end{array}$ & SPANE \\
\hline Positive Emotion & General positive & In general, how often do you feel: Pleasant & $\begin{array}{l}0=\text { never, } \\
10=\text { always }\end{array}$ & SPANE \\
\hline Positive Emotion & General negative & In general, how often do you feel: Unpleasant & $\begin{array}{l}0=\text { never } \\
10=\text { always }\end{array}$ & SPANE \\
\hline Positive Emotion & General positive & In general, how often do you feel: Happy & $\begin{array}{l}0=\text { never, } \\
10=\text { always }\end{array}$ & SPANE \\
\hline Positive Emotion & General negative & In general, how often do you feel: Sad & $\begin{array}{l}0=\text { never, } \\
10=\text { always }\end{array}$ & SPANE \\
\hline Positive Emotion & General negative & In general, how often do you feel: Afraid & $\begin{array}{l}0=\text { never, } \\
10=\text { always }\end{array}$ & SPANE \\
\hline Positive Emotion & General positive & In general, how often do you feel: Joyful & $\begin{array}{l}0=\text { never, } \\
10=\text { always }\end{array}$ & SPANE \\
\hline Positive Emotion & General negative & In general, how often do you feel: Angry & $\begin{array}{l}0=\text { never, } \\
10=\text { always }\end{array}$ & SPANE \\
\hline Positive Emotion & General positive & In general, how often do you feel: Contented & $\begin{array}{l}0=\text { never, } \\
10=\text { always }\end{array}$ & SPANE \\
\hline Positive Emotion & General negative & In general, how often do you feel: Anxious & $\begin{array}{l}0=\text { never } \\
10=\text { always }\end{array}$ & ESS \\
\hline Positive Emotion & General positive & In general, how often do you feel: Cheerful & $\begin{array}{l}0=\text { never } \\
10=\text { always }\end{array}$ & WEMWBS \\
\hline
\end{tabular}




\begin{tabular}{|c|c|c|c|c|}
\hline Domain & Sub-domain & Question Used & Response Scale & Source \\
\hline Positive Emotion & General positive & In general, how often do you feel: Relaxed & $\begin{array}{l}0=\text { never } \\
10=\text { always }\end{array}$ & WEMWBS \\
\hline Positive Emotion & General negative & In general, how often do you feel: Nervous & $\begin{array}{l}0=\text { never } \\
10=\text { always }\end{array}$ & PANAS \\
\hline Engagement & Absorption & $\begin{array}{l}\text { How much of the time during the past week were you absorbed } \\
\text { in what you were doing? }\end{array}$ & $\begin{array}{l}0=\text { none of the time, } \\
10=\text { all of the time }\end{array}$ & ESS \\
\hline Engagement & Absorption & $\begin{array}{l}\text { How much of the time do you become absorbed in what you are } \\
\text { doing? }\end{array}$ & $\begin{array}{l}0=\text { none of the time, } \\
10=\text { all of the time }\end{array}$ & ESS \\
\hline Engagement & Absorption & $\begin{array}{l}\text { How much of the time do you lose track of time while doing } \\
\text { something you enjoy? }\end{array}$ & $\begin{array}{l}0=\text { none of the time, } \\
10=\text { all of the time }\end{array}$ & ESS \\
\hline Engagement & Absorption & $\begin{array}{l}\text { How much of the time during the past week were you absorbed } \\
\text { in something you enjoyed doing? }\end{array}$ & $\begin{array}{l}0=\text { none of the time, } \\
10=\text { all of the time }\end{array}$ & ESS \\
\hline Engagement & Absorption & $\begin{array}{l}\text { How much of the time do you do things that you find interesting } \\
\text { or challenging? }\end{array}$ & $\begin{array}{l}0=\text { none of the time, } \\
10=\text { all of the time }\end{array}$ & ESS \\
\hline Engagement & Absorption & $\begin{array}{l}\text { In general, how often do you find that you become completely } \\
\text { engrossed in something? }\end{array}$ & $\begin{array}{l}0=\text { never } \\
10=\text { always }\end{array}$ & Flow \\
\hline Engagement & Absorption & $\begin{array}{l}\text { To what extent do you become unaware of what is going on } \\
\text { around you when engaged in activities that are important to } \\
\text { you? }\end{array}$ & $0=$ not at all, $10=$ completely & Lab \\
\hline Engagement & Effort & $\begin{array}{l}\text { How much effort do you generally devote to the things that are } \\
\text { important to you? }\end{array}$ & $0=$ none at all, $10=$ complete & Engagement \\
\hline Engagement & Effort & $\begin{array}{l}\text { How much attention do you generally focus on the things that } \\
\text { are important to you? }\end{array}$ & $0=$ none at all, $10=$ complete & Engagement \\
\hline Engagement & Effort & $\begin{array}{l}\text { How much energy do you generally give to the things that are } \\
\text { important to you? }\end{array}$ & $0=$ none at all, $10=$ complete & Engagement \\
\hline Engagement & Effort & How challenging for you are the activities you are involved in? & $0=$ not at all, $10=$ extremely & Lab \\
\hline Engagement & Effort & $\begin{array}{l}\text { In general, how often do you exert your full effort on the } \\
\text { activities you engage in? }\end{array}$ & $\begin{array}{l}0=\text { never } \\
10=\text { always }\end{array}$ & Lab \\
\hline Engagement & Interest & $\begin{array}{l}\text { How much of the time are you really interested in what you are } \\
\text { doing? }\end{array}$ & $\begin{array}{l}0=\text { none of the time, } \\
10=\text { all of the time }\end{array}$ & AHI \\
\hline Engagement & Interest & $\begin{array}{l}\text { How much of the time during the past week have you felt } \\
\text { bored? }\end{array}$ & $\begin{array}{l}0=\text { none of the time, } \\
10=\text { all of the time }\end{array}$ & ESS \\
\hline Engagement & Interest & How engaged and interested are you in your daily activities? & $0=$ not at all, $10=$ extremely & FS \\
\hline
\end{tabular}




\begin{tabular}{|c|c|c|c|c|}
\hline Domain & Sub-domain & Question Used & Response Scale & Source \\
\hline Engagement & Interest & $\begin{array}{l}\text { During the past week, to what extent did you feel particularly } \\
\text { excited or interested in something? }\end{array}$ & $0=$ not at all, $10=$ extremely & ABS \\
\hline Engagement & Interest & $\begin{array}{l}\text { In general, to what extent do you feel particularly excited or } \\
\text { interested in things? }\end{array}$ & $0=$ not at all, $10=$ extremely & ABS \\
\hline Engagement & Interest & To what extent do you love learning new things? & $\begin{array}{l}0=\text { not at all, } \\
10=\text { a great deal }\end{array}$ & ESS \\
\hline Engagement & Involvement & $\begin{array}{l}\text { During the past week, to what extent have you been managing } \\
\text { to keep yourself busy and occupied? }\end{array}$ & $\begin{array}{l}0=\text { not at all, } \\
10=\text { extremely }\end{array}$ & GHQ-30 \\
\hline Engagement & Involvement & $\begin{array}{l}\text { To what extent would you describe yourself as committed and } \\
\text { involved? }\end{array}$ & $\begin{array}{l}0=\text { not at all, } \\
10=\text { a great deal }\end{array}$ & $\mathrm{OHI}$ \\
\hline Engagement & Involvement & How involved are you in activities that are important to you? & $0=$ not at all, $10=$ extremely & $\mathrm{Lab}$ \\
\hline Engagement & Involvement & $\begin{array}{l}\text { In general, how often do you participate in activities that are } \\
\text { important to you? }\end{array}$ & $\begin{array}{l}0=\text { never, } \\
10=\text { always }\end{array}$ & $\mathrm{Lab}$ \\
\hline Engagement & Involvement & How much of the time do you spend doing things you enjoy? & $\begin{array}{l}0=\text { none of the time, } \\
10=\text { all of the time }\end{array}$ & Lab \\
\hline Relationships & Giving & In general, to what extent are you a giving person? & $0=$ not at all, $10=$ extremely & SPWB \\
\hline Relationships & Giving & $\begin{array}{l}\text { To what extent are you willing to give of your time to others in } \\
\text { need? }\end{array}$ & $\begin{array}{l}0=\text { not at all, } \\
10=\text { a great deal }\end{array}$ & SPWB \\
\hline Relationships & Giving & $\begin{array}{l}\text { How satisfied are you with your ability to provide support for } \\
\text { others? }\end{array}$ & $\begin{array}{l}0=\text { extremely dissatisfied, } \\
10=\text { extremely satisfied }\end{array}$ & WHO-QOL 100 \\
\hline Relationships & Giving & $\begin{array}{l}\text { To what extent do you actively contribute to the happiness and } \\
\text { wellbeing of others? }\end{array}$ & $\begin{array}{l}0=\text { not at all, } \\
10=\text { a great deal }\end{array}$ & FS \\
\hline Relationships & Giving & $\begin{array}{l}\text { To what extent do you provide help and support to others when } \\
\text { they need it? }\end{array}$ & $\begin{array}{l}0=\text { not at all, } \\
10=\text { a great deal }\end{array}$ & ESS \\
\hline Relationships & Embedded & How well do you generally get on with people around you? & $0=$ not at all, $10=$ extremely & ONS \\
\hline Relationships & Embedded & How satisfied are you with your personal relationships? & $\begin{array}{l}0=\text { extremely dissatisfied, } \\
10=\text { extremely satisfied }\end{array}$ & WHO-QOL 100 \\
\hline Relationships & Embedded & $\begin{array}{l}\text { In general, how often do you meet or talk with family and } \\
\text { friends? }\end{array}$ & $\begin{array}{l}0=\text { never } \\
10=\text { always }\end{array}$ & ISEL \\
\hline Relationships & Embedded & $\begin{array}{l}\text { In general, to what extent has maintaining close relationships } \\
\text { been difficult for you? }\end{array}$ & $0=$ not at all, $10=$ extremely & SPWB \\
\hline Relationships & Embedded & $\begin{array}{l}\text { How much of the time during the past week have you been } \\
\text { feeling close to other people? }\end{array}$ & $\begin{array}{l}0=\text { none of the time, } \\
10=\text { all of the time }\end{array}$ & WEMWBS \\
\hline
\end{tabular}




\begin{tabular}{|c|c|c|c|c|}
\hline Domain & Sub-domain & Question Used & Response Scale & Source \\
\hline Relationships & Embedded & $\begin{array}{l}\text { How many close friends do you have? Please also include } \\
\text { members of your family you consider to be close friends. }\end{array}$ & $\begin{array}{l}\text { Text box, type in the } \\
\text { number }\end{array}$ & ESS \\
\hline Relationships & Perceived & To what extent have you been feeling loved? & $0=$ not at all, $10=$ completely & WEMWBS \\
\hline Relationships & Perceived & $\begin{array}{l}\text { To what extent do you feel that there are people in your life who } \\
\text { really care about you? }\end{array}$ & $\begin{array}{l}0=\text { not at all, } \\
10=\text { a great deal }\end{array}$ & ESS \\
\hline Relationships & Perceived & To what extent do you feel appreciated by the people you know? & $0=$ not at all, $10=$ completely & ONS \\
\hline Relationships & Perceived & To what extent do you feel that people treat you with respect? & $0=$ not at all, $10=$ completely & ONS \\
\hline Relationships & Perceived & How lonely do you feel in your daily life? & $0=$ not at all, $10=$ extremely & ONS \\
\hline Relationships & Perceived & $\begin{array}{l}\text { To what extent do you feel that there is no one with whom you } \\
\text { can share your most private worries and fears? }\end{array}$ & $\begin{array}{l}0=\text { not at all, } \\
10=\text { a great deal }\end{array}$ & ISEL \\
\hline Relationships & Perceived & $\begin{array}{l}\text { To what extent do you feel you have someone with whom you } \\
\text { can discuss intimate and personal matters? }\end{array}$ & $\begin{array}{l}0=\text { not at all, } \\
10=\text { a great deal }\end{array}$ & ESS \\
\hline Relationships & Perceived & How supportive and rewarding are your social relationships? & $0=$ not at all, $10=$ extremely & FS \\
\hline Relationships & Perceived & $\begin{array}{l}\text { To what extent do you receive help and support from others } \\
\text { when you need it? }\end{array}$ & $\begin{array}{l}0=\text { not at all, } \\
10=\text { a great deal }\end{array}$ & ESS \\
\hline Relationships & Perceived & $\begin{array}{l}\text { How satisfied are you with the support that you get from } \\
\text { others? }\end{array}$ & $\begin{array}{l}0=\text { extremely dissatisfied, } \\
10=\text { extremely satisfied }\end{array}$ & WHO-QOL 100 \\
\hline Meaning & Worth & $\begin{array}{l}\text { In general, to what extent do your daily activities seem trivial } \\
\text { and unimportant? }\end{array}$ & $0=$ not at all, $10=$ extremely & SPWB \\
\hline Meaning & Worth & $\begin{array}{l}\text { In general, to what extent do you feel what you do in your life is } \\
\text { valuable and worthwhile? }\end{array}$ & $0=$ not at all, $10=$ extremely & ESS \\
\hline Meaning & Worth & $\begin{array}{l}\text { In general, to what extent do you feel that what you do in your } \\
\text { daily activities is valuable and worthwhile? }\end{array}$ & $0=$ not at all, $10=$ extremely & ESS \\
\hline Meaning & Worth & $\begin{array}{l}\text { How useful a role do you feel you play in the world around } \\
\text { you? }\end{array}$ & $0=$ not at all, $10=$ extremely & ONS \\
\hline Meaning & Worth & $\begin{array}{l}\text { How much of the time during the past week have you been } \\
\text { feeling useful? }\end{array}$ & $\begin{array}{l}0=\text { none of the time, } \\
10=\text { all of the time }\end{array}$ & WEMWBS \\
\hline Meaning & Transcendent & Has your life had a very clear goal or purpose? & $\begin{array}{l}0=\text { no clear goal or purpose, } \\
10=\text { a very clear goal or } \\
\text { purpose }\end{array}$ & SOC \\
\hline Meaning & Transcendent & $\begin{array}{l}\text { During the past week, to what extent have you been feeling } \\
\text { inspired? }\end{array}$ & $0=$ not at all, $10=$ extremely & PANAS \\
\hline Meaning & Transcendent & To what extent do you have a sense of purpose in what you do? & $0=$ not at all, $10=$ completely & GAT \\
\hline
\end{tabular}




\begin{tabular}{|c|c|c|c|c|}
\hline Domain & Sub-domain & Question Used & Response Scale & Source \\
\hline Meaning & Transcendent & To what extent do you live your life with purpose? & $0=$ not at all, $10=$ completely & $\mathrm{Lab}$ \\
\hline Meaning & Transcendent & $\begin{array}{l}\text { In general, to what extent do you lead a purposeful and } \\
\text { meaningful life? }\end{array}$ & $0=$ not at all, $10=$ extremely & FS \\
\hline Meaning & Direction & $\begin{array}{l}\text { To what extent do you live in accordance with your values and } \\
\text { beliefs? }\end{array}$ & $0=$ not at all, $10=$ completely & Lab \\
\hline Meaning & Direction & $\begin{array}{l}\text { To what extent do you generally feel you have a sense of } \\
\text { direction in your life? }\end{array}$ & $0=$ none at all, $10=$ complete & ONS \\
\hline Meaning & Direction & To what extent do you plan and prepare for the future? & $\begin{array}{l}0=\text { not at all, } \\
10=\text { a great deal }\end{array}$ & ESS \\
\hline Meaning & Direction & $\begin{array}{l}\text { To what extent do you like planning and preparing for the } \\
\text { future? }\end{array}$ & $\begin{array}{l}0=\text { not at all, } \\
10=\text { a great deal }\end{array}$ & ESS \\
\hline Meaning & Direction & $\begin{array}{l}\text { To what extent do you have personal projects or goals that you } \\
\text { feel it is important for you to pursue? }\end{array}$ & $\begin{array}{l}0=\text { not at all, } \\
10=\text { a great deal }\end{array}$ & $\mathrm{Lab}$ \\
\hline Accomplishment & Goals & How easy is it for you to stick to your aims? & $0=$ not at all, $10=$ extremely & GSE \\
\hline Accomplishment & Goals & $\begin{array}{l}\text { How much of the time do you feel you are making progress } \\
\text { towards accomplishing your goals? }\end{array}$ & $\begin{array}{l}0=\text { none of the time, } \\
10=\text { all of the time }\end{array}$ & GSE \\
\hline Accomplishment & Goals & $\begin{array}{l}\text { To what extent do you accomplish the things you set out to do in } \\
\text { your daily activities? }\end{array}$ & $\begin{array}{l}0=\text { not at all, } \\
10=\text { a great deal }\end{array}$ & SPWB \\
\hline Accomplishment & Goals & $\begin{array}{l}\text { How much of the time do you achieve the important goals you } \\
\text { have set for yourself? }\end{array}$ & $\begin{array}{l}0=\text { none of the time, } \\
10=\text { all of the time }\end{array}$ & Lab \\
\hline Accomplishment & Goals & $\begin{array}{l}\text { How much of the time are you successful in achieving the goals } \\
\text { you set for yourself? }\end{array}$ & $\begin{array}{l}0=\text { none of the time, } \\
10=\text { all of the time }\end{array}$ & $\mathrm{Lab}$ \\
\hline Accomplishment & Efficacy & $\begin{array}{l}\text { To what extent can you usually handle whatever comes your } \\
\text { way? }\end{array}$ & $\begin{array}{l}0=\text { handle extremely poorly, } \\
10=\text { handle extremely well }\end{array}$ & GSE \\
\hline Accomplishment & Efficacy & $\begin{array}{l}\text { How much of the time are you able to handle your } \\
\text { responsibilities? }\end{array}$ & $\begin{array}{l}0=\text { none of the time, } \\
10=\text { all of the time }\end{array}$ & SPWB \\
\hline Accomplishment & Efficacy & $\begin{array}{l}\text { In general, to what extent do you feel able to deal with important } \\
\text { problems in your life? }\end{array}$ & $0=$ not at all, $10=$ extremely & ONS \\
\hline Accomplishment & Efficacy & $\begin{array}{l}\text { In your daily life, how much opportunity do you feel you have } \\
\text { to show how capable you are? }\end{array}$ & $\begin{array}{l}0=\text { no opportunity at all, } 10=a \\
\text { great deal of opportunity }\end{array}$ & ONS \\
\hline Accomplishment & Efficacy & $\begin{array}{l}\text { To what extent do you feel you can do just about anything you } \\
\text { really set your mind to? }\end{array}$ & $\begin{array}{l}0=\text { not at all, } \\
10=\text { a great deal }\end{array}$ & SMS \\
\hline
\end{tabular}




\begin{tabular}{|c|c|c|c|c|}
\hline Domain & Sub-domain & Question Used & Response Scale & Source \\
\hline Accomplishment & Efficacy & $\begin{array}{l}\text { In general, to what extent are you competent and capable in the } \\
\text { activities that are important to you? }\end{array}$ & $0=$ not at all, $10=$ extremely & FS \\
\hline Accomplishment & Subjective & $\begin{array}{l}\text { During the past week, to what extent did you feel pleased about } \\
\text { having accomplished something? }\end{array}$ & $0=$ not at all, $10=$ extremely & ABS \\
\hline Accomplishment & Subjective & $\begin{array}{l}\text { How much of the time do you feel a sense of accomplishment } \\
\text { from what you do? }\end{array}$ & $\begin{array}{l}0=\text { none } \mathrm{o} \\
10=\text { all of }\end{array}$ & ESS \\
\hline Accomplishment & Subjective & $\begin{array}{l}\text { To what extent do you feel a sense of accomplishment from the } \\
\text { things you do in your daily life? }\end{array}$ & $0=$ none at all, $10=$ complete & ONS \\
\hline Accomplishment & Subjective & $\begin{array}{l}\text { To what extent do you feel a sense of accomplishment from the } \\
\text { things you have achieved in your life up until now? }\end{array}$ & $11,10=$ complete & $\mathrm{Lab}$ \\
\hline Accomplishment & Subjective & $\begin{array}{l}\text { In general, to what extent do you feel proud of what you have } \\
\text { achieved? }\end{array}$ & $0=$ not at all, $10=$ extremely & PANAS \\
\hline Accomplishment & Subjective & $\begin{array}{l}\text { To what extent do you feel disappointed about your } \\
\text { achievements in life? }\end{array}$ & $\begin{array}{l}0=\text { not at all, } \\
10=\text { a great deal }\end{array}$ & SPWB \\
\hline \multicolumn{5}{|c|}{$\begin{array}{l}\text { Note. ABS = Affect Balance Scale (Bradburn, 1969); AHI = Authentic Happiness Inventory (Seligman, 2002); Engagement = Engagement (Rich, LePine, \& Crawford, 2010); ESS = } \\
\text { European Social Survey (Huppert, et al., 2009); Flow = Flow Questionnaire (Csikszentmihalyi \& Csikszentmihalyi, 1988); FS = Flourishing Scale (Diener, et. al., 2010); GAT = Global } \\
\text { Assessment Tool (Peterson, Park \& Castro, 2011); GHQ-30 = General Health Questionnaire (Goldberg, 1972); GSE = Generalized Self-Efficacy Scale (Schwarzer \& Jerusalem, 1995); } \\
\text { ISEL = Interpersonal Support Evaluation List (Cohen \& Hoberman, 1983); Lab = Lab Generated Questions; OHI = Oxford Happiness Inventory (Hills \& Argyle, 2001); ONS = UK } \\
\text { Office for National Statistics Experimental Opinion Survey Questions (Office for National Statistics, 2011); PANAS = Positive and Negative Affect Schedule (Watson, Clark \& } \\
\text { Tellegen, 1988): SMS = Self-Mastery Scale (Pearlin \& Schooler, 1978); SOC = Sense of Coherence (Antonovsky, 1987); SPANE = Scale of Positive and Negative Experience (Diener, } \\
\text { et. al., 2010); SPWB = Scales of Psychological Well-Being (Ryff \& Keyes, 1995); WEMWBS = Warwick-Edinburgh Mental Well-being Scale (Stewart-Brown, et al., 2009); and WHO- } \\
\text { QOL } 100 \text { = World Health Organization Quality of Life (Power, et al., 1998). }\end{array}$} \\
\hline
\end{tabular}




\section{Appendix 1 References}

Antonovsky, A. (1987). Unraveling the mystery of health: How people manage stress and stay well. San Francisco, CA: Joseey-Bass.

Bradburn, N. M. (1969). The structure of psychological well-being. Chicago, IL: Aldine.

Cohen, S., \& Hoberman, H. M. (1983). Positive events and social supports as buffers of life change stress. Journal of Applied Social Psychology, 13(2), 99-125. http://dx.doi.org/10.1111/j.1559-1816.1983.tb02325.x

Csikszentmihalyi, M., \& Csikszentmihalyi, I. (1988). Optimal experience: Psychological studies of flow in consciousness. Cambridge, England. Cambridge University Press.

http://dx.doi.org/10.1017/cbo9780511621956

Diener, E., Wirtz, D., Tov, W., Kim-Prieto, C., Choi, D., Oishi, S., \& Biswas-Diener, R. (2010). New wellbeing measures: Short scales to assess flourishing and positive and negative feelings. Social Indicators Research, 97(2), 143-156. http://dx.doi.org/10.1007/s11205-009-9493-y

Goldberg, D. P. (1972). The detection of psychiatric illness by questionnaire. London, England: Oxford University Press.

Hills, P., \& Argyle, M. (2001). Emotional stability as a major dimension of happiness. Personality and Individual Differences, 31(8), 1357-1364. http://dx.doi.org/10.1016/S0191-8869(00)00229-4

Huppert, F. A., Marks, N., Clark, A., Siegrist, J., Stutzer, A., Vitterso, J., \& Wahrendorf, M. (2009). Measuring well-being across Europe: Description of the ESS Well-being Module and preliminary findings. Social Indicators Research, 91(3), 301-315. http://dx.doi.org/10.1007/s11205-008-9346-0

Office for National Statistics (2011, December). Initial investigation into subjective well-being from the opinions survey. http://webarchive.nationalarchives.gov.uk/20160105160709/http://www.ons.gov.uk/ons/dcp171776 2 44488.pdf

Pearlin, L. I., \& Schooler, C. (1978). Structure of coping. Journal of Health and Social Behavior, 19(1), 2-21. http://dx.doi.org/10.2307/2136319

Peterson, C., Park, N., \& Castro, C. A. (2011). Assessment for the U.S. Army Comprehensive Soldier Fitness program: The Global Assessment Tool. American Psychologist, 66(1), 10-18. http://dx.doi.org/10.1037/a0021658

Power, M., Kuyken, W., Orley, J., Herrman, H., Schofield, H., Murphy, B., .. S Sartorius, N. (1998). The World Health Organization Quality of Life assessment (WHOQOL): Development and general psychometric properties. Social Science \& Medicine, 46, 1569-1585. http://dx.doi.org/10.1016/S0277-9536(98)00009-4

Rich, B. L., Lepine, J. A., \& Crawford, E. R. (2010). Job engagement: Antecedents and effects on job performance. Academy of Management Journal, 53(3), 617-635. http://dx.doi.org/10.5465/AMJ.2010.51468988

Ryff, C. D., \& Keyes, C. L. M. (1995). The structure of psychological well-being revisited. Journal of Personality and Social Psychology, 69(4), 719-727. http://dx.doi.org/10.1037/0022-3514.69.4.719

Schwarzer, R., \& Jerusalem, M. (1995). Generalized self-efficacy scale. In J. Weinman, S. Wright, \& M. Johnston (Eds.), Measures in health psychology: A user's portfolio, causal and control beliefs (pp. 35-37). Windsor, England: Nfer-Nelson.

Seligman, M. E. P. (2002). Authentic happiness. New York, NY: Free Press.

Stewart-Brown, S., Tennant, A., Tennant, R., Platt, S., Parkinson, J., \& Weich, S. (2009). Internal construct validity of the Warwick-Edinburgh Mental Well-being Scale (WEMWBS): A Rasch analysis using data from the Scottish Health Education Population Survey. Health and Quality of Life Outcomes, 7(15), 1-8. http://dx.doi.org/10.1186/1477-7525-7-15

Watson, D., Clark, L., \& Tellegen, A. (1988). Development and validation of brief measures of positive and negative affect: The PANAS. Journal of Personality and Social Psychology, 54(6), 1063-1070. http://dx.doi.org/10.1037/0022-3514.54.6.1063 


\section{Appendix 2. PERMA correlations with other variables by sample}

\begin{tabular}{|c|c|c|c|c|c|c|c|c|c|c|c|c|c|}
\hline & $\mathbf{N}$ & Mean & SD & Min & Max & $\mathbf{P}$ & $\mathbf{E}$ & $\mathbf{R}$ & $\mathbf{M}$ & A & Overall & NE & $\mathbf{H}$ \\
\hline \multicolumn{14}{|c|}{ Sample 1a (Development sample subset 1) } \\
\hline Positive emotion & 1824 & 6.56 & 1.95 & 0.00 & 10.00 & & & & & & & & \\
\hline Engagement & 1820 & 7.44 & 1.86 & 0.00 & 10.00 & $.59^{* *}$ & & & & & & & \\
\hline Relationships & 1824 & 6.74 & 2.31 & 0.00 & 10.00 & $.61^{* *}$ & $.49^{* *}$ & & & & & & \\
\hline Meaning & 1820 & 6.94 & 2.45 & 0.00 & 10.00 & $.71^{* *}$ & $.68^{* *}$ & $.65^{* *}$ & & & & & \\
\hline Accomplishment & 1820 & 7.15 & 1.90 & 0.00 & 10.00 & $.62^{* *}$ & $.64^{* *}$ & $.55^{* *}$ & $.72^{* *}$ & & & & \\
\hline Overall wellbeing & 1837 & 6.94 & 1.78 & 0.00 & 10.00 & $.84^{* *}$ & $.79^{* *}$ & $.81^{* *}$ & $.91^{* *}$ & $.83^{* *}$ & & & \\
\hline Negative emotion & 1818 & 3.97 & 2.11 & 0.00 & 10.00 & $-.51^{* *}$ & $-.33^{* *}$ & $-.43^{* *}$ & $-.47^{* *}$ & $-.44^{* *}$ & $-.53^{* *}$ & & \\
\hline Physical health a & 1757 & 3.50 & 0.99 & 1.00 & 5.00 & $.37^{* *}$ & $.30^{* *}$ & $.34^{* *}$ & $.35^{* *}$ & $.42^{* *}$ & $.43^{* *}$ & $-.31^{* *}$ & \\
\hline Loneliness $^{\mathrm{b}}$ & 1804 & 4.37 & 3.31 & 0.00 & 10.00 & $-.39^{* *}$ & $-.29^{* *}$ & $-.58^{* *}$ & $-.43^{* *}$ & $-.37^{* *}$ & $-.51^{* *}$ & $.42^{* *}$ & $-.24^{* *}$ \\
\hline Depression ${ }^{c}$ & 1768 & 15.41 & 5.75 & 8.00 & 32.00 & $-.65^{* *}$ & $-.51^{* *}$ & $-.65^{* *}$ & $-.66^{* *}$ & $-.57^{* *}$ & $-.74^{* *}$ & $.62^{* *}$ & $-.42^{* *}$ \\
\hline Life satisfaction ${ }^{d}$ & 1787 & 22.74 & 7.86 & 5.00 & 35.00 & $.65^{* *}$ & $.51^{* *}$ & $.68^{* *}$ & $.72^{* *}$ & $.63^{* *}$ & $.78^{* *}$ & $-.50^{* *}$ & $.42^{* *}$ \\
\hline Flourishing e & 1755 & 43.25 & 9.35 & 11.00 & 56.00 & $.65^{* *}$ & $.59^{* *}$ & $.67^{* *}$ & $.78^{* *}$ & $.67^{* *}$ & $.81^{* *}$ & $-.48^{* *}$ & $.38^{* *}$ \\
\hline WEMWBS f & 1740 & 25.12 & 5.16 & 7.00 & 35.00 & $.67^{* *}$ & $.59^{* *}$ & $.67^{* *}$ & $.73^{* *}$ & $.65^{* *}$ & $.80^{* *}$ & $-.57^{* *}$ & $.43^{* *}$ \\
\hline PAC-10 g & 1720 & 75.77 & 18.88 & 10.00 & 110.00 & $.67^{* *}$ & $.60^{* *}$ & $.65^{* *}$ & $.77^{* *}$ & $.66^{* *}$ & $.81^{* *}$ & $-.51^{* *}$ & $.40^{* *}$ \\
\hline \multicolumn{14}{|c|}{ Sample $\mathbf{1 b}$ (Development sample subset 2) } \\
\hline Positive emotion & 1828 & 6.56 & 1.95 & 0.00 & 10.00 & & & & & & & & \\
\hline Engagement & 1826 & 7.45 & 1.82 & 0.00 & 10.00 & $.59^{* *}$ & & & & & & & \\
\hline Relationships & 1830 & 6.80 & 2.32 & 0.00 & 10.00 & $.61^{* *}$ & $.52^{* *}$ & & & & & & \\
\hline Meaning & 1828 & 6.97 & 2.45 & 0.00 & 10.00 & $.69^{* *}$ & $.68^{* *}$ & $.64^{* *}$ & & & & & \\
\hline Accomplishment & 1824 & 7.11 & 1.98 & 0.00 & 10.00 & $.60^{* *}$ & $.64^{* *}$ & $.57^{* *}$ & $.74^{* *}$ & & & & \\
\hline Overall wellbeing & 1845 & 6.95 & 1.79 & 0.00 & 10.00 & $.83^{* *}$ & $.80^{* *}$ & $.81^{* *}$ & $.90^{* *}$ & $.84^{* *}$ & & & \\
\hline Negative emotion & 1824 & 3.89 & 2.05 & 0.00 & 10.00 & $-.53^{* *}$ & $-.34^{* *}$ & $-.42^{* *}$ & $-.48^{* *}$ & $-.45^{* *}$ & $-.54^{* *}$ & & \\
\hline Physical health a & 1776 & 3.48 & 0.99 & 1.00 & 5.00 & $.35^{* *}$ & $.30^{* *}$ & $.33^{* *}$ & $.38^{* *}$ & $.42^{* *}$ & $.43^{* *}$ & $-.31^{* *}$ & \\
\hline Loneliness ${ }^{\mathrm{b}}$ & 1814 & 4.28 & 3.29 & 0.00 & 10.00 & $-.43^{* *}$ & $-.32^{* *}$ & $-.56^{* *}$ & $-.45^{* *}$ & $-.38^{* *}$ & $-.52^{* *}$ & $.42^{* *}$ & $-.25^{* *}$ \\
\hline Depression $^{c}$ & 1760 & 15.22 & 5.66 & 8.00 & 32.00 & $-.65^{* *}$ & $-.52^{* *}$ & $-.63^{* *}$ & $-.67^{* *}$ & $-.60^{* *}$ & $-.75^{* *}$ & $.61^{* *}$ & $-.41^{* *}$ \\
\hline Life satisfaction $\mathrm{d}$ & 1780 & 22.94 & 7.76 & 5.00 & 35.00 & $.66^{* *}$ & $.54^{* *}$ & $.69^{* *}$ & $.74^{* *}$ & $.65^{* *}$ & $.80^{* *}$ & $-.49^{* *}$ & $.42^{* *}$ \\
\hline Flourishing e & 1764 & 43.55 & 9.56 & 8.00 & 56.00 & $.66^{* *}$ & $.63^{* *}$ & $.65^{* *}$ & $.79^{* *}$ & $.68^{* *}$ & $.82^{* *}$ & $-.46^{* *}$ & $.39^{* *}$ \\
\hline WEMWBS ${ }^{\mathrm{f}}$ & 1757 & 25.17 & 5.26 & 7.00 & 35.00 & $.67^{* *}$ & $.62^{* *}$ & $.68^{* *}$ & $.74^{* *}$ & $.67^{* *}$ & $.81^{* *}$ & $-.56^{* *}$ & $.42^{* *}$ \\
\hline PAC-10g & 1738 & 75.87 & 18.95 & 10.00 & 110.00 & $.64^{* *}$ & $.64^{* *}$ & $.64^{* *}$ & $.75^{* *}$ & $.67^{* *}$ & $.80^{* *}$ & $-.49^{* *}$ & $.40^{* *}$ \\
\hline
\end{tabular}




\begin{tabular}{|c|c|c|c|c|c|c|c|c|c|c|c|c|c|}
\hline & $\mathbf{N}$ & Mean & SD & Min & $\operatorname{Max}$ & $\mathbf{P}$ & E & $\mathbf{R}$ & $\mathbf{M}$ & $\mathbf{A}$ & Overall & NE & $\mathbf{H}$ \\
\hline \multicolumn{14}{|c|}{ Sample 2 (Validation sample) } \\
\hline Positive emotion & 2938 & 6.51 & 2.00 & 0.00 & 10.00 & & & & & & & & \\
\hline Engagement & 2946 & 7.36 & 1.92 & 0.00 & 10.00 & $.60^{* *}$ & & & & & & & \\
\hline Relationships & 2954 & 6.66 & 2.39 & 0.00 & 10.00 & $.61^{* *}$ & $.51^{* *}$ & & & & & & \\
\hline Meaning & 2948 & 6.83 & 2.50 & 0.00 & 10.00 & $.68^{* *}$ & $.69^{* *}$ & $.63^{* *}$ & & & & & \\
\hline Accomplishment & 2947 & 7.06 & 2.01 & 0.00 & 10.00 & $.60^{* *}$ & $.66^{* *}$ & $.55^{* *}$ & $.73^{* *}$ & & & & \\
\hline Overall wellbeing & 2976 & 6.85 & 1.84 & 0.25 & 10.00 & $.84^{* *}$ & $.81^{* *}$ & $.80^{* *}$ & $.90^{* *}$ & $.84^{* *}$ & & & \\
\hline Negative emotion & 2932 & 3.99 & 2.07 & 0.00 & 10.00 & $-.51^{* *}$ & $-.37^{* *}$ & $-.42^{* *}$ & $-.47^{* *}$ & $-.43^{* *}$ & $-.53^{* *}$ & & \\
\hline Physical health a & 2855 & 3.45 & 1.01 & 1.00 & 5.00 & $.36^{* *}$ & $.33^{* *}$ & $.34^{* *}$ & $.38^{* *}$ & $.41^{* *}$ & $.44^{* *}$ & $-.27^{* *}$ & \\
\hline Loneliness b & 2919 & 4.47 & 3.33 & 0.00 & 10.00 & $-.43^{* *}$ & $-.32^{* *}$ & $-.57^{* *}$ & $-.44^{* *}$ & $-.36^{* *}$ & $-.52^{* *}$ & $.41^{* *}$ & $-.24^{* *}$ \\
\hline Depression ${ }^{c}$ & 2824 & 15.70 & 5.82 & 8.00 & 32.00 & $-.66^{* *}$ & $-.56^{* *}$ & $-.65^{* *}$ & $-.67^{* *}$ & $-.60^{* *}$ & $-.76^{* *}$ & $605^{* *}$ & $-.42^{* *}$ \\
\hline Life satisfaction $\mathrm{d}$ & 2864 & 22.57 & 7.82 & 5.00 & 35.00 & $.66^{* *}$ & $.55^{* *}$ & $.67^{* *}$ & $.73^{* *}$ & $.66^{* *}$ & $.79^{* *}$ & $-.50^{* *}$ & $.43^{* *}$ \\
\hline Flourishing e & 2833 & 43.16 & 9.32 & 8.00 & 56.00 & $.69^{* *}$ & $.68^{* *}$ & $.69^{* *}$ & $.83^{* *}$ & $.73^{* *}$ & $.87^{* *}$ & $-.51^{* *}$ & $.42^{* *}$ \\
\hline WEMWBS f & 2820 & 24.79 & 5.21 & 7.00 & 35.00 & $.66^{* *}$ & $.62^{* *}$ & $.66^{* *}$ & $.73^{* *}$ & $.68^{* *}$ & $.81^{* *}$ & $-.57^{* *}$ & $.43^{* *}$ \\
\hline PAC-10 g & 2787 & 74.80 & 19.49 & 10.00 & 110.00 & $.63^{* *}$ & $.64^{* *}$ & $.63^{* *}$ & $.74^{* *}$ & $.65^{* *}$ & $.80^{* *}$ & $-.52^{* *}$ & $.41^{* *}$ \\
\hline \multicolumn{14}{|c|}{ Sample 3 (Mturk sample) } \\
\hline Positive emotion & 405 & 6.78 & 1.80 & 1.00 & 10.00 & & & & & & & & \\
\hline Engagement & 408 & 6.92 & 1.80 & 0.67 & 10.00 & $.52^{* *}$ & & & & & & & \\
\hline Relationships & 408 & 7.08 & 2.09 & 0.00 & 10.00 & $.64^{* *}$ & $.63^{* *}$ & & & & & & \\
\hline Meaning & 408 & 7.00 & 2.06 & 0.00 & 10.00 & $.65^{* *}$ & $.71^{* *}$ & $.75^{* *}$ & & & & & \\
\hline Accomplishment & 408 & 6.85 & 1.93 & 0.00 & 10.00 & $.62^{* *}$ & $.70^{* *}$ & $.72^{* *}$ & $.82^{* *}$ & & & & \\
\hline Overall wellbeing & 408 & 6.91 & 1.67 & 1.25 & 10.00 & $.79^{* *}$ & $.81^{* *}$ & $.88^{* *}$ & $.92^{* *}$ & $.90^{* *}$ & & & \\
\hline Negative emotion & 405 & 4.39 & 2.17 & 0.00 & 9.67 & $-.20^{* *}$ & $-.14^{* *}$ & $-.27^{* *}$ & $-.20^{* *}$ & $-.29^{* *}$ & $-.26^{* *}$ & & \\
\hline Physical health a & 403 & 3.40 & 0.86 & 1.00 & 5.00 & $.39^{* *}$ & $.30^{* *}$ & $.41^{* *}$ & $.37^{* *}$ & $.40^{* *}$ & $.44^{* *}$ & $-.17^{* *}$ & \\
\hline Loneliness $b$ & 405 & 5.29 & 3.02 & 0.00 & 10.00 & $-.12^{*}$ & -0.03 & $-.19^{* *}$ & $-.10^{*}$ & $-.16^{* *}$ & $-.15^{* *}$ & $.39^{* *}$ & -.09 \\
\hline Depression $^{c}$ & 381 & 16.82 & 5.26 & 8.00 & 32.00 & $-.49^{* *}$ & $-.36^{* *}$ & $-.56^{* *}$ & $-.51^{* *}$ & $-.58^{* *}$ & $-.59^{* *}$ & $.50^{* *}$ & $-.40^{* *}$ \\
\hline Life satisfaction $\mathrm{d}$ & 399 & 23.76 & 6.74 & 5.00 & 35.00 & $.61^{* *}$ & $.46^{* *}$ & $.72^{* *}$ & $.69^{* *}$ & $.68^{* *}$ & $.75^{* *}$ & $-.26^{* *}$ & $.50^{* *}$ \\
\hline Flourishing e & 387 & 42.33 & 8.31 & 17.00 & 56.00 & $.66^{* *}$ & $.69^{* *}$ & $.79^{* *}$ & $.81^{* *}$ & $.77^{* *}$ & $.87^{* *}$ & $-.32^{* *}$ & $.46^{* *}$ \\
\hline WEMWBS $\mathrm{f}$ & 379 & 25.70 & 4.85 & 10.00 & 35.00 & $.62^{* *}$ & $.54^{* *}$ & $.66^{* *}$ & $.68^{* *}$ & $.68^{* *}$ & $.75^{* *}$ & $-.30^{* *}$ & $.45^{* *}$ \\
\hline PAC-10 g & 395 & 75.15 & 17.72 & 26.00 & 110.00 & $.58^{* *}$ & $.50^{* *}$ & $.69^{* *}$ & $.71^{* *}$ & $.67^{* *}$ & $.75^{* *}$ & $-.34^{* *}$ & $.49^{* *}$ \\
\hline
\end{tabular}




\begin{tabular}{|c|c|c|c|c|c|c|c|c|c|c|c|c|c|}
\hline & $\mathbf{N}$ & Mean & SD & Min & Max & $\mathbf{P}$ & $\mathrm{E}$ & $\mathbf{R}$ & $\mathbf{M}$ & A & Overall & NE & $\mathbf{H}$ \\
\hline \multicolumn{14}{|c|}{ Sample 4 (Brief measure test set) } \\
\hline Positive emotion & 4717 & 6.43 & 1.97 & 0.00 & 10.00 & & & & & & & & \\
\hline Engagement & 4717 & 6.92 & 1.76 & 0.00 & 10.00 & $.66^{* *}$ & & & & & & & \\
\hline Relationships & 4717 & 6.63 & 2.20 & 0.00 & 10.00 & $.69^{* *}$ & $.48^{* *}$ & & & & & & \\
\hline Meaning & 4717 & 6.77 & 2.20 & 0.00 & 10.00 & $.78^{* *}$ & $.60^{* *}$ & $.61^{* *}$ & & & & & \\
\hline Accomplishment & 4717 & 6.78 & 1.80 & 0.00 & 10.00 & $.70^{* *}$ & $.56^{* *}$ & $.54^{* *}$ & $.78^{* *}$ & & & & \\
\hline Overall wellbeing & 4717 & 6.70 & 1.67 & 0.00 & 10.00 & $.91^{* *}$ & $.76^{* *}$ & $.80^{* *}$ & $.90^{* *}$ & $.84^{* *}$ & & & \\
\hline Negative emotion & 4717 & 4.19 & 2.00 & 0.00 & 10.00 & $-.58^{* *}$ & $-.33^{* *}$ & $-.46^{* *}$ & $-.46^{* *}$ & $-.44^{* *}$ & $-.55^{* *}$ & & \\
\hline Physical health $\mathrm{h}$ & 4715 & 7.02 & 2.09 & 0.00 & 10.00 & $.49^{* *}$ & $.34^{* *}$ & $.40^{* *}$ & $.44^{* *}$ & $.46^{* *}$ & $.51^{* *}$ & $-.32^{* *}$ & \\
\hline Loneliness & 4702 & 4.00 & 2.86 & 0.00 & 10.00 & $-.45^{* *}$ & $-.29^{* *}$ & $-.50^{* *}$ & $-.39^{* *}$ & $-.32^{* *}$ & $-.47^{* *}$ & $.50^{* *}$ & $-.22^{* *}$ \\
\hline \multicolumn{14}{|c|}{ Sample 5 (Main norming set) } \\
\hline Positive emotion & 23692 & 6.81 & 1.95 & 0.00 & 10.00 & & & & & & & & \\
\hline Engagement & 23692 & 7.38 & 1.67 & 0.00 & 10.00 & $.64^{* *}$ & & & & & & & \\
\hline Relationships & 23692 & 6.98 & 2.14 & 0.00 & 10.00 & $.68^{* *}$ & $.46^{* *}$ & & & & & & \\
\hline Meaning & 23692 & 7.16 & 2.16 & 0.00 & 10.00 & $.75^{* *}$ & $.60^{* *}$ & $.60^{* *}$ & & & & & \\
\hline Accomplishment & 23692 & 7.39 & 1.74 & 0.00 & 10.00 & $.68^{* *}$ & $.57^{* *}$ & $.54^{* *}$ & $.79^{* *}$ & & & & \\
\hline Overall wellbeing & 23692 & 7.14 & 1.64 & 0.00 & 10.00 & $.90^{* *}$ & $.76^{* *}$ & $.80^{* *}$ & $.89^{* *}$ & $.84^{* *}$ & & & \\
\hline Negative emotion & 23692 & 4.51 & 2.08 & 0.00 & 10.00 & $-.51^{* *}$ & $-.27^{* *}$ & $-.39^{* *}$ & $-.41^{* *}$ & $-.36^{* *}$ & $-.47^{* *}$ & & \\
\hline Physical health $\mathrm{h}$ & 23692 & 6.96 & 2.20 & 0.00 & 10.00 & $.48^{* *}$ & $.32^{* *}$ & $.40^{* *}$ & $.43^{* *}$ & $.46^{* *}$ & $.50^{* *}$ & $-.31^{* *}$ & \\
\hline Loneliness ${ }^{\mathrm{b}}$ & 23692 & 4.13 & 3.04 & 0.00 & 10.00 & $-.44^{* *}$ & $-.24^{* *}$ & $-.50^{* *}$ & $-.38^{* *}$ & $-.32^{* *}$ & $-.46^{* *}$ & $.55^{* *}$ & $-.24^{* *}$ \\
\hline \multicolumn{14}{|c|}{ Sample 6 (Compassion study) } \\
\hline Positive emotion & 285 & 7.12 & 1.48 & 1.33 & 10.00 & & & & & & & & \\
\hline Engagement & 282 & 7.64 & 1.45 & 2.33 & 10.00 & $.53^{* *}$ & & & & & & & \\
\hline Relationships & 285 & 7.53 & 1.77 & 1.33 & 10.00 & $.65^{* *}$ & $.33^{* *}$ & & & & & & \\
\hline Meaning & 279 & 7.93 & 1.76 & 1.00 & 10.00 & $.60^{* *}$ & $.50^{* *}$ & $.56^{* *}$ & & & & & \\
\hline Accomplishment & 282 & 7.35 & 1.47 & 1.67 & 10.00 & $.56^{* *}$ & $.48^{* *}$ & $.43^{* *}$ & $.57^{* *}$ & & & & \\
\hline Overall wellbeing & 285 & 7.50 & 1.27 & 1.81 & 9.81 & $.85^{* *}$ & $.70^{* *}$ & $.79^{* *}$ & $.84^{* *}$ & $.75^{* *}$ & & & \\
\hline Political orientation ${ }^{\mathrm{i}}$ & 245 & 2.31 & 1.49 & 1.00 & 7.00 & -.09 & $-.15^{*}$ & -.12 & $-.16^{*}$ & .07 & -.12 & & \\
\hline Identifies as an activist $j$ & 285 & 36.96 & 13.39 & 8.00 & 56.00 & .009 & $.18^{* *}$ & -.04 & $.20^{* *}$ & .01 & .07 & & \\
\hline Life satisfaction $\mathrm{d}$ & 285 & 24.21 & 6.54 & 5.00 & 35.00 & $.63^{* *}$ & $.36^{* *}$ & $.60^{* *}$ & $.50^{* *}$ & $.50^{* *}$ & $.67^{* *}$ & & \\
\hline Self-compassion ${ }^{k}$ & 277 & 3.13 & 0.62 & 1.42 & 4.58 & $.49^{* *}$ & $.29^{* *}$ & $.45^{* *}$ & $.45^{* *}$ & $.35^{* *}$ & $.52^{* *}$ & & \\
\hline
\end{tabular}




\begin{tabular}{|c|c|c|c|c|c|c|c|c|c|c|c|c|c|}
\hline & $\mathbf{N}$ & Mean & SD & Min & Max & $\mathbf{P}$ & $E$ & $\mathbf{R}$ & $\mathbf{M}$ & A & Overall & NE & $\mathbf{H}$ \\
\hline Hope $^{1}$ & 265 & 51.41 & 7.84 & 11.00 & 64.00 & $.58^{* *}$ & $.55^{* *}$ & $.41^{* *}$ & $.64^{* *}$ & $.65^{* *}$ & $.72^{* *}$ & & \\
\hline Compassion ${ }^{m}$ & 264 & 5.67 & 1.00 & 2.60 & 7.00 & $.13^{*}$ & $.25^{* *}$ & .02 & $.19^{* *}$ & $.15^{*}$ & $.17^{* *}$ & & \\
\hline Activist orientation ${ }^{n}$ & 256 & 2.13 & 0.86 & 1.00 & 4.50 & $-.16^{*}$ & .004 & -.12 & -.07 & $-.20^{* *}$ & $-.14^{*}$ & & \\
\hline Burnout ${ }^{\circ}$ & 195 & 2.15 & 0.42 & 1.00 & 3.56 & $-.42^{* *}$ & $-.43^{* *}$ & $-.34^{* *}$ & $-.46^{* *}$ & $-.57^{* *}$ & $-.56^{* *}$ & & \\
\hline Self-determination $\mathrm{p}$ & 250 & 2.20 & 0.66 & 1.00 & 4.40 & $-.53^{* *}$ & $-.35^{* *}$ & $-.47^{* *}$ & $-.54^{* *}$ & $-.46^{* *}$ & $-.60^{* *}$ & & \\
\hline
\end{tabular}

Sample 7 (Online organization employees)

Positive emotion

Engagement

Relationships

Meaning

Accomplishment

Overall wellbeing

Work performance $q$

Organization practices ${ }^{r}$

Social capital $s$

Sample 8 (Values study)

Positive emotion

Engagement

Relationships

Meaning

Accomplishment

Overall wellbeing

Negative emotion

Physical health $\mathrm{h}$

Loneliness ${ }^{b}$

Values $\mathrm{t}$

Sample 9 (Harvard University students)

Positive emotion

Engagement

Relationships

Meaning

$\begin{array}{lllll}294 & 7.26 & 1.52 & 1.67 & 10.00\end{array}$

$\begin{array}{lllll}294 & 7.26 & 1.52 & 1.67 & 10.00 \\ 294 & 7.84 & 1.26 & 3.33 & 10.00\end{array}$

$\begin{array}{llllll}289 & 7.75 & 1.61 & 1.00 & 10.00 & .66^{* *}\end{array}$

$\begin{array}{llllll}288 & 7.63 & 1.64 & 0.00 & 10.00 & .63^{* *}\end{array}$

$294 \quad 7.41 \quad 1.36 \quad 3.00$

$\begin{array}{llll}294 & 7.59 & 1.18 & 3.31\end{array}$

$\begin{array}{llll}293 & 8.09 & 1.13 & 3.00\end{array}$

$\begin{array}{llll}294 & 7.99 & 1.34 & 2.25\end{array}$

$293 \quad 7.63 \quad 1.50 \quad 3.25$

10.00

10.00

10.00

$10.00 \quad 33^{*}$

$10.00 \quad 37^{* *}$

$\begin{array}{lllll}166 & 6.27 & 1.80 & 1.00 & 9.67\end{array}$

$\begin{array}{lllll}166 & 6.95 & 1.69 & 1.67 & 10.00\end{array}$

$\begin{array}{llll}166 & 6.85 & 2.02 & 0.67\end{array}$

$\begin{array}{llll}166 & 6.51 & 2.24 & 0.33\end{array}$

$\begin{array}{llll}166 & 6.82 & 1.65 & 1.33\end{array}$

$\begin{array}{llll}166 & 6.67 & 1.54 & 1.50\end{array}$

$\begin{array}{llll}166 & 4.41 & 1.84 & 0.33\end{array}$

$\begin{array}{llll}166 & 6.57 & 2.07 & 0.00\end{array}$

$\begin{array}{llll}166 & 4.05 & 2.85 & 0.00\end{array}$

$\begin{array}{llll}163 & 77.14 & 15.26 & 2.00\end{array}$

2.00

$\begin{array}{llllll}184 & 6.67 & 1.73 & 2.00 & 10.00 & \\ 184 & 7.25 & 1.60 & 1.33 & 10.00 & .54^{* *} \\ 184 & 7.11 & 2.06 & 1.00 & 10.00 & .55^{* *}\end{array}$

$\begin{array}{llll}184 & 7.12 & 1.70 & 1.67\end{array}$

$10.00 \quad 70^{* *}$

$.22^{* *}$

$49^{* *}$ 


\begin{tabular}{|c|c|c|c|c|c|c|c|c|c|c|c|c|c|}
\hline & $\mathbf{N}$ & Mean & SD & Min & Max & $\mathbf{P}$ & $\mathrm{E}$ & $\mathbf{R}$ & $\mathbf{M}$ & A & Overall & NE & $\mathbf{H}$ \\
\hline Accomplishment & 184 & 7.01 & 1.52 & 2.00 & 10.00 & $.62^{* *}$ & $.39^{* *}$ & $.45^{* *}$ & $.71^{* *}$ & & & & \\
\hline Overall wellbeing & 184 & 7.03 & 1.34 & 3.07 & 9.73 & $.87^{* *}$ & $.66^{* *}$ & $.72^{* *}$ & $.86^{* *}$ & $.79^{* *}$ & & & \\
\hline Negative emotion & 184 & 4.33 & 1.86 & 0.33 & 9.00 & $-.48^{* *}$ & $-.17^{*}$ & $-.20^{* *}$ & $-.35^{* *}$ & $-.33^{* *}$ & $-.39^{* *}$ & & \\
\hline Physical health $\mathrm{h}$ & 184 & 7.09 & 2.06 & 0.33 & 10.00 & $.54^{* *}$ & $.38^{* *}$ & $.26^{* *}$ & $.47^{* *}$ & $.45^{* *}$ & $.53^{* *}$ & $-.26^{* *}$ & \\
\hline Loneliness ${ }^{b}$ & 184 & 4.77 & 2.84 & 0.00 & 10.00 & $-.44^{* *}$ & $-.21^{* *}$ & $-.45^{* *}$ & $-.36^{* *}$ & $-.25^{* *}$ & $-.45^{* *}$ & $.45^{* *}$ & $-.18^{* *}$ \\
\hline Hope u & 182 & 5.46 & 0.96 & 2.60 & 7.00 & $.64^{* *}$ & $.48^{* *}$ & $.44^{* *}$ & $.67^{* *}$ & $.69^{* *}$ & $.74^{* *}$ & $-.46^{* *}$ & $.41^{* *}$ \\
\hline Self-efficacy ${ }^{v}$ & 181 & 5.76 & 0.88 & 2.50 & 7.00 & $.53^{* *}$ & $.37^{* *}$ & $.33^{* *}$ & $.53^{* *}$ & $.60^{* *}$ & $.59^{* *}$ & $-.43^{* *}$ & $.39^{* *}$ \\
\hline Gratitude w & 181 & 6.16 & 0.84 & 3.00 & 7.00 & $.39^{* *}$ & .09 & $.55^{* *}$ & $.22^{* *}$ & $.24^{* *}$ & $.40^{* *}$ & $-.30^{* *}$ & $.16^{*}$ \\
\hline Perceived stress ${ }^{x}$ & 179 & 3.23 & 1.23 & 1.17 & 7.00 & $-.45^{* *}$ & $-.20^{* *}$ & $-.35^{* *}$ & $-.39^{* *}$ & $-.43^{* *}$ & $-.47^{* *}$ & $.58^{* *}$ & $-.30^{* *}$ \\
\hline Depression y & 184 & 2.68 & 1.96 & 1.00 & 9.50 & $-.35^{* *}$ & -.12 & $-.38^{* *}$ & $-.37^{* *}$ & $-.31^{* *}$ & $-.40^{* *}$ & $.57^{* *}$ & $-.18^{*}$ \\
\hline Anxiety y & 184 & 2.84 & 1.34 & 1.00 & 6.50 & $-.44^{* *}$ & $-.21^{* *}$ & $-.30^{* *}$ & $-.38^{* *}$ & $-.39^{* *}$ & $-.44^{* *}$ & $.66^{* *}$ & $-.25^{* *}$ \\
\hline Fatigue y & 181 & 3.35 & 1.40 & 1.00 & 7.00 & $-.45^{* *}$ & $-.26^{* *}$ & $-.27^{* *}$ & $-.40^{* *}$ & $-.38^{* *}$ & $-.45^{* *}$ & $.53^{* *}$ & $-.58^{* *}$ \\
\hline Life satisfaction $\mathrm{z}$ & 176 & 6.65 & 1.84 & 1.00 & 10.00 & $.68^{* *}$ & $.45^{* *}$ & $.55^{* *}$ & $.65^{* *}$ & $.70^{* *}$ & $.77^{* *}$ & $-.43^{* *}$ & $.39^{* *}$ \\
\hline
\end{tabular}

\section{Sample 10 (Positive intervention study)}

Positive emotion

Engagement

Relationships

Meaning

Accomplishment

Overall wellbeing

Negative emotion

Physical health $\mathrm{h}$

Loneliness ${ }^{b}$

Hope $\mathrm{u}$

Self-efficacy $v$

Gratitude w

Perceived stress $x$

Depression y

Anxiety y

Fatigue y

Life satisfaction ${ }^{z}$

$\begin{array}{lllll}1846 & 5.83 & 2.08 & 0.00 & 10.00\end{array}$

$\begin{array}{lllll}1846 & 6.63 & 1.87 & 0.00 & 10.00\end{array}$

1825

1825

1846

1846

1845

1844

1825

1778

1724

1738

1701

1790

1800

1738

1637
6.39

6.34

6.24

6.28
4.84

4.84
6.55

6.55
4.94

4.83

5.29

5.70

3.64

3.40

3.17

3.64
5.78

5.78

2.23

2.28

1.90

1.75

1.96

2.16

2.92

1.27

1.14

1.08

1.38

2.21

1.37

1.45

2.25
0.00

0.00

0.33

0.20

0.67

0.00

0.00

1.00

1.00

1.00

1.00

1.00

1.00

1.00

0.00
10.00

10.00

10.00

10.00

10.00

10.00

10.00

10.00

7.00

$$
7.00
$$$$
7.00
$$

7.00

10.00

7.00

7.00

10.00
$.67^{* *}$

$.69^{* *} \quad .46^{* *}$

$.77^{* *}$

$.68^{* *}$

$91^{* *}$

$-.56^{* *}$

$.45^{* *}$

$-.46^{* *}$

$.67^{* *}$

$.60^{* *}$

$.60^{* *}$

$-.59^{* *}$

$-.64^{* *}$

$-.64$

$-.42^{* *}$

$.79^{* *}$

$.64^{* *}$

$59^{* *}$

$-.28^{* *}$

$.57^{* *}$

$.52^{* *}$

$.45^{* *}$

$-.36^{* *}$

$-.41^{* *}$
$-.35^{* *}$

$-.30^{* *}$
$.79^{* *} \quad .79^{* *}$

$-.31^{* *} \quad-.40^{* *}$

$.29^{* *} \quad .34^{* *}$

$.54^{* *}$

$.67^{* *}$

$.73^{* *}$

$.90^{* *} \quad .83^{* *}$

$-.43^{* *} \quad-.38^{* *}$

$.40^{* *} \quad .43^{* *}$

$-.37^{* *} \quad-.31^{* *}$

$.69^{* *} \quad .70^{* *}$

$.61^{* *} \quad .65^{* *}$

$.55^{* *} \quad .47^{* *}$

$-.47^{* *} \quad-.49^{* *}$

$-.57^{* *} \quad-.51^{* *}$

$-.43^{* *} \quad-.45^{* *}$

$-.31^{* *} \quad-.37^{* *}$

$.71^{* *}$

$.66^{* *}$

$-.50$

$.45^{* *} \quad-.31^{* *}$

$-.45^{* *} \quad .50^{* *} \quad-.19^{* *}$

$.73^{* *} \quad-.45^{* *} \quad .36^{* *}$

$66^{* *}-.44^{* *} \quad 36^{* *}$

$.62^{* *} \quad-.46^{* *} \quad .30^{* *}$

$-.56^{* *} \quad .68^{* *} \quad-.37^{* *}$

$-.63^{* *} \quad .59^{* *} \quad-.33^{* *}$

$\begin{array}{lll}-.51^{* *} & .68^{* *} & -.29^{* *}\end{array}$

$-.40^{* *} \quad .46^{* *} \quad-.46^{* *}$

$.80^{* *} \quad-.54^{* *} \quad .44^{* *}$ 


\begin{tabular}{|c|c|c|c|c|c|c|c|c|c|c|c|c|c|}
\hline & $\mathbf{N}$ & Mean & SD & Min & Max & $\mathbf{P}$ & E & $\mathbf{R}$ & $\mathbf{M}$ & A & Overall & NE & $\mathbf{H}$ \\
\hline \multicolumn{14}{|c|}{ Sample 11 (William $\mathcal{E}$ Mary University sample) } \\
\hline Positive emotion & 781 & 6.30 & 1.63 & 0.00 & 10.00 & & & & & & & & \\
\hline Engagement & 781 & 6.55 & 1.43 & 1.67 & 10.00 & $.56^{* *}$ & & & & & & & \\
\hline Relationships & 782 & 6.74 & 1.85 & 0.33 & 10.00 & $.65^{* *}$ & $.48^{* *}$ & & & & & & \\
\hline Meaning & 780 & 6.77 & 2.00 & 0.00 & 10.00 & $.73^{* *}$ & $.58^{* *}$ & $.61^{* *}$ & & & & & \\
\hline Accomplishment & 782 & 6.80 & 1.56 & 0.00 & 10.00 & $.63^{* *}$ & $.49^{* *}$ & $.56^{* *}$ & $.71^{* *}$ & & & & \\
\hline Overall wellbeing & 782 & 6.64 & 1.41 & 1.06 & 9.63 & $.87^{* *}$ & $.72^{* *}$ & $.81^{* *}$ & $.89^{* *}$ & $.82^{* *}$ & & & \\
\hline Negative emotion & 782 & 4.02 & 1.68 & 0.00 & 9.00 & $-.63^{* *}$ & $-.34^{* *}$ & $-.42^{* *}$ & $-.53^{* *}$ & $-.48^{* *}$ & $-.59^{* *}$ & & \\
\hline Loneliness ${ }^{\mathrm{b}}$ & 762 & 4.18 & 2.42 & 0.00 & 10.00 & $-.52^{* *}$ & $-.34^{* *}$ & $-.58^{* *}$ & $-.46^{* *}$ & $-.37^{* *}$ & $-.57^{* *}$ & $.54^{* *}$ & \\
\hline
\end{tabular}

a Four physical health items adapted from the Short-Form 36 (Ware \& Sherbourne) physical function subscale; b single item ("How lonely do you feel in your daily life?"); c Center of Epidemiological Studies-Depression Scale (CES-D, Radloff, 1977); d Satisfaction with Life Scale (SWLS, Diener, Emmons, Larsen, \& Griffin, 1985); e Flourishing Scale (Diener et

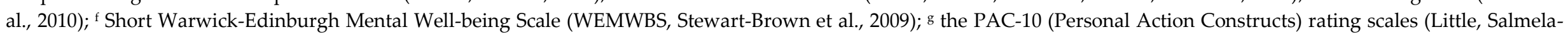
Aro, \& Phillips, 2007); ${ }^{\mathrm{h}}$ final three health items included in the 23-item PERMA-Profiler measure; ${ }^{\mathrm{i}}$ single item on political orientation $\left(1=\right.$ liberal, $7=$ conservative); ${ }^{j}$ Activist Identity Scale (Klar \& Klassar, 2009); k Self-Compassion Scale (Neff, 2003); 1 12-item Adult Hope Scale (Snyder, Irving, \& Anderson, 1991); m Santa Clara Brief Compassion Scale (Hwang, Plante, \& Lackey, 2008); ${ }^{n}$ Activist Orientation Scale (Corning \& Myers, 2002); ${ }^{\circ}$ Maslach Burnout Inventory (Maslach, Jackson, \& Leiter, 1997); p Self-determination Scale (Sheldon \& Deci, 1996); q single item self-rating on overall work performance $\left(0=\right.$ low, $10=$ high); ${ }^{\mathrm{r}}$ organizational practices subscale from the Organizational Virtuousness Scale (Cameron, Bright, \& Caza, 2004); s four self-rated items ( 0 = strongly disagree, 10 = strongly agree: I feel a sense of belonging at work; I socialize with my co-workers outside of work; I can trust and depend on my co-workers; I have positive feelings towards my co-workers); ${ }^{\text {t }}$ average self-ratings across 13 values (work, time balance, education, achievement, material wealth, health, good time, helping others, security, nature, family, spirituality, other) adapted from Schwartz (2012); " 8 -item Hope Scale (Snyder, 1995); v General Self-efficacy Scale (Chen, Gully, \& Eden, 2001); w Gratitude Questionnaire (McCullough, Emmons, \& Tsang, 2002); x Perceived Stress Scale (Cohen, Kamarck, \& Mermelstein, 1983); y PROMIS short-form scales (Pilkonis et al., 2011); ${ }^{z}$ average of two self-ratings on overall life satisfaction (Cantril's Ladder and "Overall, how satisfied are you with your life nowadays?"). 


\section{Appendix 2 References}

Cameron, K., Bright., D., \& Caza, A. (2004). Exploring the relationships between organizational virtuousness and performance. American Behavioral Scientist, 47(6), 766-790. http://dx.doi.org/10.1177/0002764203260209

Cantril, H. (1965). The pattern of human concerns. New Brunswick, NJ: Rutgers University Press.

Chen, G., Gully, S. M., \& Eden, D. (2001).Validation of a new General Self-Efficacy Scale. Organizational Research Methods, 4(1), 62-83. http://dx.doi.org/10.1177/109442810141004

Cohen, S., Kamarck, T., Mermelstein, R. (1983). A global measure of perceived stress. Journal of Health and Social Behavior, 24(4), 385-396. http://dx.doi.org/10.2307/2136404

Corning, A., \& Myers, D. (2002). Individual orientation towards engagement in social action. Political Psychology, 23(4), 702-739. http://dx.doi.org/10.1111/0162-895X.00304

Diener, E., Emmons, R. A., Larsen, R. J., \& Griffin, S. (1985). The satisfaction with life scale. Journal of Personality Assessment, 49(1), 71-75. http://dx.doi.org/10.1207/s15327752jpa4901 13

Diener, E., Wirtz, D., Tov, W., Kim-Prieto, C., Choi, D., Oishi, S., \& Biswas-Diener, R. (2010). New wellbeing measures: Short scales to assess flourishing and positive and negative feelings. Social Indicators Research, 97(2), 143-156. http://dx.doi.org/10.1007/s11205-009-9493-y

Hwang, J. Y., Plante, T., \& Lackey, K. (2008). The development of the Santa Clara Brief Compassion Scale: An abbreviation of Sprecher and Fehr's Compassionate Love Scale. Pastoral Psychology, 56(4), 421428. http://dx.doi.org/10.1007/s11089-008-0117-2

Klar, M., \& Kasser, T. (2009). Some benefits of being an activist: Measuring activism and its role in psychological well-being. Political Psychology, 30(5), 755-777. http://dx.doi.org/10.1111/j.14679221.2009.00724.x

Little, B., Salmela-Aro, K., \& Phillips, S. (2007). Personal project pursuit: Goals, action and human flourishing. Hillsdale, NJ: Lawrence Erlbaum Associates.

Maslach, C., Jackson, S. E., \& Leiter, M. P. (1997). Maslach Burnout Inventory. (3rd ed.). In C. P. Zalaquett \& R. J. Wood (Eds.), Evaluating stress: A book of resources (pp. 191-218). Lanham, MD: Scarecrow Education.

McCullough, M. E., Emmons, R. A., \& Tsang, J. (2002). The grateful disposition: A conceptual and empirical topography. Journal of Personality and Social Psychology, 82, 112-127. http://dx.doi.org/10.1037/0022-3514.82.1.112

Neff, K. (2003). The development and validation of a scale to measure self-compassion. Self and Identity, 2(3), 223-250. http://dx.doi.org/10.1080/15298860309027

Pilkonis, P. A., Choi, S. W., Reise, S. P., Stover, A. M., Riley, W. T., \& Cella, D. (2011). Item banks for measuring emotional distress from the Patient-Reported Outcomes Measurement Information System (PROMISTM): Depression, anxiety, and anger. Assessment, 18(3), 263-283. http://dx.doi.org/10.1177/1073191111411667

Radloff, L. S. (1977). The CES-D scale: A self-report depression scale for research in the general population. Applied Psychological Measurement, 1(3), 385-401. http://dx.doi.org/10.1177/014662167700100306

Schwartz, S. H. (2012). An overview of the Schwartz theory of basic values. Online Readings in Psychology and Culture, 2. http://dx.doi.org/10.9707/2307-0919.1116

Sheldon, K., \& Deci, E. (1996). The self-determination scale. (Unpublished manuscript). University of Rochester, Rochester, NY.

Snyder, C. R. (1995) Conceptualizing, measuring, and nurturing hope. Journal of Counseling and Development, 73(3), 355-360. http://dx.doi.org/10.1002/j.1556-6676.1995.tb01764.x

Snyder, C. R., Irving, L. M., \& Anderson, J. R. (1991). In C. R. Snyder \& D. R. Forsyth (Eds.), Hope and health. Elmsford, NY: Pergamon Press.

Stewart-Brown, S., Tennant, A., Tennant, R., Platt, S., Parkinson, J., \& Weich, S. (2009). Internal construct validity of the Warwick-Edinburgh Mental Well-being Scale (WEMWBS): A Rasch analysis using data from the Scottish Health Education Population Survey. Health and Quality of Life Outcomes, 7(15), 1-8. http://dx.doi.org/10.1186/1477-7525-7-15 
Ware, J. E., \& Sherbourne, C. D. (1992). The MOS 36-item short-form health survey (SF-36): I. Conceptual framework and item selection. Medical Care, 30(6), 473-483. http://dx.doi.org/10.1097/00005650$\underline{199206000-00002}$ 
Appendix 3. PERMA-profiler norms

\begin{tabular}{|c|c|c|c|c|c|c|c|c|c|}
\hline & $\mathbf{N}$ & Mean & Median & SD & Min & 25th & 50th & 75th & Max \\
\hline \multicolumn{10}{|l|}{ Full Sample } \\
\hline Positive emotion & 31965 & 6.69 & 7.00 & 1.97 & 0.00 & 5.67 & 7.00 & 8.00 & 10.00 \\
\hline Engagement & 31962 & 7.25 & 7.67 & 1.71 & 0.00 & 6.33 & 7.67 & 8.33 & 10.00 \\
\hline Relationships & 31940 & 6.90 & 7.33 & 2.15 & 0.00 & 5.67 & 7.33 & 8.67 & 10.00 \\
\hline Meaning & 31931 & 7.06 & 7.67 & 2.17 & 0.00 & 6.00 & 7.67 & 8.67 & 10.00 \\
\hline Accomplishment & 31963 & 7.21 & 7.67 & 1.78 & 0.00 & 6.33 & 7.67 & 8.33 & 10.00 \\
\hline Overall wellbeing & 31966 & 7.02 & 7.38 & 1.66 & 0.00 & 6.13 & 7.38 & 8.25 & 10.00 \\
\hline Negative emotion & 31386 & 4.46 & 4.33 & 2.06 & 0.00 & 3.00 & 4.33 & 6.00 & 10.00 \\
\hline Physical health & 30601 & 6.94 & 7.33 & 2.18 & 0.00 & 5.67 & 7.33 & 8.67 & 10.00 \\
\hline \multicolumn{10}{|l|}{ Gender: Male } \\
\hline Positive emotion & 17752 & 6.79 & 7.33 & 1.92 & 0.00 & 5.67 & 7.33 & 8.33 & 10.00 \\
\hline Engagement & 17752 & 7.32 & 7.67 & 1.67 & 0.00 & 6.33 & 7.67 & 8.67 & 10.00 \\
\hline Relationships & 17751 & 7.00 & 7.33 & 2.12 & 0.00 & 5.67 & 7.33 & 8.67 & 10.00 \\
\hline Meaning & 17746 & 7.13 & 7.67 & 2.12 & 0.00 & 6.00 & 7.67 & 8.67 & 10.00 \\
\hline Accomplishment & 17752 & 7.35 & 7.67 & 1.72 & 0.00 & 6.33 & 7.67 & 8.67 & 10.00 \\
\hline Overall wellbeing & 17753 & 7.11 & 7.50 & 1.61 & 0.00 & 6.25 & 7.50 & 8.31 & 10.00 \\
\hline Negative emotion & 17517 & 4.55 & 4.67 & 2.05 & 0.00 & 3.00 & 4.67 & 6.00 & 10.00 \\
\hline Physical health & 17229 & 6.89 & 7.33 & 2.21 & 0.00 & 5.67 & 7.33 & 8.67 & 10.00 \\
\hline \multicolumn{10}{|l|}{ Gender: Female } \\
\hline Positive emotion & 13653 & 6.57 & 7.00 & 2.01 & 0.00 & 5.33 & 7.00 & 8.00 & 10.00 \\
\hline Engagement & 13650 & 7.17 & 7.33 & 1.73 & 0.00 & 6.33 & 7.33 & 8.33 & 10.00 \\
\hline Relationships & 13650 & 6.78 & 7.33 & 2.17 & 0.00 & 5.33 & 7.33 & 8.33 & 10.00 \\
\hline Meaning & 13646 & 6.98 & 7.67 & 2.23 & 0.00 & 5.67 & 7.67 & 8.67 & 10.00 \\
\hline Accomplishment & 13651 & 7.08 & 7.33 & 1.82 & 0.00 & 6.00 & 7.33 & 8.33 & 10.00 \\
\hline Overall wellbeing & 13653 & 6.91 & 7.27 & 1.69 & 0.00 & 5.94 & 7.27 & 8.13 & 10.00 \\
\hline Negative emotion & 13314 & 4.34 & 4.33 & 2.05 & 0.00 & 2.67 & 4.33 & 6.00 & 10.00 \\
\hline Physical health & 12821 & 7.03 & 7.67 & 2.14 & 0.00 & 5.67 & 7.67 & 8.67 & 10.00 \\
\hline \multicolumn{10}{|l|}{ Gender: Unknown } \\
\hline Positive emotion & 557 & 6.21 & 6.33 & 2.02 & 0.00 & 5.00 & 6.33 & 8.00 & 10.00 \\
\hline Engagement & 557 & 6.76 & 7.00 & 1.86 & 1.50 & 5.50 & 7.00 & 8.00 & 10.00 \\
\hline Relationships & 536 & 6.48 & 7.00 & 2.24 & 0.00 & 5.00 & 7.00 & 8.25 & 10.00 \\
\hline Meaning & 536 & 6.48 & 7.00 & 2.18 & 0.00 & 5.00 & 7.00 & 8.00 & 10.00 \\
\hline Accomplishment & 557 & 6.35 & 6.50 & 1.94 & 0.00 & 5.00 & 6.50 & 8.00 & 10.00 \\
\hline Overall wellbeing & 557 & 6.45 & 6.60 & 1.74 & 1.25 & 5.25 & 6.60 & 7.81 & 10.00 \\
\hline Negative emotion & 555 & 4.90 & 5.00 & 2.13 & 0.00 & 3.33 & 5.00 & 6.50 & 10.00 \\
\hline Physical health & 551 & 6.72 & 7.00 & 2.15 & 0.00 & 5.33 & 7.00 & 8.33 & 10.00 \\
\hline \multicolumn{10}{|l|}{ Age: Under 18} \\
\hline Positive emotion & 1500 & 6.85 & 7.33 & 1.83 & 0.00 & 5.67 & 7.33 & 8.33 & 10.00 \\
\hline Engagement & 1500 & 7.54 & 7.67 & 1.49 & 0.00 & 6.67 & 7.67 & 8.67 & 10.00 \\
\hline Relationships & 1500 & 6.84 & 7.33 & 2.02 & 0.00 & 5.67 & 7.33 & 8.33 & 10.00 \\
\hline Meaning & 1500 & 6.79 & 7.33 & 2.07 & 0.00 & 5.67 & 7.33 & 8.33 & 10.00 \\
\hline Accomplishment & 1500 & 7.02 & 7.33 & 1.77 & 0.00 & 6.00 & 7.33 & 8.33 & 10.00 \\
\hline Overall wellbeing & 1500 & 7.01 & 7.31 & 1.53 & 0.00 & 6.08 & 7.31 & 8.13 & 10.00 \\
\hline Negative emotion & 1500 & 4.98 & 5.00 & 2.08 & 0.00 & 3.33 & 5.00 & 6.67 & 10.00 \\
\hline Physical health & 1500 & 6.95 & 7.33 & 2.21 & 0.00 & 5.67 & 7.33 & 8.67 & 10.00 \\
\hline \multicolumn{10}{|l|}{ Age: 18-24 } \\
\hline Positive emotion & 8875 & 6.85 & 7.00 & 1.77 & 0.00 & 6.00 & 7.00 & 8.00 & 10.00 \\
\hline Engagement & 8875 & 7.33 & 7.67 & 1.52 & 0.00 & 6.67 & 7.67 & 8.33 & 10.00 \\
\hline Relationships & 8876 & 7.05 & 7.33 & 2.00 & 0.00 & 6.00 & 7.33 & 8.67 & 10.00 \\
\hline
\end{tabular}




\begin{tabular}{|c|c|c|c|c|c|c|c|c|c|}
\hline & $\mathbf{N}$ & Mean & Median & SD & Min & 25th & 50th & 75th & Max \\
\hline Meaning & 8874 & 7.11 & 7.67 & 1.98 & 0.00 & 6.00 & 7.67 & 8.67 & 10.00 \\
\hline Accomplishment & 8876 & 7.26 & 7.67 & 1.67 & 0.00 & 6.33 & 7.67 & 8.33 & 10.00 \\
\hline Overall wellbeing & 8876 & 7.12 & 7.38 & 1.48 & 0.00 & 6.31 & 7.38 & 8.19 & 10.00 \\
\hline Negative emotion & 8799 & 4.66 & 4.67 & 1.97 & 0.00 & 3.33 & 4.67 & 6.00 & 10.00 \\
\hline Physical health & 8018 & 6.88 & 7.33 & 2.09 & 0.00 & 5.67 & 7.33 & 8.33 & 10.00 \\
\hline \multicolumn{10}{|l|}{ Age 25-34 } \\
\hline Positive emotion & 6530 & 6.58 & 7.00 & 1.95 & 0.00 & 5.33 & 7.00 & 8.00 & 10.00 \\
\hline Engagement & 6528 & 7.11 & 7.33 & 1.75 & 0.00 & 6.00 & 7.33 & 8.33 & 10.00 \\
\hline Relationships & 6526 & 6.97 & 7.33 & 2.09 & 0.00 & 5.67 & 7.33 & 8.67 & 10.00 \\
\hline Meaning & 6521 & 6.95 & 7.33 & 2.21 & 0.00 & 5.67 & 7.33 & 8.67 & 10.00 \\
\hline Accomplishment & 6528 & 7.13 & 7.67 & 1.82 & 0.00 & 6.33 & 7.67 & 8.33 & 10.00 \\
\hline Overall wellbeing & 6530 & 6.94 & 7.31 & 1.66 & 0.13 & 6.00 & 7.31 & 8.13 & 10.00 \\
\hline Negative emotion & 6223 & 4.60 & 4.67 & 2.03 & 0.00 & 3.00 & 4.67 & 6.00 & 10.00 \\
\hline Physical health & 6223 & 6.80 & 7.33 & 2.19 & 0.00 & 5.33 & 7.33 & 8.33 & 10.00 \\
\hline \multicolumn{10}{|l|}{ Age 35-44 } \\
\hline Positive emotion & 5424 & 6.54 & 7.00 & 2.06 & 0.00 & 5.33 & 7.00 & 8.00 & 10.00 \\
\hline Engagement & 5424 & 7.14 & 7.67 & 1.79 & 0.00 & 6.33 & 7.67 & 8.33 & 10.00 \\
\hline Relationships & 5424 & 6.75 & 7.33 & 2.26 & 0.00 & 5.33 & 7.33 & 8.33 & 10.00 \\
\hline Meaning & 5423 & 6.96 & 7.67 & 2.27 & 0.00 & 5.67 & 7.67 & 8.67 & 10.00 \\
\hline Accomplishment & 5424 & 7.15 & 7.67 & 1.83 & 0.00 & 6.33 & 7.67 & 8.33 & 10.00 \\
\hline Overall wellbeing & 5424 & 6.90 & 7.27 & 1.74 & 0.00 & 5.88 & 7.27 & 8.19 & 10.00 \\
\hline Negative emotion & 5363 & 4.43 & 4.33 & 2.06 & 0.00 & 2.67 & 4.33 & 6.00 & 10.00 \\
\hline Physical health & 5363 & 6.88 & 7.33 & 2.22 & 0.00 & 5.67 & 7.33 & 8.67 & 10.00 \\
\hline \multicolumn{10}{|l|}{ Age 45-54 } \\
\hline Positive emotion & 4724 & 6.63 & 7.33 & 2.14 & 0.00 & 5.33 & 7.33 & 8.33 & 10.00 \\
\hline Engagement & 4724 & 7.22 & 7.67 & 1.84 & 0.00 & 6.33 & 7.67 & 8.67 & 10.00 \\
\hline Relationships & 4723 & 6.78 & 7.33 & 2.28 & 0.00 & 5.33 & 7.33 & 8.67 & 10.00 \\
\hline Meaning & 4723 & 7.10 & 7.67 & 2.28 & 0.00 & 6.00 & 7.67 & 8.67 & 10.00 \\
\hline Accomplishment & 4724 & 7.27 & 7.67 & 1.82 & 0.00 & 6.33 & 7.67 & 8.67 & 10.00 \\
\hline Overall wellbeing & 4724 & 6.99 & 7.44 & 1.79 & 0.00 & 5.94 & 7.44 & 8.31 & 10.00 \\
\hline Negative emotion & 4661 & 4.16 & 4.00 & 2.07 & 0.00 & 2.33 & 4.00 & 5.67 & 10.00 \\
\hline Physical health & 4661 & 7.05 & 7.67 & 2.24 & 0.00 & 5.67 & 7.67 & 8.67 & 10.00 \\
\hline \multicolumn{10}{|l|}{ Age 55-64 } \\
\hline Positive emotion & 2699 & 6.72 & 7.33 & 2.13 & 0.00 & 5.67 & 7.33 & 8.33 & 10.00 \\
\hline Engagement & 2698 & 7.39 & 7.67 & 1.77 & 0.00 & 6.67 & 7.67 & 8.67 & 10.00 \\
\hline Relationships & 2699 & 6.84 & 7.33 & 2.28 & 0.00 & 5.33 & 7.33 & 8.67 & 10.00 \\
\hline Meaning & 2698 & 7.33 & 8.00 & 2.25 & 0.00 & 6.33 & 8.00 & 9.00 & 10.00 \\
\hline Accomplishment & 2698 & 7.42 & 8.00 & 1.77 & 0.00 & 6.67 & 8.00 & 8.67 & 10.00 \\
\hline Overall wellbeing & 2699 & 7.13 & 7.63 & 1.76 & 0.00 & 6.19 & 7.63 & 8.44 & 10.00 \\
\hline Negative emotion & 2665 & 3.92 & 3.67 & 2.08 & 0.00 & 2.00 & 3.67 & 5.33 & 10.00 \\
\hline Physical health & 2665 & 7.24 & 8.00 & 2.18 & 0.00 & 6.00 & 8.00 & 9.00 & 10.00 \\
\hline \multicolumn{10}{|l|}{ Age 65+ } \\
\hline Positive emotion & 870 & 6.91 & 7.33 & 2.08 & 0.00 & 6.00 & 7.33 & 8.33 & 10.00 \\
\hline Engagement & 870 & 7.58 & 8.00 & 1.78 & 0.00 & 6.67 & 8.00 & 9.00 & 10.00 \\
\hline Relationships & 870 & 7.03 & 7.67 & 2.25 & 0.00 & 5.67 & 7.67 & 8.67 & 10.00 \\
\hline Meaning & 870 & 7.48 & 8.17 & 2.28 & 0.00 & 6.67 & 8.17 & 9.00 & 10.00 \\
\hline Accomplishment & 870 & 7.56 & 8.00 & 1.72 & 0.00 & 6.67 & 8.00 & 8.67 & 10.00 \\
\hline Overall wellbeing & 870 & 7.30 & 7.81 & 1.77 & 0.00 & 6.44 & 7.81 & 8.63 & 9.94 \\
\hline Negative emotion & 834 & 3.60 & 3.33 & 2.04 & 0.00 & 1.67 & 3.33 & 5.00 & 10.00 \\
\hline Physical health & 834 & 7.51 & 8.00 & 2.15 & 0.33 & 6.33 & 8.00 & 9.00 & 10.00 \\
\hline
\end{tabular}




\begin{tabular}{|c|c|c|c|c|c|c|c|c|c|}
\hline & $\mathbf{N}$ & Mean & Median & SD & Min & 25th & 50th & 75th & Max \\
\hline \multicolumn{10}{|l|}{ Age: Unknown } \\
\hline Positive emotion & 1343 & 6.63 & 7.00 & 1.92 & 0.00 & 5.33 & 7.00 & 8.00 & 10.00 \\
\hline Engagement & 1343 & 7.12 & 7.33 & 1.75 & 0.00 & 6.00 & 7.33 & 8.33 & 10.00 \\
\hline Relationships & 1322 & 6.76 & 7.00 & 2.17 & 0.00 & 5.33 & 7.00 & 8.33 & 10.00 \\
\hline Meaning & 1322 & 6.93 & 7.33 & 2.12 & 0.00 & 5.67 & 7.33 & 8.50 & 10.00 \\
\hline Accomplishment & 1343 & 6.94 & 7.33 & 1.86 & 0.00 & 6.00 & 7.33 & 8.33 & 10.00 \\
\hline Overall wellbeing & 1343 & 6.87 & 7.22 & 1.66 & 0.00 & 5.83 & 7.22 & 8.11 & 10.00 \\
\hline Negative emotion & 1341 & 4.76 & 4.67 & 2.10 & 0.00 & 3.33 & 4.67 & 6.33 & 10.00 \\
\hline Physical health & 1337 & 6.91 & 7.33 & 2.14 & 0.00 & 5.67 & 7.33 & 8.67 & 10.00 \\
\hline \multicolumn{10}{|l|}{ United States } \\
\hline Positive emotion & 12296 & 6.83 & 7.33 & 1.98 & 0.00 & 5.67 & 7.33 & 8.33 & 10.00 \\
\hline Engagement & 12293 & 7.45 & 7.67 & 1.68 & 0.00 & 6.67 & 7.67 & 8.67 & 10.00 \\
\hline Relationships & 12296 & 7.02 & 7.67 & 2.17 & 0.00 & 5.67 & 7.67 & 8.67 & 10.00 \\
\hline Meaning & 12290 & 7.28 & 8.00 & 2.19 & 0.00 & 6.33 & 8.00 & 9.00 & 10.00 \\
\hline Accomplishment & 12293 & 7.50 & 8.00 & 1.74 & 0.00 & 6.67 & 8.00 & 8.67 & 10.00 \\
\hline Overall wellbeing & 12296 & 7.21 & 7.63 & 1.66 & 0.00 & 6.38 & 7.63 & 8.42 & 10.00 \\
\hline Negative emotion & 12011 & 4.48 & 4.33 & 2.11 & 0.00 & 3.00 & 4.33 & 6.00 & 10.00 \\
\hline Physical health & 12011 & 6.95 & 7.67 & 2.23 & 0.00 & 5.67 & 7.67 & 8.67 & 10.00 \\
\hline \multicolumn{10}{|l|}{ United Kingdom } \\
\hline Positive emotion & 1479 & 6.57 & 7.00 & 1.99 & 0.00 & 5.33 & 7.00 & 8.00 & 10.00 \\
\hline Engagement & 1479 & 7.23 & 7.67 & 1.73 & 0.67 & 6.33 & 7.67 & 8.33 & 10.00 \\
\hline Relationships & 1479 & 6.82 & 7.33 & 2.16 & 0.00 & 5.33 & 7.33 & 8.67 & 10.00 \\
\hline Meaning & 1479 & 6.90 & 7.33 & 2.22 & 0.00 & 6.00 & 7.33 & 8.67 & 10.00 \\
\hline Accomplishment & 1479 & 7.13 & 7.67 & 1.75 & 0.33 & 6.33 & 7.67 & 8.33 & 10.00 \\
\hline Overall wellbeing & 1479 & 6.92 & 7.25 & 1.67 & 0.69 & 6.06 & 7.25 & 8.13 & 10.00 \\
\hline Negative emotion & 1479 & 4.49 & 4.67 & 2.01 & 0.00 & 3.00 & 4.67 & 6.00 & 10.00 \\
\hline Physical health & 1479 & 6.81 & 7.33 & 2.25 & 0.00 & 5.33 & 7.33 & 8.67 & 10.00 \\
\hline \multicolumn{10}{|l|}{ Canada } \\
\hline Positive emotion & 1536 & 6.69 & 7.00 & 1.97 & 0.00 & 5.67 & 7.00 & 8.00 & 10.00 \\
\hline Engagement & 1536 & 7.39 & 7.67 & 1.69 & 0.00 & 6.67 & 7.67 & 8.67 & 10.00 \\
\hline Relationships & 1536 & 6.90 & 7.33 & 2.13 & 0.00 & 5.67 & 7.33 & 8.67 & 10.00 \\
\hline Meaning & 1536 & 6.95 & 7.33 & 2.19 & 0.00 & 5.67 & 7.33 & 8.67 & 10.00 \\
\hline Accomplishment & 1536 & 7.27 & 7.67 & 1.76 & 0.00 & 6.33 & 7.67 & 8.67 & 10.00 \\
\hline Overall wellbeing & 1536 & 7.03 & 7.44 & 1.65 & 0.00 & 6.13 & 7.44 & 8.25 & 10.00 \\
\hline Negative emotion & 1536 & 4.57 & 4.67 & 1.99 & 0.00 & 3.00 & 4.67 & 6.00 & 10.00 \\
\hline Physical health & 1536 & 6.84 & 7.33 & 2.23 & 0.00 & 5.33 & 7.33 & 8.67 & 10.00 \\
\hline \multicolumn{10}{|c|}{ Australia/New Zealand } \\
\hline Positive emotion & 2593 & 6.68 & 7.00 & 1.94 & 0.00 & 5.67 & 7.00 & 8.00 & 10.00 \\
\hline Engagement & 2593 & 7.29 & 7.67 & 1.68 & 0.67 & 6.33 & 7.67 & 8.33 & 10.00 \\
\hline Relationships & 2593 & 6.90 & 7.33 & 2.12 & 0.00 & 5.67 & 7.33 & 8.33 & 10.00 \\
\hline Meaning & 2593 & 7.05 & 7.67 & 2.12 & 0.00 & 6.00 & 7.67 & 8.67 & 10.00 \\
\hline Accomplishment & 2593 & 7.26 & 7.67 & 1.74 & 0.00 & 6.33 & 7.67 & 8.33 & 10.00 \\
\hline Overall wellbeing & 2593 & 7.03 & 7.44 & 1.62 & 0.69 & 6.19 & 7.44 & 8.19 & 10.00 \\
\hline Negative emotion & 2593 & 4.33 & 4.33 & 1.99 & 0.00 & 2.67 & 4.33 & 5.67 & 10.00 \\
\hline Physical health & 2593 & 6.79 & 7.33 & 2.23 & 0.00 & 5.33 & 7.33 & 8.33 & 10.00 \\
\hline \multicolumn{10}{|l|}{ Western Europe } \\
\hline Positive emotion & 919 & 6.82 & 7.33 & 1.79 & 0.00 & 6.00 & 7.33 & 8.00 & 10.00 \\
\hline Engagement & 919 & 7.16 & 7.33 & 1.67 & 0.00 & 6.33 & 7.33 & 8.33 & 10.00 \\
\hline Relationships & 919 & 6.95 & 7.33 & 2.04 & 0.00 & 6.00 & 7.33 & 8.33 & 10.00 \\
\hline Meaning & 919 & 6.88 & 7.33 & 2.06 & 0.00 & 6.00 & 7.33 & 8.33 & 10.00 \\
\hline Accomplishment & 919 & 7.23 & 7.67 & 1.57 & 0.33 & 6.33 & 7.67 & 8.33 & 10.00 \\
\hline
\end{tabular}




\begin{tabular}{|c|c|c|c|c|c|c|c|c|c|}
\hline & $\mathbf{N}$ & Mean & Median & SD & Min & 25th & 50th & 75th & Max \\
\hline Overall wellbeing & 919 & 7.01 & 7.31 & 1.50 & 0.88 & 6.19 & 7.31 & 8.06 & 10.00 \\
\hline Negative emotion & 919 & 4.27 & 4.00 & 2.09 & 0.00 & 2.67 & 4.00 & 5.67 & 10.00 \\
\hline Physical health & 919 & 7.21 & 7.67 & 1.99 & 0.00 & 6.33 & 7.67 & 8.67 & 10.00 \\
\hline \multicolumn{10}{|l|}{ Northern Europe } \\
\hline Positive emotion & 359 & 6.70 & 7.00 & 1.89 & 0.00 & 5.67 & 7.00 & 8.00 & 9.33 \\
\hline Engagement & 359 & 7.23 & 7.67 & 1.65 & 0.33 & 6.33 & 7.67 & 8.67 & 10.00 \\
\hline Relationships & 359 & 7.12 & 7.67 & 2.10 & 0.00 & 6.00 & 7.67 & 8.67 & 10.00 \\
\hline Meaning & 359 & 7.13 & 7.67 & 2.15 & 0.00 & 6.00 & 7.67 & 8.67 & 10.00 \\
\hline Accomplishment & 359 & 7.25 & 7.67 & 1.74 & 0.67 & 6.33 & 7.67 & 8.67 & 10.00 \\
\hline Overall wellbeing & 359 & 7.07 & 7.44 & 1.56 & 0.19 & 6.31 & 7.44 & 8.19 & 9.56 \\
\hline Negative emotion & 359 & 3.95 & 3.67 & 1.95 & 0.00 & 2.33 & 3.67 & 5.33 & 9.67 \\
\hline Physical health & 359 & 7.22 & 7.67 & 2.12 & 0.00 & 6.00 & 7.67 & 8.67 & 10.00 \\
\hline \multicolumn{10}{|c|}{ Eastern Europe/Russia } \\
\hline Positive emotion & 279 & 6.65 & 7.00 & 2.03 & 1.00 & 5.33 & 7.00 & 8.00 & 10.00 \\
\hline Engagement & 279 & 7.16 & 7.33 & 1.70 & 1.67 & 6.33 & 7.33 & 8.33 & 10.00 \\
\hline Relationships & 279 & 6.86 & 7.33 & 2.16 & 0.00 & 5.33 & 7.33 & 8.33 & 10.00 \\
\hline Meaning & 279 & 6.61 & 7.00 & 2.47 & 0.00 & 5.33 & 7.00 & 8.67 & 10.00 \\
\hline Accomplishment & 279 & 7.03 & 7.33 & 1.86 & 1.00 & 6.00 & 7.33 & 8.33 & 10.00 \\
\hline Overall wellbeing & 279 & 6.86 & 7.25 & 1.71 & 2.25 & 5.69 & 7.25 & 8.06 & 10.00 \\
\hline Negative emotion & 279 & 4.46 & 4.33 & 2.15 & 0.33 & 2.67 & 4.33 & 6.00 & 9.33 \\
\hline Physical health & 279 & 7.20 & 7.67 & 2.05 & 1.00 & 6.00 & 7.67 & 8.67 & 10.00 \\
\hline \multicolumn{10}{|l|}{ Middle East } \\
\hline Positive emotion & 179 & 6.75 & 7.00 & 1.85 & 0.00 & 5.67 & 7.00 & 8.33 & 10.00 \\
\hline Engagement & 179 & 7.16 & 7.33 & 1.87 & 0.00 & 6.33 & 7.33 & 8.67 & 10.00 \\
\hline Relationships & 179 & 6.69 & 7.33 & 2.18 & 0.00 & 5.33 & 7.33 & 8.33 & 10.00 \\
\hline Meaning & 179 & 6.99 & 7.33 & 2.00 & 0.00 & 6.00 & 7.33 & 8.33 & 10.00 \\
\hline Accomplishment & 179 & 7.04 & 7.67 & 1.85 & 0.00 & 6.33 & 7.67 & 8.33 & 10.00 \\
\hline Overall wellbeing & 179 & 6.92 & 7.25 & 1.60 & 0.00 & 5.94 & 7.25 & 8.13 & 9.94 \\
\hline Negative emotion & 179 & 4.81 & 4.67 & 2.17 & 0.00 & 3.33 & 4.67 & 6.33 & 10.00 \\
\hline Physical health & 179 & 7.06 & 7.67 & 2.24 & 0.00 & 5.67 & 7.67 & 8.67 & 10.00 \\
\hline \multicolumn{10}{|c|}{ Mexico/Central America } \\
\hline Positive emotion & 310 & 7.85 & 8.33 & 1.61 & 0.67 & 7.00 & 8.33 & 9.00 & 10.00 \\
\hline Engagement & 310 & 8.13 & 8.33 & 1.26 & 2.00 & 7.33 & 8.33 & 9.00 & 10.00 \\
\hline Relationships & 310 & 7.83 & 8.33 & 1.76 & 1.00 & 7.25 & 8.33 & 9.00 & 10.00 \\
\hline Meaning & 310 & 7.94 & 8.33 & 1.77 & 0.67 & 7.33 & 8.33 & 9.08 & 10.00 \\
\hline Accomplishment & 310 & 7.91 & 8.33 & 1.47 & 1.33 & 7.33 & 8.33 & 9.00 & 10.00 \\
\hline Overall wellbeing & 310 & 7.93 & 8.25 & 1.29 & 2.31 & 7.38 & 8.25 & 8.81 & 10.00 \\
\hline Negative emotion & 310 & 4.67 & 4.67 & 2.21 & 0.33 & 3.00 & 4.67 & 6.33 & 9.33 \\
\hline Physical health & 310 & 7.80 & 8.33 & 1.81 & 0.67 & 7.00 & 8.33 & 9.00 & 10.00 \\
\hline \multicolumn{10}{|l|}{ South America } \\
\hline Positive emotion & 275 & 7.03 & 7.33 & 1.78 & 1.00 & 6.00 & 7.33 & 8.33 & 10.00 \\
\hline Engagement & 275 & 7.44 & 7.67 & 1.56 & 1.33 & 6.67 & 7.67 & 8.33 & 10.00 \\
\hline Relationships & 275 & 7.08 & 7.33 & 1.95 & 1.00 & 6.00 & 7.33 & 8.33 & 10.00 \\
\hline Meaning & 275 & 7.28 & 7.67 & 2.04 & 0.33 & 6.00 & 7.67 & 8.67 & 10.00 \\
\hline Accomplishment & 275 & 7.30 & 7.67 & 1.75 & 0.67 & 6.33 & 7.67 & 8.67 & 10.00 \\
\hline Overall wellbeing & 275 & 7.22 & 7.56 & 1.49 & 1.06 & 6.56 & 7.56 & 8.38 & 10.00 \\
\hline Negative emotion & 275 & 4.93 & 5.00 & 1.99 & 0.00 & 3.67 & 5.00 & 6.33 & 10.00 \\
\hline Physical health & 275 & 7.47 & 8.00 & 2.06 & 0.67 & 6.33 & 8.00 & 9.00 & 10.00 \\
\hline \multicolumn{10}{|l|}{ Pacific Islands } \\
\hline Positive emotion & 113 & 7.70 & 7.67 & 1.53 & 0.33 & 7.00 & 7.67 & 8.67 & 10.00 \\
\hline Engagement & 113 & 7.77 & 8.00 & 1.30 & 3.33 & 7.00 & 8.00 & 8.67 & 10.00 \\
\hline
\end{tabular}




\begin{tabular}{|c|c|c|c|c|c|c|c|c|c|}
\hline & $\mathbf{N}$ & Mean & Median & SD & Min & 25th & 50th & 75th & Max \\
\hline Relationships & 113 & 7.51 & 7.67 & 1.69 & 0.33 & 6.67 & 7.67 & 8.67 & 10.00 \\
\hline Meaning & 113 & 7.74 & 8.00 & 1.81 & 0.00 & 7.00 & 8.00 & 9.00 & 10.00 \\
\hline Accomplishment & 113 & 7.63 & 8.00 & 1.62 & 0.67 & 7.00 & 8.00 & 8.67 & 10.00 \\
\hline Overall wellbeing & 113 & 7.68 & 7.88 & 1.34 & 1.06 & 7.13 & 7.88 & 8.56 & 10.00 \\
\hline Negative emotion & 113 & 4.96 & 4.67 & 2.22 & 0.00 & 3.33 & 4.67 & 6.67 & 10.00 \\
\hline Physical health & 113 & 7.31 & 7.67 & 1.85 & 1.00 & 6.67 & 7.67 & 8.67 & 10.00 \\
\hline \multicolumn{10}{|l|}{ Caribbean } \\
\hline Positive emotion & 60 & 7.45 & 7.67 & 1.61 & 2.33 & 6.42 & 7.67 & 8.67 & 10.00 \\
\hline Engagement & 60 & 7.73 & 7.67 & 1.30 & 4.67 & 7.00 & 7.67 & 8.67 & 10.00 \\
\hline Relationships & 60 & 7.26 & 7.67 & 1.96 & 2.33 & 6.33 & 7.67 & 8.67 & 10.00 \\
\hline Meaning & 60 & 7.67 & 8.00 & 1.77 & 2.33 & 7.00 & 8.00 & 9.00 & 10.00 \\
\hline Accomplishment & 60 & 7.66 & 8.00 & 1.33 & 3.67 & 7.08 & 8.00 & 8.59 & 9.67 \\
\hline Overall wellbeing & 60 & 7.56 & 7.72 & 1.37 & 3.63 & 6.95 & 7.72 & 8.55 & 9.88 \\
\hline Negative emotion & 60 & 4.89 & 5.17 & 2.13 & 1.00 & 3.00 & 5.17 & 6.59 & 8.67 \\
\hline Physical health & 60 & 7.36 & 7.84 & 1.96 & 1.00 & 6.33 & 7.84 & 8.67 & 10.00 \\
\hline \multicolumn{10}{|l|}{ Mediterranean } \\
\hline Positive emotion & 91 & 6.65 & 7.00 & 1.83 & 1.00 & 5.67 & 7.00 & 8.00 & 9.67 \\
\hline Engagement & 91 & 7.04 & 7.33 & 1.75 & 1.00 & 6.00 & 7.33 & 8.33 & 10.00 \\
\hline Relationships & 91 & 6.66 & 7.00 & 2.18 & 0.33 & 5.67 & 7.00 & 8.33 & 10.00 \\
\hline Meaning & 91 & 6.81 & 7.33 & 2.12 & 0.33 & 5.67 & 7.33 & 8.33 & 10.00 \\
\hline Accomplishment & 91 & 7.19 & 7.67 & 1.76 & 1.00 & 6.00 & 7.67 & 8.33 & 10.00 \\
\hline Overall wellbeing & 91 & 6.87 & 7.13 & 1.54 & 2.00 & 6.13 & 7.13 & 8.00 & 9.81 \\
\hline Negative emotion & 91 & 5.18 & 5.00 & 2.14 & 1.00 & 3.67 & 5.00 & 6.67 & 10.00 \\
\hline Physical health & 91 & 7.47 & 8.00 & 1.86 & 0.67 & 6.67 & 8.00 & 9.00 & 10.00 \\
\hline \multicolumn{10}{|l|}{ Africa } \\
\hline Positive emotion & 269 & 7.03 & 7.67 & 1.85 & 0.00 & 6.33 & 7.67 & 8.33 & 10.00 \\
\hline Engagement & 269 & 7.42 & 7.67 & 1.56 & 0.00 & 6.67 & 7.67 & 8.67 & 10.00 \\
\hline Relationships & 269 & 7.14 & 7.67 & 2.10 & 0.00 & 6.17 & 7.67 & 8.67 & 10.00 \\
\hline Meaning & 269 & 7.39 & 8.00 & 2.06 & 0.00 & 6.50 & 8.00 & 9.00 & 10.00 \\
\hline Accomplishment & 269 & 7.41 & 8.00 & 1.81 & 0.00 & 6.67 & 8.00 & 8.67 & 10.00 \\
\hline Overall wellbeing & 269 & 7.27 & 7.75 & 1.67 & 0.00 & 6.56 & 7.75 & 8.44 & 10.00 \\
\hline Negative emotion & 269 & 4.39 & 4.67 & 1.93 & 0.00 & 3.00 & 4.67 & 5.67 & 8.67 \\
\hline Physical health & 269 & 7.09 & 7.67 & 2.21 & 0.00 & 6.00 & 7.67 & 8.67 & 10.00 \\
\hline \multicolumn{10}{|c|}{ India/Southeastern Asia } \\
\hline Positive emotion & 918 & 7.02 & 7.33 & 1.60 & 0.33 & 6.33 & 7.33 & 8.00 & 10.00 \\
\hline Engagement & 918 & 7.15 & 7.33 & 1.49 & 0.33 & 6.33 & 7.33 & 8.00 & 10.00 \\
\hline Relationships & 918 & 7.09 & 7.33 & 1.81 & 0.00 & 6.00 & 7.33 & 8.33 & 10.00 \\
\hline Meaning & 918 & 7.07 & 7.33 & 1.74 & 0.00 & 6.00 & 7.33 & 8.33 & 10.00 \\
\hline Accomplishment & 918 & 7.09 & 7.33 & 1.52 & 0.33 & 6.33 & 7.33 & 8.00 & 10.00 \\
\hline Overall wellbeing & 918 & 7.10 & 7.25 & 1.34 & 1.31 & 6.38 & 7.25 & 8.00 & 10.00 \\
\hline Negative emotion & 918 & 5.05 & 5.00 & 1.97 & 0.00 & 3.67 & 5.00 & 6.67 & 10.00 \\
\hline Physical health & 918 & 6.88 & 7.33 & 1.98 & 0.00 & 5.67 & 7.33 & 8.33 & 10.00 \\
\hline \multicolumn{10}{|l|}{ Asia } \\
\hline Positive emotion & 382 & 6.90 & 7.33 & 1.83 & 0.00 & 6.00 & 7.33 & 8.00 & 10.00 \\
\hline Engagement & 382 & 6.98 & 7.33 & 1.57 & 1.00 & 6.00 & 7.33 & 8.00 & 10.00 \\
\hline Relationships & 382 & 6.77 & 7.00 & 1.93 & 0.00 & 5.67 & 7.00 & 8.00 & 10.00 \\
\hline Meaning & 382 & 6.97 & 7.33 & 2.06 & 0.00 & 6.00 & 7.33 & 8.33 & 10.00 \\
\hline Accomplishment & 382 & 7.06 & 7.33 & 1.77 & 0.67 & 6.25 & 7.33 & 8.33 & 10.00 \\
\hline Overall wellbeing & 382 & 6.95 & 7.31 & 1.54 & 0.75 & 6.13 & 7.31 & 8.00 & 10.00 \\
\hline Negative emotion & 382 & 4.45 & 4.33 & 1.98 & 0.00 & 3.00 & 4.33 & 5.67 & 10.00 \\
\hline Physical health & 382 & 6.82 & 7.33 & 2.08 & 0.00 & 5.33 & 7.33 & 8.33 & 10.00 \\
\hline
\end{tabular}




\begin{tabular}{lccccccccc}
\hline & N & Mean & Median & SD & Min & 25th & 50th & 75th & Max \\
\hline Country: Unknown & & & & & & & & & \\
$\quad$ Positive emotion & 9907 & 6.42 & 6.67 & 1.98 & 0.00 & 5.33 & 6.67 & 8.00 & 10.00 \\
Engagement & 9907 & 6.96 & 7.33 & 1.75 & 0.00 & 6.00 & 7.33 & 8.33 & 10.00 \\
Relationships & 9882 & 6.70 & 7.00 & 2.17 & 0.00 & 5.33 & 7.00 & 8.33 & 10.00 \\
Meaning & 9879 & 6.80 & 7.33 & 2.19 & 0.00 & 5.67 & 7.33 & 8.33 & 10.00 \\
Accomplishment & 9908 & 6.83 & 7.33 & 1.81 & 0.00 & 5.67 & 7.33 & 8.33 & 10.00 \\
Overall wellbeing & 9908 & 6.74 & 7.06 & 1.67 & 0.00 & 5.69 & 7.06 & 8.00 & 10.00 \\
Negative emotion & 9613 & 4.40 & 4.33 & 2.01 & 0.00 & 3.00 & 4.33 & 6.00 & 10.00 \\
Physical health & 8828 & 6.92 & 7.33 & 2.13 & 0.00 & 5.67 & 7.33 & 8.67 & 10.00 \\
\hline
\end{tabular}

Note. $\mathrm{SD}=$ standard deviation, Min $=$ minimum, $25^{\text {th }}, 50^{\text {th }}, 75^{\text {th }}=$ percentile scores, Max $=$ maximum 